\title{
Atlas of Finnish bats
}

\section{Eeva-Maria Tidenberg (formerly Kyheröinen) ${ }^{1,3, *}$, Ulla-Maija Liukko² \& Torsten Stjernberg ${ }^{1}$}
1) Finnish Museum of Natural History Luomus, P.O. Box 17, Fl-00014 University of Helsinki, Finland ( ${ }^{*}$ corresponding author's e-mail: eeva-maria.tidenberg@helsinki.fi)
2) Finnish Environment Institute (SYKE), Latokartanonkaari 11, FI-00790 Helsinki, Finland
3) Open Science Centre, Jyväskylä University Museum, P.O. Box 35, Fl-40014 University of Jyväskylä, Finland

We dedicate this Atlas of Finnish bats to the memory of Rudolf Lehmann (1955-1985), who in the early 1980s started a new era in bat research in Finland

Received 30 Oct. 2018, final version received 25 Oct. 2019, accepted 30 Oct. 2019

Tidenberg, E.-M., Liukko, U.-M. \& Stjernberg, T. 2019: Atlas of Finnish bats. - Ann. Zool. Fennici 56: $207-250$.

This atlas is based on information in museum collections, literature, databases and unpublished data. In the last 150 years, the number of bat species in Finland increased from six to thirteen. Of these, five are common and regularly breeding (Eptesicus nilssonii, Myotis brandtii, Myotis daubentonii, Myotis mystacinus, Plecotus auritus), and eight rare (Eptesicus serotinus, Myotis dasycneme, Myotis nattereri, Nyctalus noctula, Pipistrellus nathusii, Pipistrellus pipistrellus, Pipistrellus pygmaeus, Vespertilio murinus), of which breeding of two (M. nattereri, P. nathusii) have been confirmed. The total number of records in the study is 11234 , of which 9717 are identified to species. The records are from $940(25 \%) 10-\mathrm{km}^{2}$ squares of Finland's land area. Of the records, 89\% are new (1993-2014). Of the recorded bat species, only Eptesicus nilssonii occurs in each of the 21 biogeographical provinces. A decreasing south-north gradient in species richness and abundance exists which may be related to research efforts that are clearly higher in the south.

\section{Introduction}

Bats are a large and diverse mammalian group inhabiting almost all terrestrial areas of the world (Altringham 2011). According to the Mammal Diversity Database, there are 6399 extant mammal species in the world, of which approximately 20\% (1411) are bats (American Society of Mammalogists 2019). Bats play important roles in ecosystems, being for example pollinators and pest-insect predators (Altringham 2011).
However, many bat species are threatened due to various reasons, ranging from habitat degradation and alteration to light pollution and being killed for food. Of the 1261 species included in the global assessment, $21 \%$ are either threatened (critically endangered, endangered, vulnerable) or nearly threatened (IUCN 2019).

European records comprise 44 bat species (Dietz \& Kiefer 2016). By 2018, 13 bat species were recorded in Finland of which at least 7 also reproduce in Finland: northern 
bat (Eptesicus nilssonii), Brandt's bat (Myotis brandtii), Daubenton's bat (Myotis daubentonii), whiskered bat (Myotis mystacinus), Natterer's bat (Myotis nattereri), brown long-eared bat (Plecotus auritus) and Nathusius' pipistrelle (Pipistrellus nathusii) (Kyheröinen et al. 2014, Kyheröinen \& Hyvärinen 2018). In Finland, bats may be affected by habitat change linked to forestry and land use. Two bat species are on the Finnish Red List: Nathusius' pipistrelle assessed as vulnerable and Natterer's bat assessed as endangered (Liukko et al. 2019).

In Finland, all bat species are strictly protected by national and European Union legislations. Bats have been protected since 1923 (Nature Conservation Act 71/1923 [https://www.finlex.fi/fi/laki/ alkup/1923/19230071]). According to the Nature Conservation Act (1096/1996 [http://www.finlex. fi/en/laki/kaannokset/1996/en19961096]) §39, it is forbidden to kill or capture bats, or to deliberately harm or disturb them particularly during breeding or at sites of significance to their life cycles. The autonomous Alland Islands have their own legislation in which all mammals except game species are protected (Landskapslag om naturvård 1998:82, §14 [http://old.regeringen. ax/.composer/upload/socialomiljo/ff-199882_20140116.pdf]). The regulations arising from the EU Habitats' Directive (Council Directive 92/43/EEC 1992) are implemented in $\$ 49$ of the Nature Conservation Act, prohibiting e.g. destruction and deterioration of breeding and resting sites of the Annex IV species. Article 17 of the EU Habitats Directive requires the EU Member States to report every six years about the progress made with the implementation of the Directive regarding the species listed in the annexes to the Directive. Reporting focused on the evaluation of the conservation status of the habitat types and species included in the Annexes to the Directive. Only northern bat, Daubenton's bat and longeared bat have a favourable conservation status (EEA-ETC/BD 2019). Due to deficient data or occasional occurrences of the species, the conservation status could not be assessed for the rest of the bat species. The Article 17 reporting in 2019 is in the process of publication.

As bats are strictly protected, the environmental authorities need basic data on the occurrence and abundance of the species to take it into account in land use planning, to plan conservation measures and to conduct the obligatory reporting to both the European Union (Habitats Directive) and the Agreement on the Conservation of Populations of European Bats (EUROBATS).

Knowledge of the Finnish bat fauna has recently increased and hence there is an urgent need to update both the species composition and their distribution ranges. This study provides (1) an updated version of the Finnish bat fauna and (2) an atlas of Finnish bats. The atlas is based on available information in the collections of Finnish natural history museums, literature and databases and hitherto unpublished data of researchers, amateurs and general public. Additionally, incomplete maps may stimulate observers to report new records.

\section{Historical overview of the bat fauna of Finland}

During the last 150 years, the species number in Finland rose from 6 to 13 (see Table 1). Lundahl (1852) published the first comprehensive report on the Finnish bat fauna mentioning five species: northern bat, whiskered bat (sensu lato), Daubenton's bat, brown long-eared bat and particolored bat. Malmberg (1872) added one species, Nattererer's bat, and Mela (1882) yet another - the noctule - although it is mentioned in the table not in the text. The Finnish bat fauna comprised the same seven species until the 1970s (Siivonen 1967, 1968, 1972).

Baagøe (1973) studied specimens of Myotis mystacinus (sensu lato) from Finland and discerned Brandt's bat (Myotis brandtii) from the whiskered bat (Myotis mystacinus) (see also Lehmann 1983-1984). In 1982, Lehmann (1983b) reported the first Finnish specimen of Nathusius' pipistrelle. After that, Ingemar Ahlén reported his observation of this species which he made already in 1979 in the Åland Islands (sound-recording, I. Ahlén pers. comm. spring 2007; see HagnerWahlsten \& Kyheröinen 2008).

During the 1990s, the Finnish bat fauna still comprised the above-mentioned nine bat species (Haukkovaara 1993, Stjernberg et al. 1993, Mitchell-Jones 1999). Since 2001, a further four species have been added (see Table 1). 
Lundahl (1852) published comprehensive information on the distribution of five bat species in Finland based on his own collections and observations. Later, Malmberg (later Mela) (1872) and Mela (1882) also published records and reports obtained from the general public in addition to his own observations. These reports concerned specimens in the Finnish Museum of Natural History (University of Helsinki), where the oldest bat specimens date from 1849, and the collection of Societas pro Fauna et Flora Fennica. Subsequently, information on bat distribution presented by Mela (1882) was repeated almost unchanged (e.g., Mela \& Kivirikko 1909, Kivirikko 1940).

The first maps illustrating bats' distribution in Finland concerned three species - whiskered bat (Myotis mystacinus sensu lato), Daubenton's bat and brown long-eared bat — were published in 1956 (Siivonen 1956). Only in 1967 were distribution maps published for all Finnish species (then seven); simultaneously additional six species were recorded in the other Nordic countries (Siivonen 1967, 1968).

Lehmann (1983-1984) published the first map in Finland of the whiskered bat and Brandt's bat distributions. Skarèn (1992) published a distribution map of these two species and added some new records, but the distribution ranges remained mostly unchanged, except for three records of $M$. brandtii from the west coast. The initial map for Natterer's bat was published by Stjernberg (1996), and later updated by Stjernberg (1998) and Siivonen and Wermundsen (2008c). Siivonen and Wermundsen (2003a) had published the first distribution map of Nathusius' pipistrelle, which they updated in 2004 (Wermundsen \& Siivonen 2004); the map of the common pipistrelle was updated by Wermundsen and Siivonen (2004).

In 1993, the first two atlases of all Finnish bats (then nine species) were published (Haukkovaara 1993, Stjernberg et al. 1993). Data from these two atlases were included in the Atlas of European Mammals (Mitchell-Jones et al. 1999). We produced distributions maps required by Article 17 of the Habitats Directive using the data (or part of it) of this study: in 2007 for 11 bat species, and in 2013 for all 13 bat species recorded in Finland (EEA-ETC/BD 2019, Kyheröinen et al. 2013).

\section{Material and methods}

\section{Data}

We divided the data sources into four categories: literature, databases, notifications and museum specimens (Table 2). Only reliable bat records including sufficient information on location and date were included in this atlas. Regarding

Table 1. First records of bat species in Finland. $\mathrm{MZH}=$ collections of the Finnish Museum of Natural History Luomus.

\begin{tabular}{lll}
\hline Species & $\begin{array}{c}\text { Year of first } \\
\text { record }\end{array}$ & Source \\
\hline Eptesicus nilssonii (Keyserling \& Blasius, 1839) & 1795 & Radloff (1795) \\
Myotis mystacinus sensu lato (Kuhl, 1817) & 1851 & Lundahl (1852) \\
Myotis mystacinus sensu stricto (Kuhl, 1817) & 1921 & MZH \\
Myotis brandtii (Eversmann, 1845) & 1861 & MZH \\
Myotis daubentonii (Kuhl, 1817) & 1849 & MZH \\
Plecotus auritus (Linnaeus, 1758) & 1795 & Radloff (1795) \\
Vespertilio murinus (Linnaeus, 1758) & 1834 & Lundahl (1852) \\
Myotis nattereri (Kuhl, 1817) & 1849 & MZH \\
Nyctalus noctula (Schreber, 1774) & 1881 & MZH \\
Pipistrellus nathusii (Keyserling \& Blasius, 1893) & 1979 & Pers. comm. by Ingemar Ahlén to the third \\
& & author, see Hagner-Wahlsten \& Kyheröinen \\
Pipistrellus pipistrellus sensu stricto (Schreber, 1774) & 2001 & 2008) \\
Myotis dasycneme (Leach, 1825) & 2002 & Salovaara (2001) \\
Pipistrellus pygmaeus (Leach, 1825) & 2007 & Salovanen \& Wermundsen (2003b) \\
Eptesicus serotinus (Schreber, 1774) & 2008 & Lappalainen (2008) \\
\hline
\end{tabular}


reliability, only records provided by observers considered skilled experts, or thoroughly documented observations (e.g. incl. photo or recording) of a specimen were accepted.

Nearly half of the records (44\%) were obtained from literature (e.g., articles, books, reports). Of the 400 sources, approximately 300 (marked with an asterisks in the references) contained information on bats with sufficient spatial accuracy.

Many records (28\%) were from databases with open or restricted access (Table 2). Due to inexact information or unconfirmed species identification only $30 \%-60 \%$ of data from the open access databases was included in this study.

Researchers, professional bat surveyors and skilled bat amateurs provided survey data or random observations (18\%), including some well-documented observations from the general public. The data were either given directly to the authors of this atlas or to the Finnish Museum of Natural History. Data were also collected from the internet. The authors' own observations are also included.
A lesser yet important source, accounting for $10 \%$ of sources, were specimen records in collections of the Finnish Museum of Natural History (Helsinki) and in the regional museums of natural history in Oulu, Turku, Kuopio, Forssa, Iisalmi and Joensuu.

The earliest existing bat records date from the first half of the 19th century (for record numbers see Fig. 1). Observations made between 2001 and 2014 (approximately 11000 ) accounted for $86 \%$ of the data.

\section{Geographical accuracy}

In the original sources, locations of bat observations were given with sufficient accurcy. Of the available bat records, approximately $86 \%$ included information on the species observed (including Myotis mystacinus/brandtii), and either exact location or information allowing for pinpointing the location with an accuracy of $1-1000 \mathrm{~m}$, that is, within a $10-\mathrm{km}^{2}$ grid square. In about $11 \%$ of records, locations were given

Table 2. Data sources and their description.

\begin{tabular}{|c|c|c|}
\hline Source & Accessed & Type \\
\hline Literature & $\begin{array}{l}\text { mainly before } 2012 \text { (some } \\
\text { additional before } 2014 \text { ) }\end{array}$ & Articles and reports and other literature (see References) \\
\hline \multirow[t]{3}{*}{ Databases } & before spring 2012 & $\begin{array}{l}\text { Observation database of the Finnish Chiropterological } \\
\text { Society (not in use anymore) [open access, } 60 \% \text { of the } \\
\text { data included]. }\end{array}$ \\
\hline & before spring 2012 & $\begin{array}{l}\text { Observation database Hatikka of the Finnish Museum of } \\
\text { Natural History (FinBIF 2019) [open access, } 32 \% \text { of the } \\
\text { data included]. }\end{array}$ \\
\hline & before 2012 & $\begin{array}{l}\text { Ringing database of the Finnish Museum of Natural History } \\
\text { (Ringing Centre) [restricted access, data from 2004-2011]. }\end{array}$ \\
\hline \multirow[t]{2}{*}{ Museum specimens } & before summer 2011 & $\begin{array}{l}\text { Database of the vertebrate of collection of the Finnish } \\
\text { Museum of Natural History. }\end{array}$ \\
\hline & before 2007 & $\begin{array}{l}\text { Regional museums of natural history in Oulu, Turku, } \\
\text { Kuopio, Forssa, lisalmi, Joensuu. }\end{array}$ \\
\hline \multirow[t]{4}{*}{ Notifications } & before 2012 & $\begin{array}{l}\text { Archives of notifications given to the Finnish Museum } \\
\text { Natural History, random observations. }\end{array}$ \\
\hline & before 2014 & $\begin{array}{l}\text { Notifications of unpublished results and survey data from } \\
\text { researchers, professional surveyors and skilled bat } \\
\text { amateurs, including the authors themselves } \\
\text { (see Acknowledgements). }\end{array}$ \\
\hline & before autumn 2012 & $\begin{array}{l}\text { Archives and surveillance data of hibernation sites } \\
\text { (Finnish Museum of Natural History). }\end{array}$ \\
\hline & 2010 & $\begin{array}{l}\text { Bat survey in eastern Finland (Finnish Museum of Natural } \\
\text { History). }\end{array}$ \\
\hline
\end{tabular}


Fig. 1. Numbers of bat records (incl. unidentified bat records) per decade; for the 19th century, however, records are presented per five decades. The last period comprises only five years. Due to inexact date information, 319 records are not included.

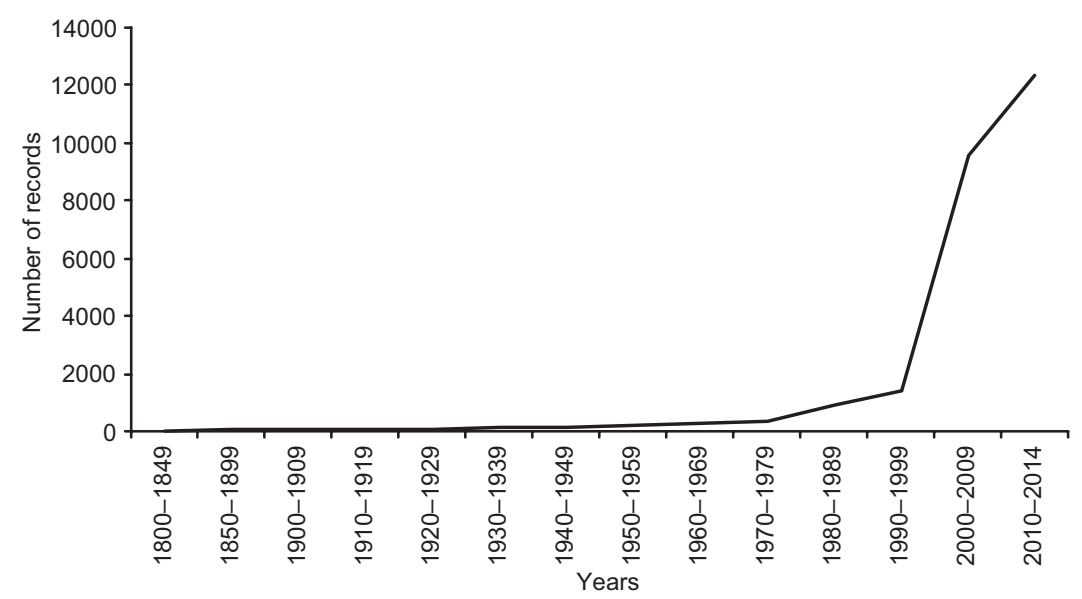

with a 10-km accuracy, allowing for allocation into a correct grid square, particularly in the case when an observer reported the record with an accuracy of $10 \mathrm{~km}^{2}$. Inaccuracies in location could have resulted in records being placed in squares neighbouring the correct ones. We, however, consider the effects of such errors on distributions negligible.

Location accuracies could also be less than $10 \mathrm{~km}$. For example, if the municipality where the observation was made was reported, the chosen locality was the geographical centre of the municipality. The resulting accuracy was within a few $10-\mathrm{km}^{2}$ squares. Such potentially inaccurate records accounted for $3 \%$ of the data (297 bat records identified at the species level).

\section{Number of records and squares}

In this study, an observation of one or more individuals of a certain species at one site, on one occasion was considered one record. Thus, even hundreds of recordings of one species by an automatically recording device produced during one night were included as one record. For common species, especially the northern bat, adjacent and concurrent observations (distance usually $<1 \mathrm{~km}$ ) were usually pooled into one record. Pooling of some data was due to time or space inaccuracies. For these reasons, the numbers of records are not directly comparable between species or areas.

The data consist of 12663 records, of which in 9717 of the cases the species was indentified
(Table 3). Distinguishing between the whiskered bat and Brandt's bat is usually impossible unless examined by hand. Hence, in many cases we did not separate the two species and presented them together (Myotis mystacinus/brandtii or whiskered bat/Brandt's bat) in the tables and figures. As a result, a total of 11234 records were used to prepare the maps. Records of unidentified bats (Myotis sp., Chiroptera sp., etc.) were included in the map of all records (Fig. 2), but excluded from further analysis. Approximately $380010-\mathrm{km}^{2}$ squares cover the total land area of Finland; records of bats indentifed to the species level were from 940 of them.

The data were divided into two temporal categories (Table 3). Records from surveys carried out before 1993 (11\%; Haukkovaara 1993, Stjernberg et al. 1993, Mitchell-Jones et al. 1999) were considered old and observations from 1993 and onwards (89\%) were considered new. Of the total of $94010-\mathrm{km}^{2}$ squares, 395 and 776 include old and new records, respectively, with 231 squares including both.

\section{Observation types}

We divided the records into three categories according to the observation method (Fig. 3). The method of identification affects the credibility of an observation. Bats were identified (1) through direct examination (by hand) (e.g., dead individuals or individuals caught for ringing); (2) acoustically with a detector or a detector and 
a recorder; or (3) visually (when resting, hibernating, from photographs, and in some cases even when flying). About half of the records were acoustical detector observations (54\%), one third include direct identification (33\%), and only $7 \%$ of the accepted records were based on visual observations. In case of $5 \%$ of the records, the identification method could not be determined. These records originated from databases (Table 2) without information on the observation types. Despite of the lack of the observation type these records were, however, considered reliable based on the observer's experience and other information included.

\section{Distribution of bat species}

\section{Occurrence in biogeographical provinces}

There are 21 biogeographical provinces in Finland (Fig. 4 and Table 4; also Heikinheimo \& Raatikainen 1971, 1981, Ulvinen 1980). As expected, species richness and abundance, in terms of record numbers, based on our bat data are highest in the provinces of the southern mainland. More than half of the identified bat records are from the southernmost provinces of Nylandia and Regio Aboensis. By including the records from Tavastia Australis, the proportion increases to $70 \%$. The decreasing south-to-north gradient in the present data of both species richness and abundance is a result of the higher research effort in some regions of the south than the north, but it may also truly exist.

The only species recorded in every province is the northern bat, being the only bat species observed in the four northernmost provinces. Other widespread species which occur in ten or more provinces are Brandt's bat, Daubenton's bat, the long-eared bat and, surprisingly, the noctule and Nathusius' pipistrelle. The last two species are notably less abundant, with fewer records, than the other above-mentioned species. The apparent low number of recorded bat species in the province of Alandia is probably due

Table 3. Total numbers of bat records and $10-\mathrm{km}^{2}$ squares with bat records in Finland. Records from before 1993 are considered old, and those from 1993 and onwards are considered new. Contribution of new squares to total coverage (last column) was calculated as follows: $(b-a) / b \times 100$.

\begin{tabular}{|c|c|c|c|c|c|c|c|}
\hline \multirow[t]{2}{*}{ Species } & \multicolumn{3}{|c|}{ Number of records } & \multicolumn{3}{|c|}{ Number of squares } & \multirow{2}{*}{$\begin{array}{c}\text { Contribution } \\
\text { of new } \\
\text { squares } \\
\text { to total } \\
\text { coverage }(\%)\end{array}$} \\
\hline & total & $\begin{array}{c}\text { old } \\
\text { (before } \\
\text { 1993) }\end{array}$ & $\begin{array}{c}\text { new } \\
\text { (1993 and } \\
\text { onwards) }\end{array}$ & $\begin{array}{l}\text { with old } \\
\text { records }{ }^{1} \\
\text { (a) }\end{array}$ & $\begin{array}{l}\text { with new } \\
\text { records }\end{array}$ & $\begin{array}{l}\text { with old } \\
\text { and/or new } \\
\text { records } \\
\text { (b) }\end{array}$ & \\
\hline Eptesicus nilssonii & 5107 & 647 & 4460 & 280 & 547 & 691 & 59.5 \\
\hline Eptesicus serotinus & 4 & 0 & 4 & 0 & 4 & 4 & 100 \\
\hline Myotis brandtii & 645 & 131 & 514 & 55 & 82 & 127 & 56.7 \\
\hline Myotis dasycneme & 4 & 0 & 4 & 0 & 1 & 1 & 100 \\
\hline Myotis daubentonii & 2556 & 285 & 2271 & 118 & 251 & 325 & 63.7 \\
\hline Myotis mystacinus & 189 & 43 & 146 & 21 & 53 & 70 & 70.0 \\
\hline Myotis nattereri & 31 & 8 & 23 & 7 & 8 & 14 & 50.0 \\
\hline Nyctalus noctula & 152 & 52 & 100 & 36 & 67 & 92 & 60.9 \\
\hline Pipistrellus nathusii & 232 & 5 & 227 & 5 & 97 & 99 & 94.9 \\
\hline Pipistrellus pipistrellus & 37 & 0 & 37 & 0 & 25 & 25 & 100 \\
\hline Pipistrellus pygmaeus & 14 & 0 & 14 & 0 & 12 & 12 & 100 \\
\hline Plecotus auritus & 718 & 127 & 591 & 88 & 126 & 182 & 51.6 \\
\hline Vespertilio murinus & 28 & 3 & 25 & 3 & 19 & 21 & 85.7 \\
\hline Myotis mystacinus/brandtii & 1517 & 66 & 1451 & 42 & 194 & 222 & 81.1 \\
\hline Identified total & 11234 & & & & & & \\
\hline Myotis sp. & 821 & 7 & 814 & - & - & & \\
\hline Pipistrellus sp. & 4 & 0 & 4 & - & - & & \\
\hline Chiroptera sp. & 604 & 29 & 575 & - & - & & \\
\hline Total & 12663 & 1403 & 11260 & & & & \\
\hline
\end{tabular}

\footnotetext{
1) may also include new records, ${ }^{2)}$ may also include old records.
} 
Fig. 2. Bat records in

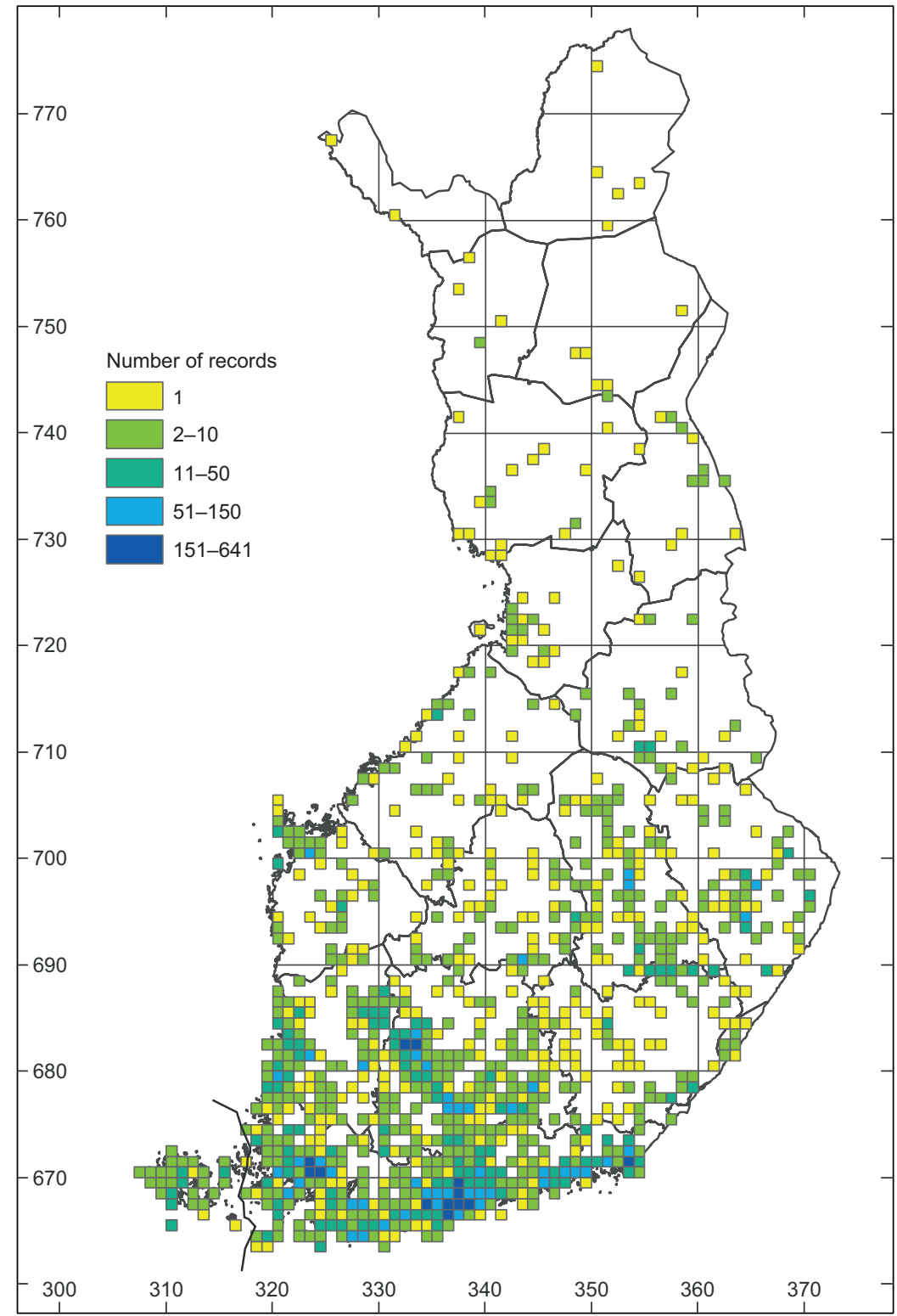
in $10-\mathrm{km}^{2}$ squares (incl. records of unidentified bats). The numbers along axes are coordinates according to the Finnish Uniform Coordinate System (Grid27E).

to the lower research activity there compared with that in the other Finnish southern provinces. There is no province where all species of Finnish bats were observed.

\section{Species accounts and distribution maps}

Species are presented in alphabetical order according to the scientific name. Data on species their global distribution and distribution in Finland as well as information on species' abundance, status in Finland and habitat use are provided.

The English, Finnish and Swedish vernacular names follow the Common Names of European Bats (Lina 2016); the former vernacular name in Swedish is presented in parentheses.

Records of the bat species are shown in $10-\mathrm{km}^{2}$ squares of the Finnish Uniform Coordinate System (Grid27E). Squares coded as new records may also include old ones. Contours of the biogeographical provinces are also in each map. 


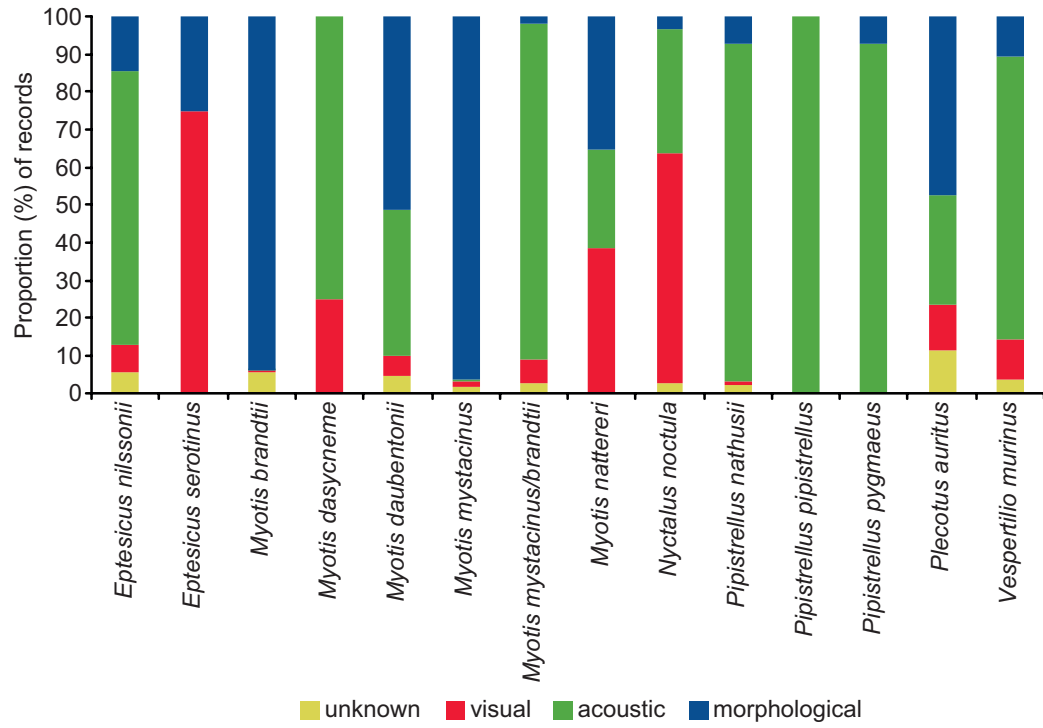

Fig. 3. Proportions of observation types in this study.
Eptesicus nilssonii [Eng: northern bat, Fin: pohjanlepakko, Swe: nordfladdermus (nordisk fladdermus)]

DATA: Observations of the northern bat account for almost half of our data (5107 records, of which $87 \%$ are considered new). The earliest dated record is from 1849, although this species was mentioned for the first time in 1795 (Radloff 1795). Several observations made in close proximity were pooled, hence the number of records for this species differs from the number of observations. Most of the records (approx. 3900) are observations made using a bat detector, as the echolocation calls of the northern bat are loud and easy to register at a distance of 60 to 80 metres (Skiba 2003). Even though more data originated from southern Finland than from other parts of the country due to higher observation efforts in the southern and central parts of the country, the data can be considered representative.

Distribution: The northern bat is a Palearctic species with a wide distribution, reaching from Europe to eastern Russia and Mongolia, with a disconnected region in easternmost Russia and Japan (Coroiu 2016a).

The northern bat is the only bat species occurring in all biogeographical provinces of Finland (Table 4), including Alandia (the Åland Islands) (Fig. 5). Approximately 33\% of the records were from the biogeographical province of Nylandia alone, and $80 \%$ from the five southernmost provinces. Although there are no records from some areas in southern and central parts of the country, if suitable habitats are available the species can probably occur also in those areas. In Lapland, the distribution may be patchy, reflecting harsh conditions and limited availability of roosting sites.

From the northern regions, especially Lapland, only some dozens of records exist; while often anecdotal and lacking species identification, they likely concern the northern bat. Thorough examination of the original sources of these northern records, especially localities, made it possible to avoid several doubles and misinterpretations. In earlier publications based on a very small number of records (e.g. Siivonen 1967, 1968), the species' distribution is shown as continuous throughout Lapland. In this study, only confirmed records and records which most probably concern this species were included, and those indicate the distribution in the north to be scattered.

After comparing our data on this species' distribution in other areas with those of Malmberg (1872) and Mela (1882), or with more recent maps presented by Siivonen (1967, 1968), we can conclude that the distribution of the northern bat did not change much. Newer observations, however, have refined the traditional view of this species as inhabiting the whole country. 
Fig. 4. Biogeographical provinces of Finland (Heikinheimo \& Raatikainen 1971, 1981, Ulvinen 1980).
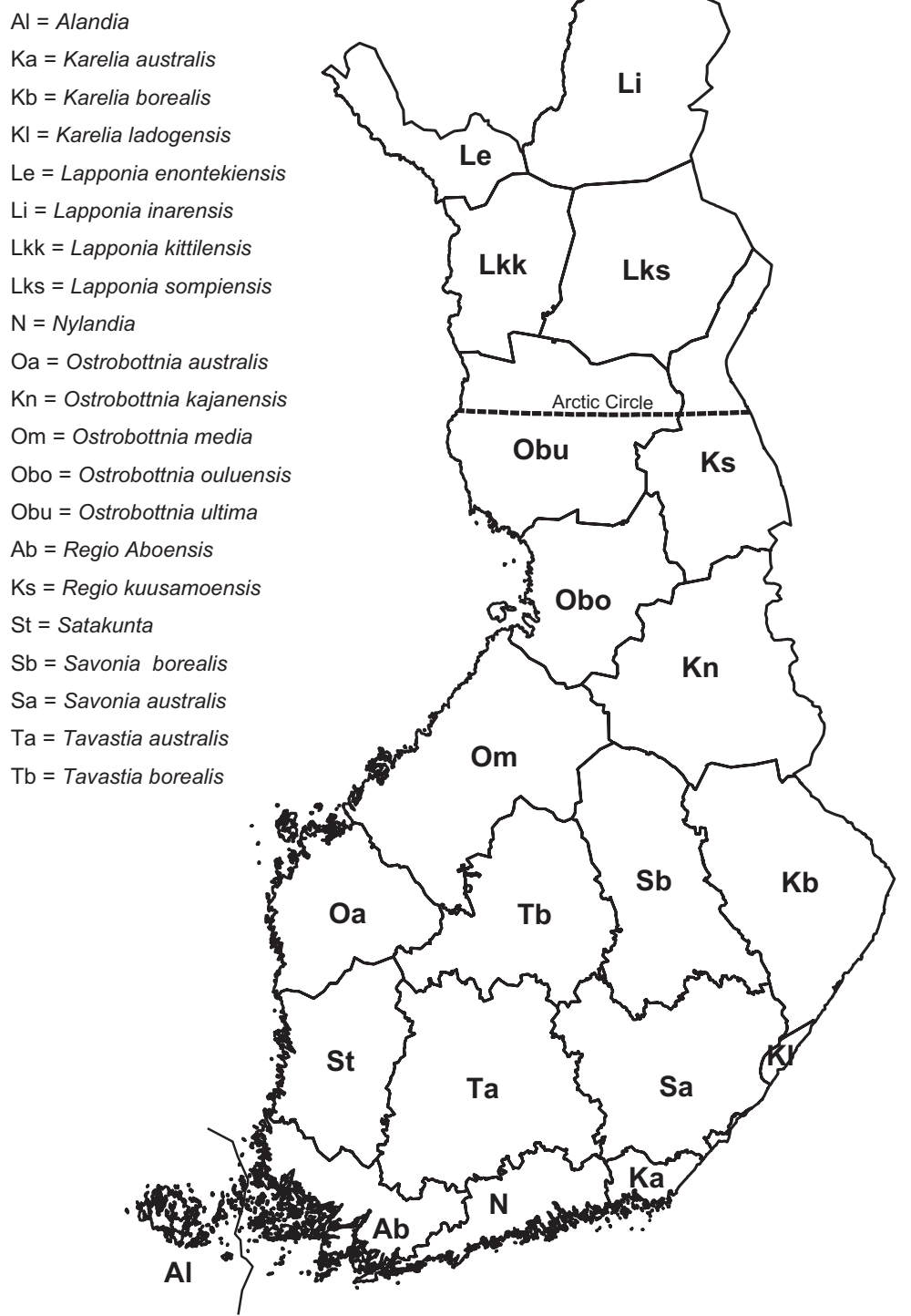

Abundance and status in Finland: The northern bat is the most common bat species in Finland, as evidenced by bat surveys conducted in southern and central Finland. These surveys typically covered areas with mosaics of urban and non-urban habitats, suitable for the northern bat. The northern bat breeds in Finland, and maternity colonies are found in southern and central Finland. The few records from Lapland, the northernmost part of the country, are mainly observations of a flying bat. There are no con- firmed reports of breeding of this species from Lapland, although it is included in the breeding fauna of Lapponia Inarensis compiled by IsoIivari (1975) who in turn cites Siivonen (1972). Siivonen (1972), however, does not mention the species breeding in Lapponia Inarensis.

The northern bat is considered mostly sedentary, with probably limited dispersal behaviour (Hutterer et al. 2005). It is annually observed in many hibernacula in Finland; however, recent data also indicate partial migratory behaviour (see 


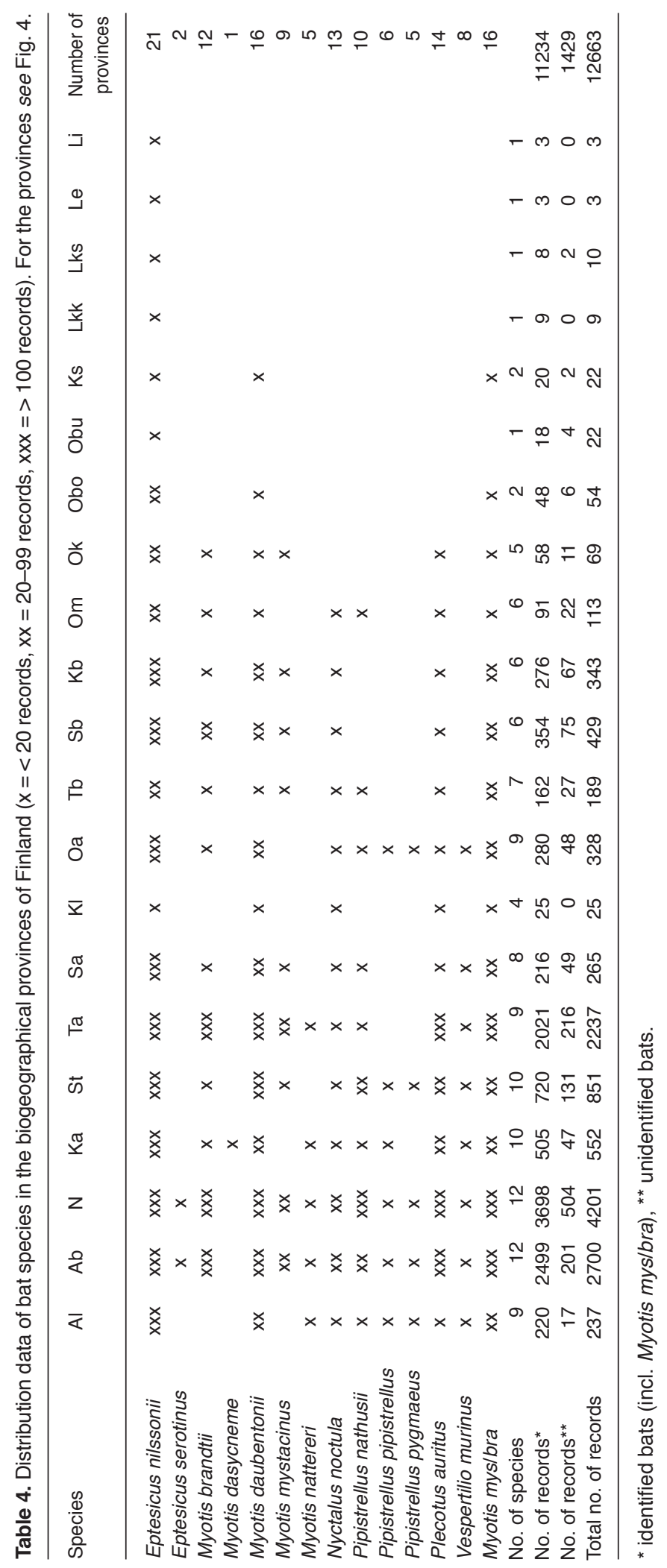


Fig. 5. Distribution of the northern bat in Finland.

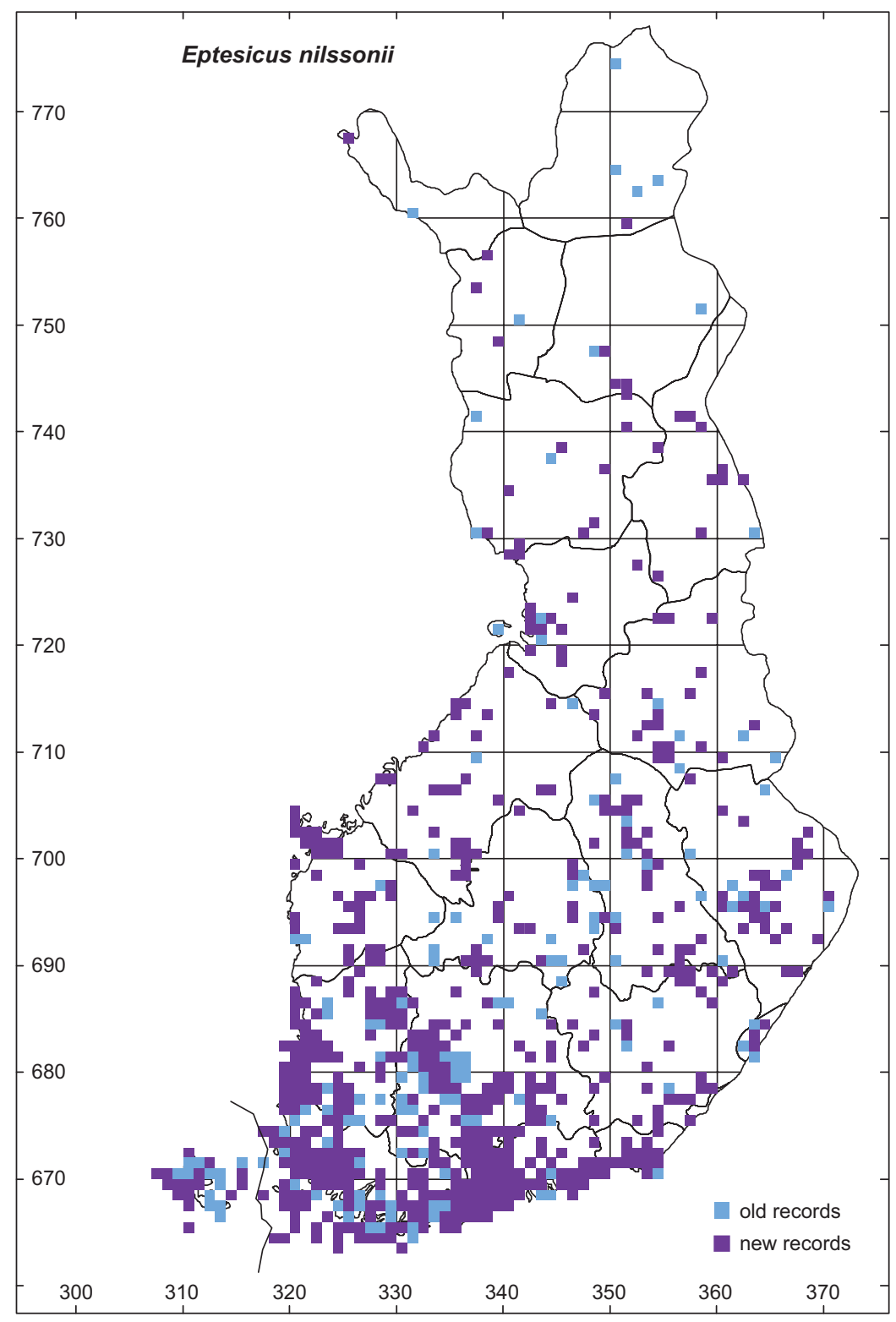

Kyheröinen et al. 2009). This species is a strong flyer, covering distances greater than $10 \mathrm{~km}$ between the roost and foraging areas, especially in late summer (de Jong 1994, Kosonen 2008) or during exploration flights (Haupt et al. 2006).

The northern bat is a generalist species, foraging in a wide variety of habitats including forests with paths and other open- to semi-open structures, rural landscapes with mosaics of fields or crops and settlements, waterbodies, and urban areas such as towns and suburbs (Rydell 1989, de Jong 1994, Kosonen 2008, Wermundsen \& Siivonen 2008). In Finland, reports of roosts are scarce, but the northern bat is known to use buildings as roosts (see Kosonen 2008). Based on observation data in the archives of the Finnish Museum of Natural History, known hibernacula in Finland are mostly man-made structures, such as cellars and bunkers. Hibernation sites in Norway are rock scree deposits (Michaelsen et al. 2013), and such deposits are considered potential hibernation sites also in Finland. Some observations 
indicate that bats could also hibernate in snake hibernacula (Viitanen 1967) and tors (stone fields, N. Fritzén pers. comm.) as well as in deep crevices in rock cliffs. Numbers of bats per hibernacula are typically low, one to a few individuals (authors' own data, Wermundsen \& Siivonen 2010). Hibernation sites of northern bats' have a lower temperature range than those of other bat species, and the species usually hibernates alone not in clusters (Siivonen \& Wermundsen 2008a, Wermundsen \& Siivonen 2010).

Eptesicus serotinus [Eng: serotine, Fin: etelänlepakko, Swe: sydfladdermus]

DATA: The first observation of the serotine in Finland was made in 2008 (Lappalainen 2008). Altogether, only four records of the species were included in this study: one record of a hibernating specimen (Lappalainen 2008) and the other three of daytime flying individuals, of which good photographs were taken (J. Heinonen pers. comm., J. Lehto pers. comm., see also Kosonen 2012).

Distribution: The serotine is an abundant species with a wide Palearctic range, covering most of Europe and parts of Asia (Hutson et al. 2008b). In Finland, a hibernating individual was found in Hanko (Lappalainen 2008) but this bat was later found dead. The records of flying individuals were from Porvoo (J. Lehto pers. comm.), Masku (J. Heinonen pers. comm.) and Parainen (Kosonen 2012). Observations of the serotine were made in only two biogeographical provinces (Table 4) in the southern part of the country (Fig. 6).

Abundance AND STATUS IN FinLand: As records of the serotine from Finland are few, the status of the species cannot be determined. The serotine is mostly sedentary, but Havekost (1960) recorded movements of up to $330 \mathrm{~km}$. With increased passive monitoring of bats, we can expect new observations of the serotine, especially in southern Finland.

Myotis brandtii [Eng: Brandt's bat, Fin: isoviiksisiippa, Swe: taigafladdermus (Brandts mustaschfladdermus)

DAtA: There are 645 records of Brandt's bat, of which $78 \%$ are new. The species Myotis mystacinus sensu lato was split in 1970 into $M$. mystacinus and M. brandtii (Baagøe 1973). In the early 1980s, Rudolph Lehmann re-examined the specimens in the Finnish Museum of Natural History until 1983 and also the specimens in the zoological museums of Oulu, Kuopio and Turku (Lehmann 1983-1984). Bat surveys conducted with a detector commonly treat Brandt's bat and the whiskered bat as a species pair. These data, however, had to be omitted from the analysis at the species level, as echolocation calls alone are usually not enough to distinguish the species (but see Barataud 2015).

Distribution: Brandt's bat is a Palearctic species with a disjunct distribution. It is mainly found in Europe (including central but not the westernmost parts of continent) in boreal regions from Great Britain to Russia as well as in central Asia (Dietz \& Kiefer 2016). Unconnected areas of occurrence appear in China, Mongolia and Japan (Hutson et al. 2008e). Brandt's bat has been recorded in 12 provinces in southern and central Finland (Table 4) but the records are scattered (Fig. 7). There are only few records from western coastal areas, and between the western and central parts of the country are large areas where this species was never observed. An area where the species has been frequently recorded covers southwestern Finland. The northernmost records in Finland are from the same latitudes as in Sweden, approx. $64^{\circ} \mathrm{N}$ (Ahlén 2011). Despite the growing number of bat surveys and research projects, the distribution maps of the whiskered or Brandt's bat have changed only little. The maps of Brandt's bat records in Lehmann (1983-1984) and Skarén (1992) are quite similar to the one presented here, even though more records were available in this study. Further study is needed to clarify whether the records from southeast Lapland are those of Myotis mystacinus or M. brandtii (see below).

AbUNDANCE AND STATUS IN Finland: Brandt's bat is common, locally even outnumbering the northern bat, commonly in areas dominated by forests. However, the distribution of Brandt's bat remains very patchy, because normally detector observations cannot be used to identify Brandt's or the whiskered bat. Records are common in the east, and very few near the western coast, possibly due to barrenness of the inner parts of 
Fig. 6. Distribution of the serotine in Finland.

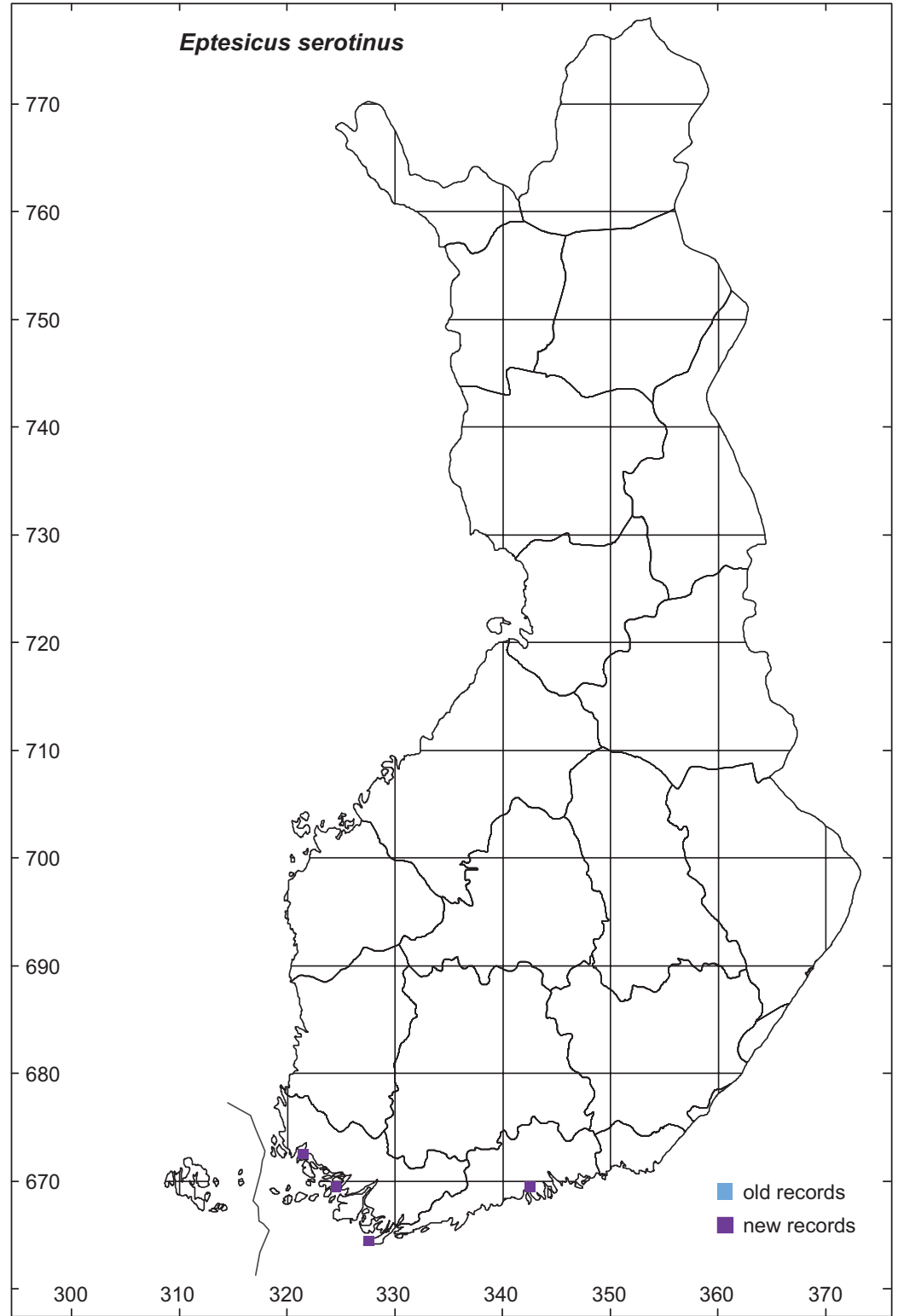

Ostrobothnia or scarcity of surveys during which individuals are caught.

This species is often found foraging in forests. Some longer flights of Brandt's bat were recorded (see Hutterer et al. 2005) but no indication of migration were found. In a radio-tracking study, Vihervaara et al. (2008) recorded Brandt's bats flying on average 950 metres from their roosts to foraging areas. The species hibernates in Finland.

Brandt's bat is a breeding species in Finland. Maternity roosts are typically located in old buildings (e.g. Lehmann 1983a, Hagner 1987, Jäppinen 1987, Vihervaara et al. 2008). Nyholm (1965) found most of the roosts of whiskered bats in buildings. At the time of his research, however, the species was Myotis mystacinus sensu lato, as Myotis mystacinus had not yet been separated from M. brandtii. Thus, his data may also refer to Brandt's bat. In 1990, Haukkovaara (1997) found colonies of the whiskered bat, Brandt's bat and the northern bat in a big attic; the most numerous was Brandt's bat (140-180 indiv.). 


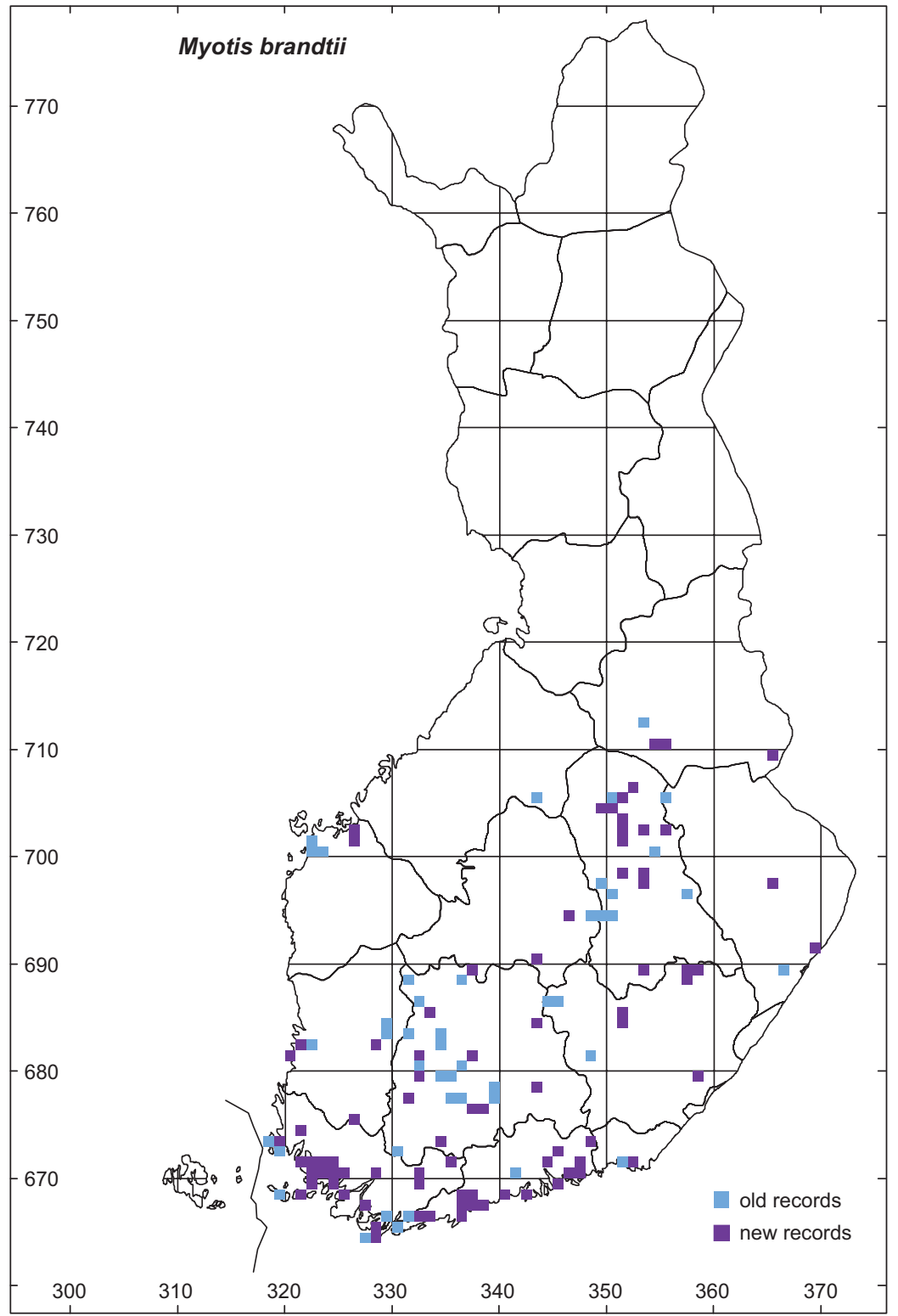

Fig. 7. Distribution of Brandt's bat in Finland.

In hibernacula, Brandt's bat cannot be separated from the whiskered bat without disturbing the hibernating bats. The species pair Myotis mystacinus/brandtii is often found hibernating in moist underground sites, such as natural and man-made caves (Wermundsen \& Siivonen 2010). However, other studies report hibernation occurring in maternity roosts, that is, in buildings (Jäppinen 1987).
Myotis dasycneme [Eng: Pond bat, Fin: lampisiippa, Swe: dammfladdermus

DATA: The first pond bat observed in Finland was a hibernating individual found in south-eastern Finland in 2002 (Siivonen \& Wermundsen 2003b). Only three further published records exist, all made with a bat detector (Fig. 3) (Siivonen \& Wermundsen 2006, Lindstedt \& Laine 2013).

Distribution: The pond bat occurs in central and eastern Europe, from northwestern 
France to central Russia (Piraccini 2016), but not in the southern parts of the continent. In Finland, all records are from a single $10-\mathrm{km}^{2}$ square (Table 4) in the Karelia Australis biogeographical province in the southeastern corner of the country, (Fig. 8). The exact location of one record is unknown. New observations, not included in the map, revealed occurrence of the pond bat also along the Vuoksi river (Savonia Australis), approx. $120 \mathrm{~km}$ north-east of the mentioned square (K. Kuitunen pers. comm.). Records of the species from western Russia near Finland are scarce and mostly from the area south of St. Petersburg (Chistyakov 2002). Large numbers of pond bats were found hibernating near St. Petersburg (I. Popov pers. comm.).

Abundance and status in Finland: The status of the species in Finland is thus far unclear due to the absence of information on breeding and existence of just one winter record. In central and northern Europe, the pond bat is a facultative migrant (Hutterer et al. 2005). The longest recorded flights in Europe were 344 and $330 \mathrm{~km}$ between the Netherlands and Belgium (Fairon 1967, Sluiter et al. 1971). Long flights were also observed in Russia (summarised in Hutterer et al. 2005). The pond bat is considered migratory in Sweden (Ahlén 2011) but sedentary in Estonia (Masing 2015). The Finnish summer observations were of individuals flying above rivers (Siivonen \& Wermundsen 2006, Lindstedt \& Laine 2013, K. Kuitunen pers. comm.).

\section{Myotis daubentonii [Eng: Daubenton's bat, Fin: vesisiippa, Swe: vattenfladdermus]}

DAtA: Daubenton's bat is the second most common bat species in Finland, accounting for $20 \%$ of the data used in this study. Records of the species number in total 2556 , some of which are clusters of several records located in close proximity. Of all the records, $89 \%$ are classified as new. Extensive data exists on captured individuals, because most of the ringed bats in Finland belong to this species. Additionally, many observations were made using a bat detector. Daubenton's bat is quite easy to find in two ways: first, by observing lake shores and river banks, where its characteristic flight behaviour near the water sur- face is easy to see. Second, by using a bat detector, as its echolocation calls can be heard from 15 metres (Barataud 2015) or even from a distance of 40 to 50 metres (Skiba 2003). More data is available from southern Finland than other parts of the country. Some of the unidentified bat observations from northern Finland could concern Daubenton's bat but this is unlikely because observers would probably have identified this species had they seen a bat flying above a water surface.

Distribution: Daubenton's bat is a Palearctic species with its distribution reaching from Portugal in western Europe to the Korean Peninsula and Japan in Asia (Stubbe et al. 2008). In Finland, Daubenton's bat is widespread and common. It was recorded mainly in southern and central parts of the country, in 16 out of 21 biogeographical provinces (Table 4 and Fig. 9) which may be related to higher observations efforts in those areas. Some observations, however, were made further north, and recently even above the Arctic Circle (Siivonen \& Wermundsen 2008b). Despite numerous new records, there are still large areas with no reported observations. This may be related to low observation efforts and/or barren landscapes in Ostrobothnia, especially in the western inland areas.

Our data include confirmed first observations from five biogeographical provinces, including two provinces further north (see Haukkovaara 1993, Stjernberg et al. 1993, Mitchell-Jones et al. 1999). In fact, of the common bat species in Finland, the distribution of Daubenton's bat has changed the most. The northernmost records are fairly new and result from a targeted survey by Siivonen and Wermundsen (2008b) to Lapland and other northern provinces. Their survey aimed to find the species in locations lacking previous records, mainly river valleys between $64^{\circ} \mathrm{N}$ and $66^{\circ}$ N. Siivonen and Wermundsen (2008b) obtained several new records, without which the distribution area in Finland would have reached almost the same latitude as in Sweden.

Abundance and status in Finland: Daubenton's bat is a common and abundant breeding species, found in many areas in Finland. Despite observations of many individuals foraging near waterbodies, known nursery roosts are few. The colonies that were found, were not very large either, typically consisting of some dozens of 


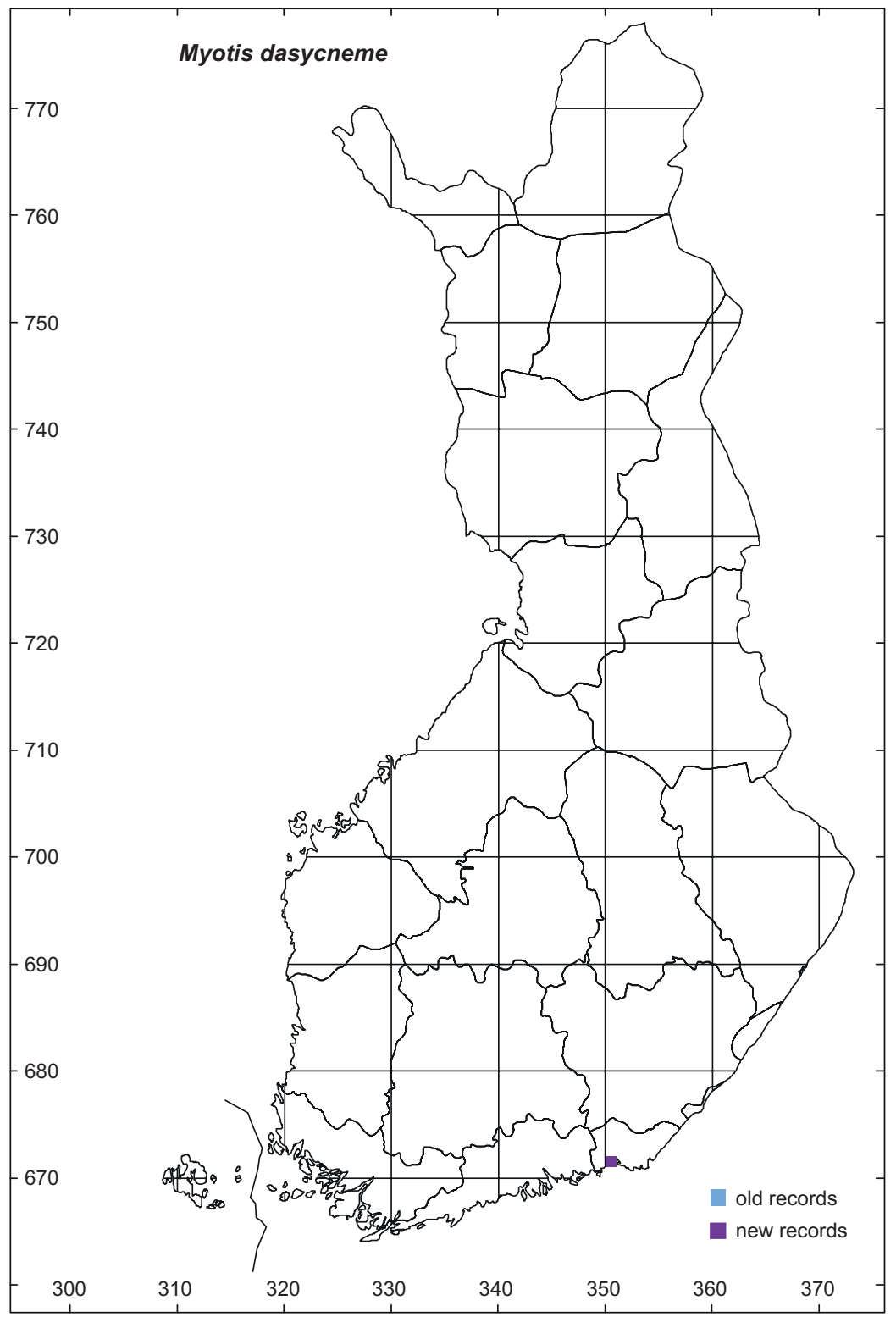

Fig. 8. Distribution of the pond bat in Finland.

individuals. Daubenton's bats hibernate in Finland and are found in several hibernacula. However, these records concentrate in southern and coastal areas; very little is known about the hibernation sites or numbers of hibernating bats in other areas. This species is sedentary, although some longer flights were recorded in Europe (up to $304 \mathrm{~km}$; summarised in Hutterer et al. 2005). No long-distance flights were observed in Finland, however, and the ringing data is rather small (Finnish Museum of Natural History).
Daubenton's bat typically forages near and above waterbodies such as ponds, lakes and rivers. This bat also hunts in forests and is occasionally found also in other places, such as edge habitats, parks and harbours (Wermundsen \& Siivonen 2008). Maternity roosts and other summer roosts are often in woodpecker holes (Nyholm 1965, Lehmann 1983a), bridges, bird boxes (third author's unpubl. data) and bat boxes (e.g. Sallamaa et al. 2011) and occasionally also in buildings (e.g. Lehmann 1983a). The species 
Fig. 9. Distribution of Daubenton's bat in Finland.

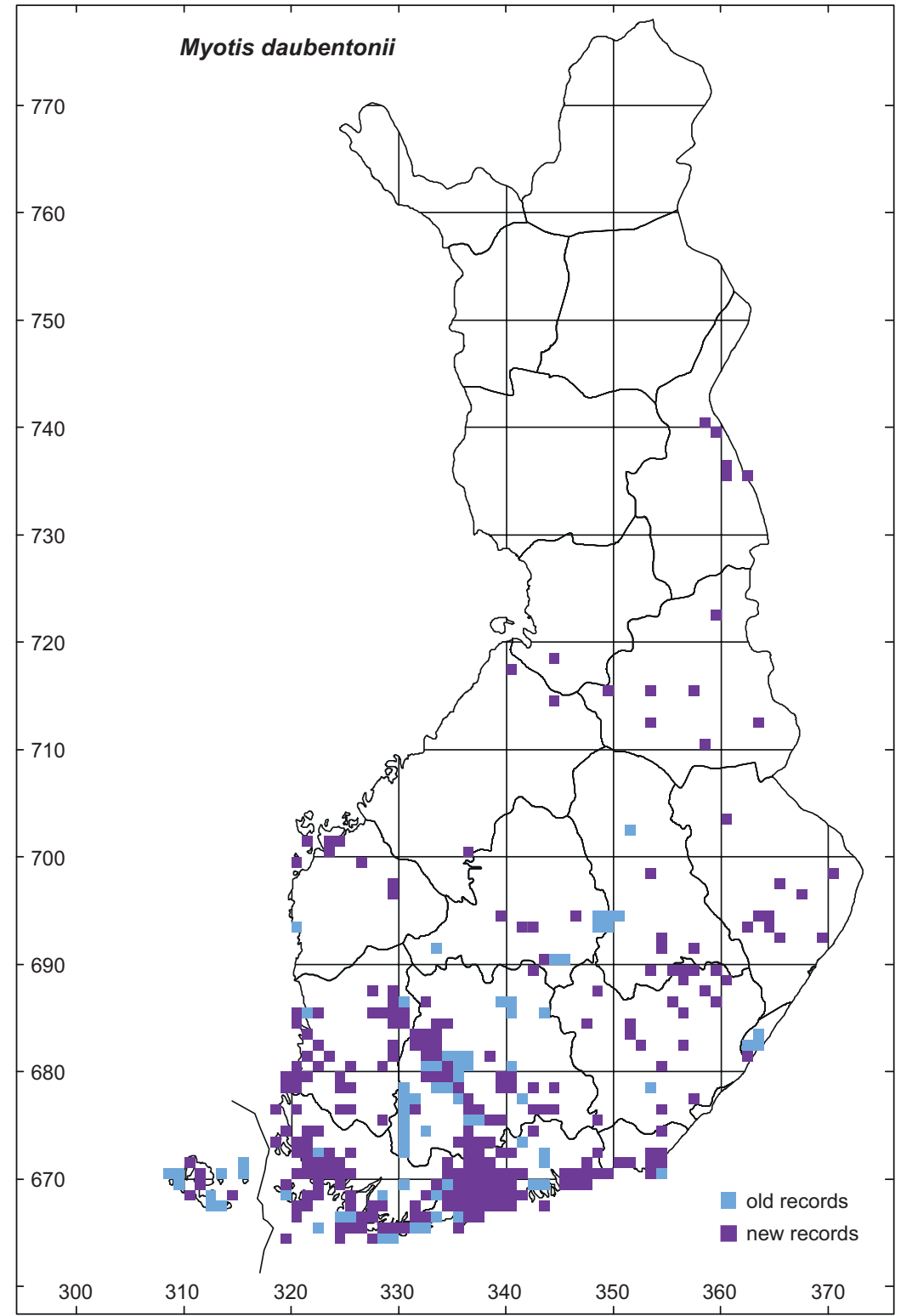

hibernates in moist conditions (Wermundsen \& Siivonen 2010), mainly in man-made underground structures, such as caves and bunkers.

Myotis mystacinus [Eng: whiskered bat, Fin: viiksisiippa, Swe: mustaschfladdermus

DATA: Only 189 records of this species exist, of which 78\% are new. The species Myotis mystacinus sensu lato was divided into M. mystacinus and M. brandtii in 1970 (Baagøe 1973). The whiskered bat (Myotis mystacinus) can only be separated from Brandt's bat (Myotis brandtii) morphologically or genetically, and not or with great difficulty, with acoustic methods of detection (see Brandt's bat). Hence, records we used concern mainly ringed animals and museum specimens. In bat surveys conducted with an acoustic detector, the whiskered bat and Brandt's bat are commonly observed, typically being treated as a species pair. However, omission of 


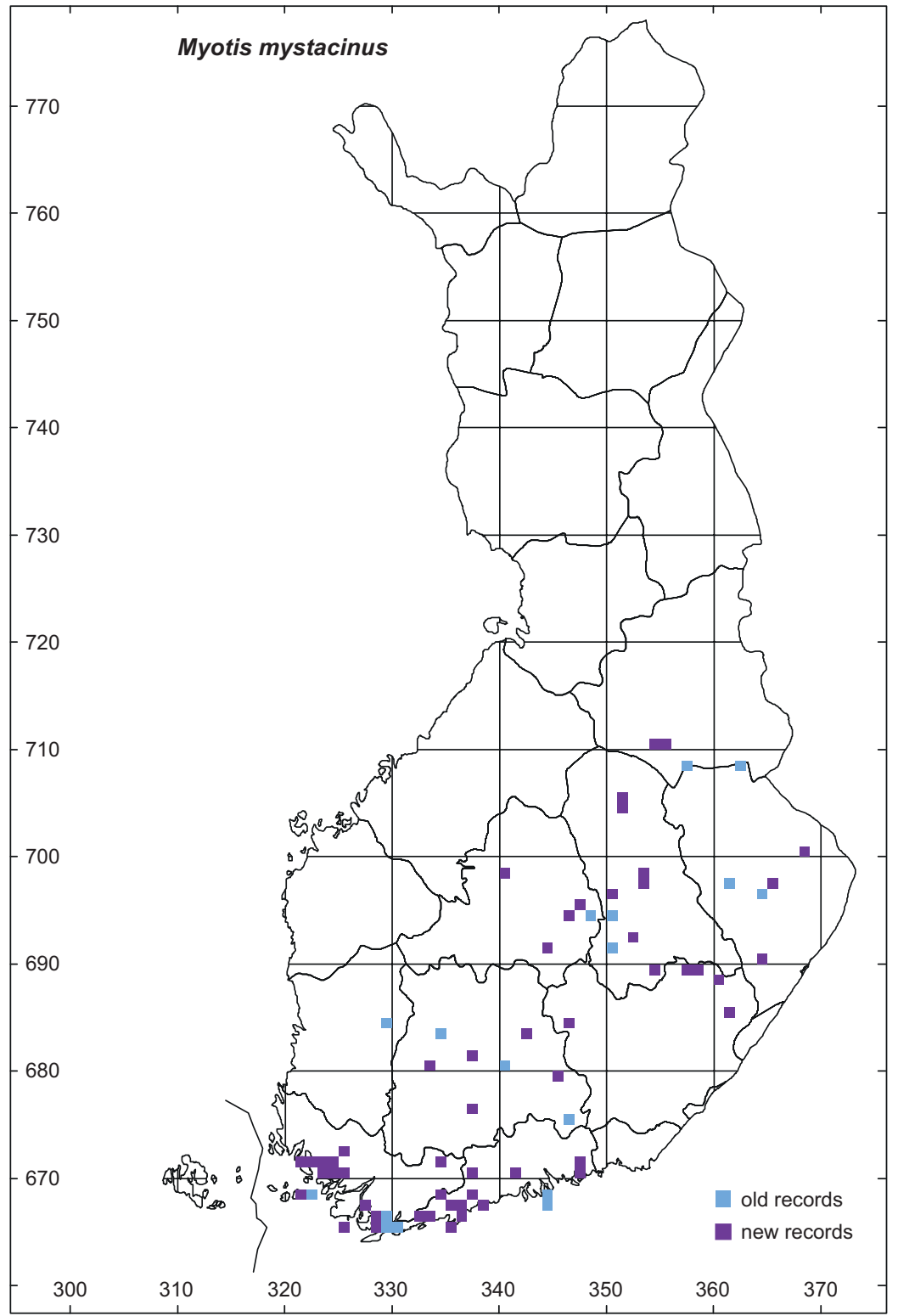

Fig. 10. Distribution of the whiskered bat in Finland.

survey data from the analysis at the species level was necessary, as the species usually cannot be separated by echolocation calls (however cf. Barataud (2015) for acoustic separation of the species).

Distribution: The whiskered bat is a Western Palearctic species with a wide distribution in Europe, from Morocco to Scandinavia (Dietz \& Kiefer 2016). Its distribution covers nine provinces in southern and central Finland (Table 4 and Fig. 10). The records are mostly scattered, however, with no discernible large uniform areas of neighbouring grids. There are no records of the species from western coastal areas, except from the southwestern region, the location of recent active bat research. Despite the growing number of bat surveys and research projects, no major changes have occurred in the distribution patterns of either the whiskered bat or Brandt's bat. However, the data on distribution of Myotis mystacinus/brandtii (see Fig. 11) indicate that either one or both species occur in a wider 
Fig. 11. Distribution of Myotis mystacinus/brandtii in Finland.

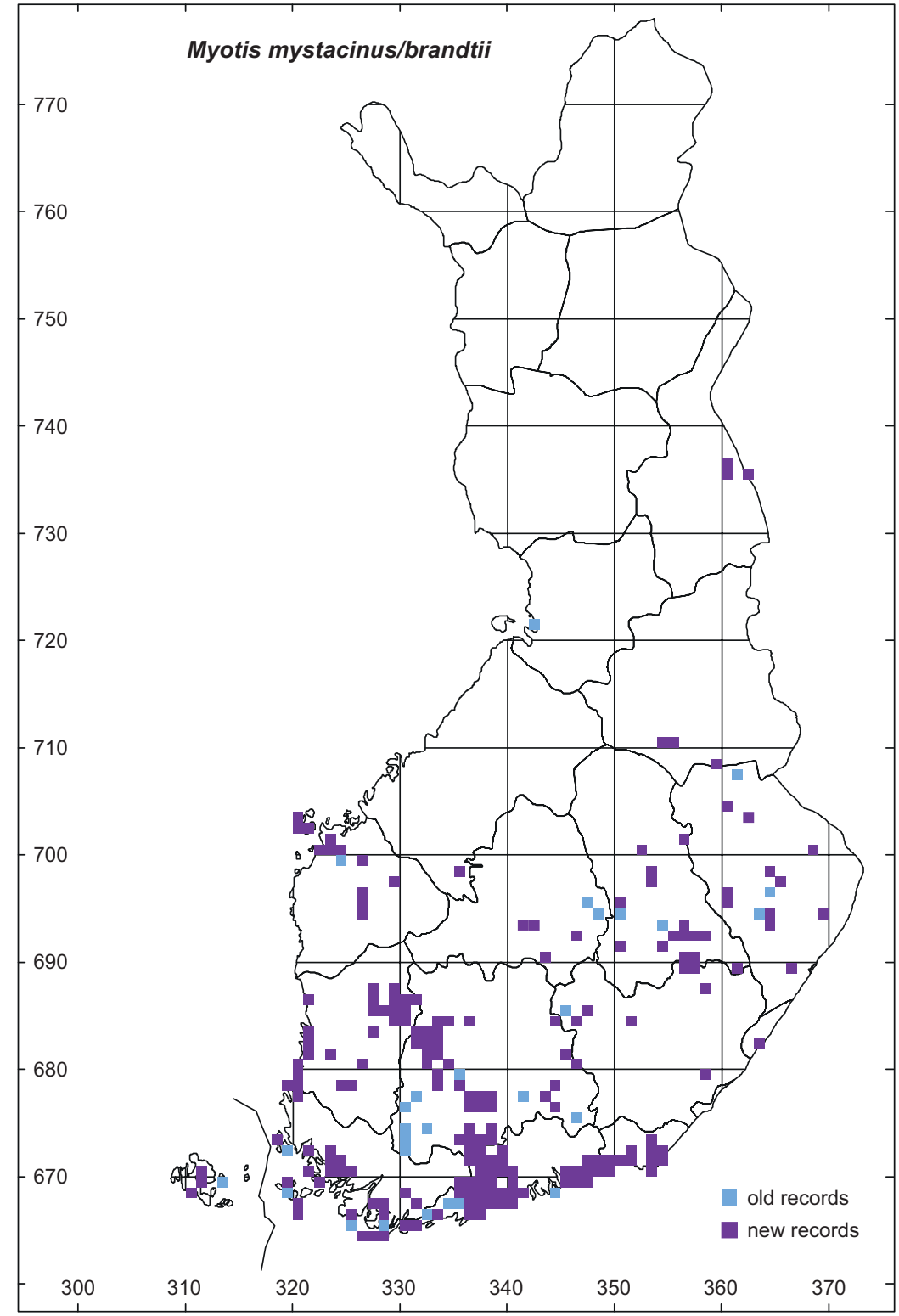

Abundance AND status in Finland: The whiskered bat is poorly known in Finland. The study by Nyholm (1965) focusing on the whiskered bat mainly concerned Myotis mystacinus sensu lato, that is, either the whiskered bat or Brandt's bat. In Finnish ringing data and museum collections the former is less abundant than the latter. The distributions of both species appear patchy, presumably due to the limited data. Records of the whiskered bat are more abundant in eastern than western Finland. 
Whether this pattern reflects the real situation or is the result of non-systematic sampling is unknown. The inner parts of Ostrobothnia in western Finland are partly flat and barren, with large oligotrophic bogs and open fields, which may limit the distribution of most bat species due to the lack of insects and the disinclination of some bat species to cross large fields.

The whiskered bat breeds in Finland. Very few records of roosts are available, but the known maternity roosts are usually located in buildings, and the species can form mixed colonies with other species. Haukkovaara (1997) found colonies of the whiskered bat, Brandt's bat and the northern bat in a big attic, with the number of whiskered bats being fairly low (1020), however. The whiskered bat is sedentary and typically does not make long-distance flights (Hutterer et al. 2005), and hibernates in Finland.

This species prefers forests. According to Ahlén (2011), in Sweden it also favours parks, pastures and grove meadows. Although records are few, the whiskered bat's roosts were found in buildings (e.g. Lehmann 1983a, Haukkovaara 1997, Vihervaara et al. 2008). Although according to Nyholm (1965) most of the roosts of whiskered bats were in buildings, it is uncertain to which species those reports refer to as at the time Myotis mystacinus sensu lato was not yet separated into two species (the whiskered bat's and Brandt's bat). It seems that the whiskered bat hibernates in relatively warm and moist underground locations (Wermundsen \& Siivonen 2010), but as previously stated this information may also concern Brandt's bat.

\section{Myotis mystacinus or Myotis brandtii} [Eng: whiskered bat or Brandt's bat]

In the records from the studies using an acoustic detector and other surveys the species pair $M$. mystacinus/brandtii is common. Data on this species pair number 1517, of which some are closely located clusters of original records. The distribution map of the whiskered bat/Brandt's bat is less patchy than the map of either of the two species (Fig. 11). In good conditions, this species pair can be separated from other Myotis species by echolocation calls but not from each other (however see Barataud (2015). The northernmost records at $66^{\circ} \mathrm{N}$ in the Oulanka river valley (Regio Kuusamoensis) are from a targeted survey by Siivonen and Wermundsen (2008b). All other records are from further south. Either one or both species can, however, occur in the area between the new northernmost records and the more central records.

\section{Myotis nattereri [Eng: Natterer's bat, Fin: ripsisiippa, Swe: fransfladdermus]}

DATA: Natterer's bat records number just 31, of which 23 date from 2001 onwards. The three oldest records are museum specimens from between 1849 and 1873 (Stjernberg 1996); the remaining five are from the 20th century. The data comprise observations of hibernating bats, acoustic detector records, ringed animals and few museum specimens (Fig. 3). In addition to the records used in this study, three museum specimens, two adult females and one juvenile, are from Pitkäsaari (approx. 60 $30^{\prime} \mathrm{N}, 2^{\circ} 40^{\prime} \mathrm{E}$ ) in the municipality of Johannes near Viipuri, a city formerly belonging to Finland. These specimens are apparently from a maternity colony, as the adult females gave birth soon after being caught (Kivirikko 1940). Despite the growing number of bat surveys and hibernacula checked, the annual number of records is still very small. The species is difficult to observe with an acoustic detector, as its echolocation calls are very weak and can be heard from no farther than 15 m (Barataud 2015).

DisTRIBUTION: Natterer's bat occurs in Europe and northwestern Africa; separate areas occur in southwestern Russia, Georgia and Iran (Hutson et al. 2008a). In southern Finland, Natterer's bat was recorded between Virolahti in the southeast (first author's unpubl. data) and the Åland Islands in the west (I. Ahlén pers. comm.) (Fig. 12). The northernmost records are from Hollola (I. Ahlén pers. comm., see also Stjernberg 1996) and Asikkala (museum specimen) at about $61^{\circ} \mathrm{N}$. In the Turku area in southwestern Finland, several observations of the species were made and its hibernacula, sometimes with several individuals, located (E. Kosonen unpubl. data). Existing records are from five biogeographical provinces 


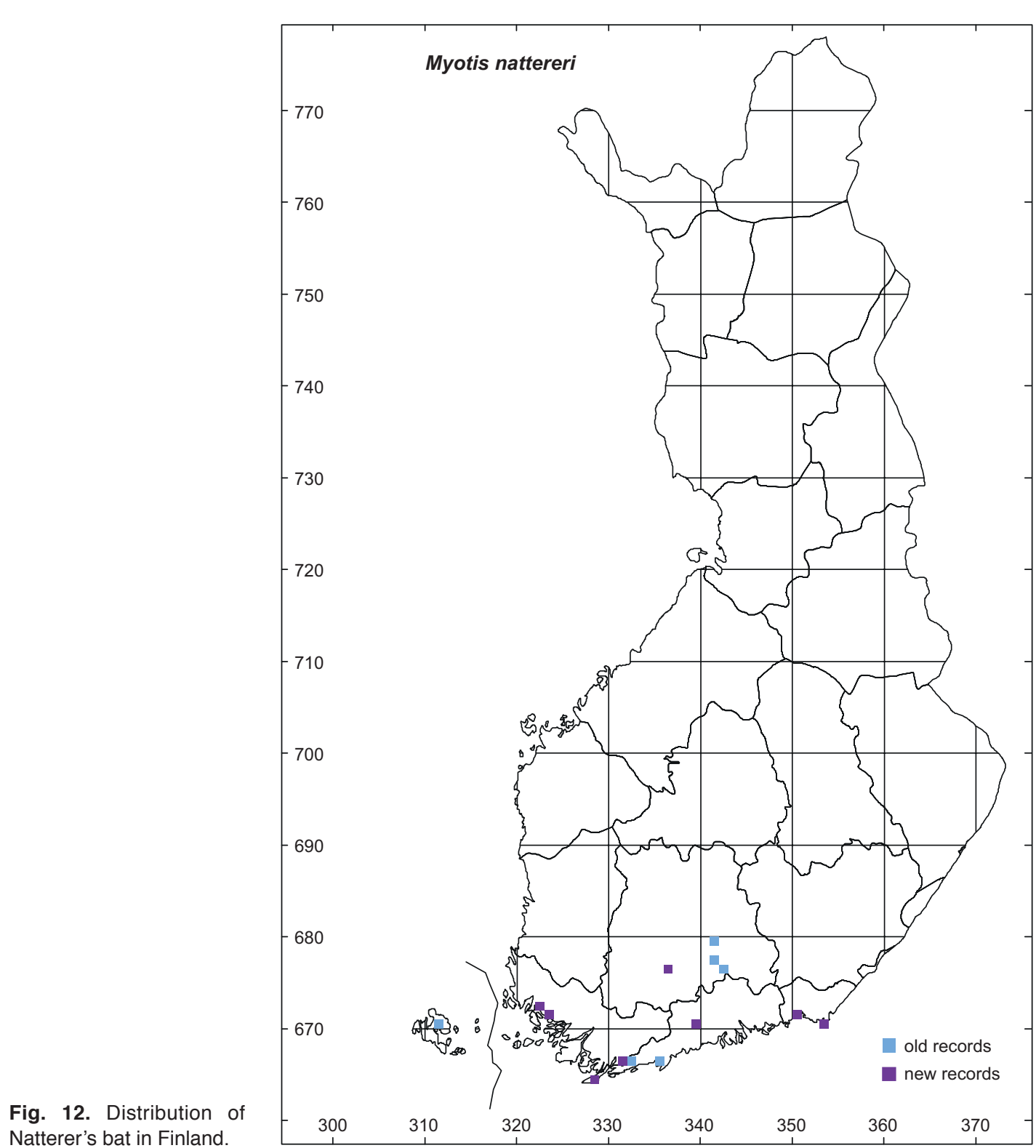

only (Table 4). Old observations come from few sites in three provinces. The species was recorded mostly near the coast, including one record from 1979 from the municipality of Sund, the Åland Islands (see Kyheröinen et al. 2010). Two of the three oldest records (from 1849 and 1853) are museum specimens from Inkoo, southern Finland, and the third one (from 1873) is from Tuusula, southern Finland (uncertain identification, see Stjernberg 1996). Old records are summarised in detail in Stjernberg $(1996,1998)$.
Abundance And status in Finland: No old and/or new reports of maternity colonies of the species exist even though several individuals were caught and ringed in southwest Finland. In the collections of the Finnish Museum of Natural History, however, there is one juvenile specimen from Inkoo from 1853.

Natterer's bat was found hibernating in Turku for several years (E. Kosonen pers. comm.). Siivonen and Wermundsen (2008c) reported 20 hibernating individuals and seven summer 
records. The maximum number of individuals observed in the same hibernaculum was five (Siivonen \& Wermundsen 2008c). The numbers of observations are limited, but being from both summer and winter, the species is considered to breed in Finland. Natterer's bat was classified as endangered in the most recent Red List of Finnish Mammal Species (Liukko et al. 2019). This species is considered sedentary; however, the evidence of migrations exists (summarised in Hutterer et al. 2005) but not from Finland.

Records of foraging Natterer's bats are mainly from woodland edges and parks usually near water (e.g. Stjernberg 1996, Siivonen \& Wermundsen 2008c). In Finland, the species has been found hibernating in cellars and other underground structures, such as man-made caves.

Nyctalus noctula [Eng: noctule, Fin: isolepakko, Swe: större brunfladdermus (stor fladdermus)]

DATA: In Finland, the noctule has been known for long but is relatively rare. The first record presented here is from 1952, although the species was already mentioned in 1881 (Table 1). Approximately 50 records exist from between the 1950s and the 1980s. Since the 1980s, observations have been made in most years; currently there are more new records (100) than the old ones (52). The data comprise almost exclusively observations made with an acoustic detector or sightings of the species, with only three museum specimens available (Fig. 3). For example, reports of noctules flying during daytime come from bird ringing stations, bird migration observatories, and from islands off the south coast of Finland where these bats were observed by bird watchers used to estimating the size of a flying animal. To be included in these data, sighting records had to include size and other identifying characteristics of the animal. However, the risk of misidentification always exists, as the species could have been confused with the serotine or other Nyctalus species.

The species is easy to spot with a bat detector, as its echolocation calls are loud (Barataud 2015). Some people can even hear it, as the frequency is approx. $20 \mathrm{kHz}$, which is near the upper limit of human hearing range.

Distribution: The noctule is common and widespread in Europe. Its Palaearctic range reaches to the Caucasus in the east (Csorba et al. 2016). Finnish records of the species are from 13 out of 21 biogeographical provinces including the southern parts of the country and the west coast (Fig. 13 and Table 4). Several inland observations also exist, including eastern Finland near the Russian border. The northernmost record is from Kalajoki at $64^{\circ} \mathrm{N}$ (Pöyry Management Consulting Oy 2012). As the species is a generalist and a very strong flyer covering long distances, it may occur in a greater area than currently known.

Abundance and status in Finland: Despite observations made annually and at different times of the summer, it is unclear whether the noctule breeds in Finland. However, a pregnant female found on 13 July 1968 (Bergman \& Hackman 1969), and one report from Hamina (southeastern Finland) of one roost in an attic used for several years (Siivonen \& Wermundsen 2006) may indicate that breeding takes place.

The noctule is a long-distance migrant with documented movements of up to $1546 \mathrm{~km}$ (summarised in Hutterer et al. 2005). In Finland, no noctule has yet been ringed, thus the length of migratory flights or the origin of observed specimens is unknown. Indications of noctule migration are based on sightings made at bird ringing stations and observation sites of bats moving from the south over the open sea, as well as from acoustic-detector observations of the species at coastal sites. According to Dechmann et al. (2014), females migrate longer distances than males. Thus, noctules seen in Finland could be females, with males remaining close to their wintering areas. The majority of dated observations are from autumn, between August and October, with smaller numbers made in spring and summer.

\section{Pipistrellus nathusii [Eng: Nathusius' pipistrelle, Fin: pikkulepakko, Swe: trollpipistrell (trollfladdermus)]}

DATA: The first reported record of Nathusius' pipistrelle dates from 1982 (Lehmann 1983b); 
Fig. 13. Distribution of the noctule in Finland.

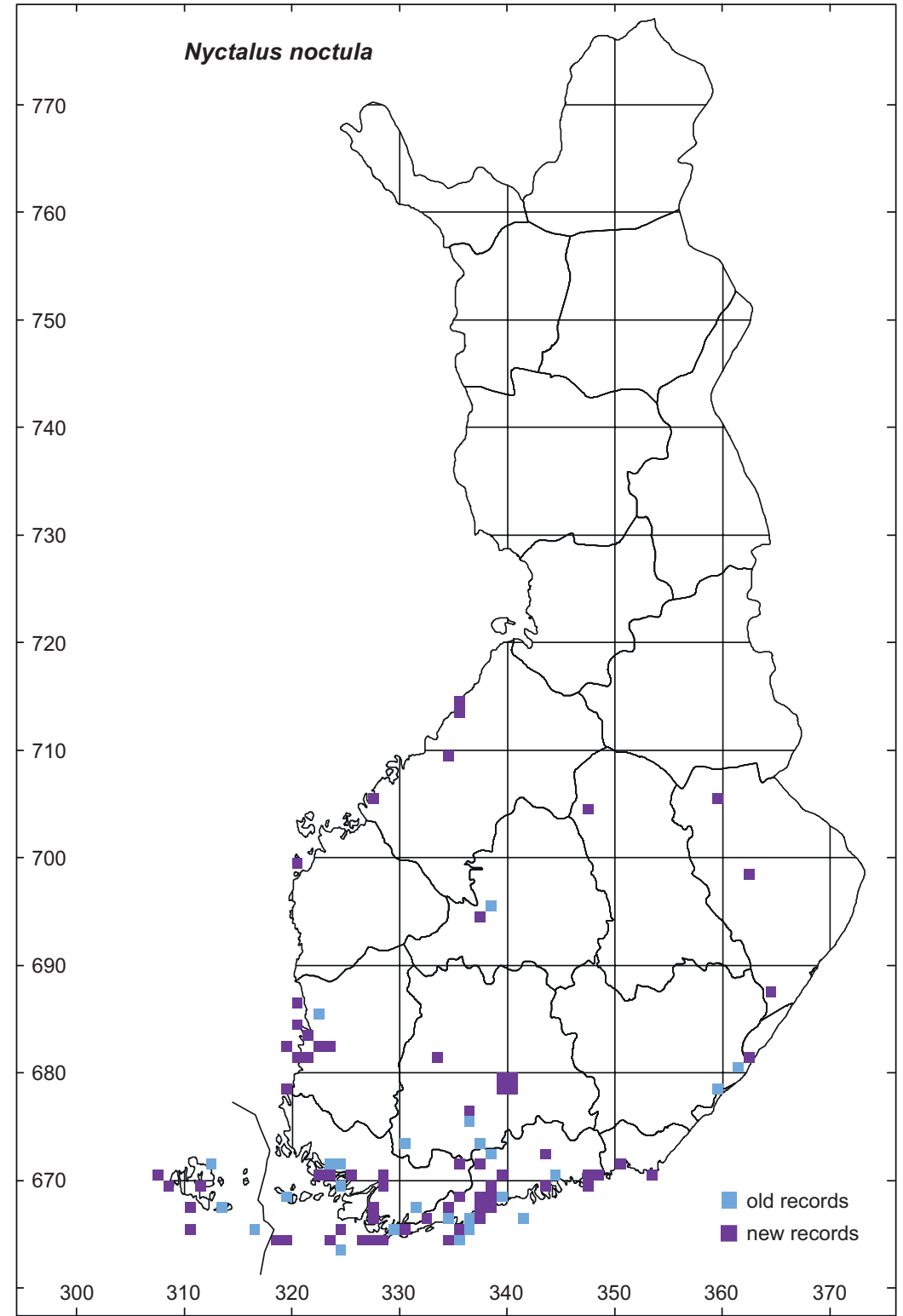

however, an older sound record from the Åland Islands from 1979 was later identified as Nathusius' pipistrelle (I. Ahlén, pers.comm. to the third author on 20 Apr. 2007, Kyheröinen et al. 2009, 2010). The data comprise 232 records, of which all but 5 are new, mostly from the last ten years. Most of the recent data comes from numerous passive monitoring studies conducted for nature surveys in connection with land use planning, especially along the coast with potential habitats for this migratory species. Nathusius' pipistrelle is quite easy to recognise with a bat detector which was used to make the majority of the observations (Fig. 3). Few records are of caught and ringed individuals, and museum specimens account for even fewer.

Distribution: Nathusius' pipistrelle occurs in the Western Palearctic region, from Europe to Asia Minor and Transcaucasia (Paunović \& Juste 2016). Nathusius' pipistrelle was recorded in ten biogeographical provinces in Finland, mainly in the southern, southwestern and west- 


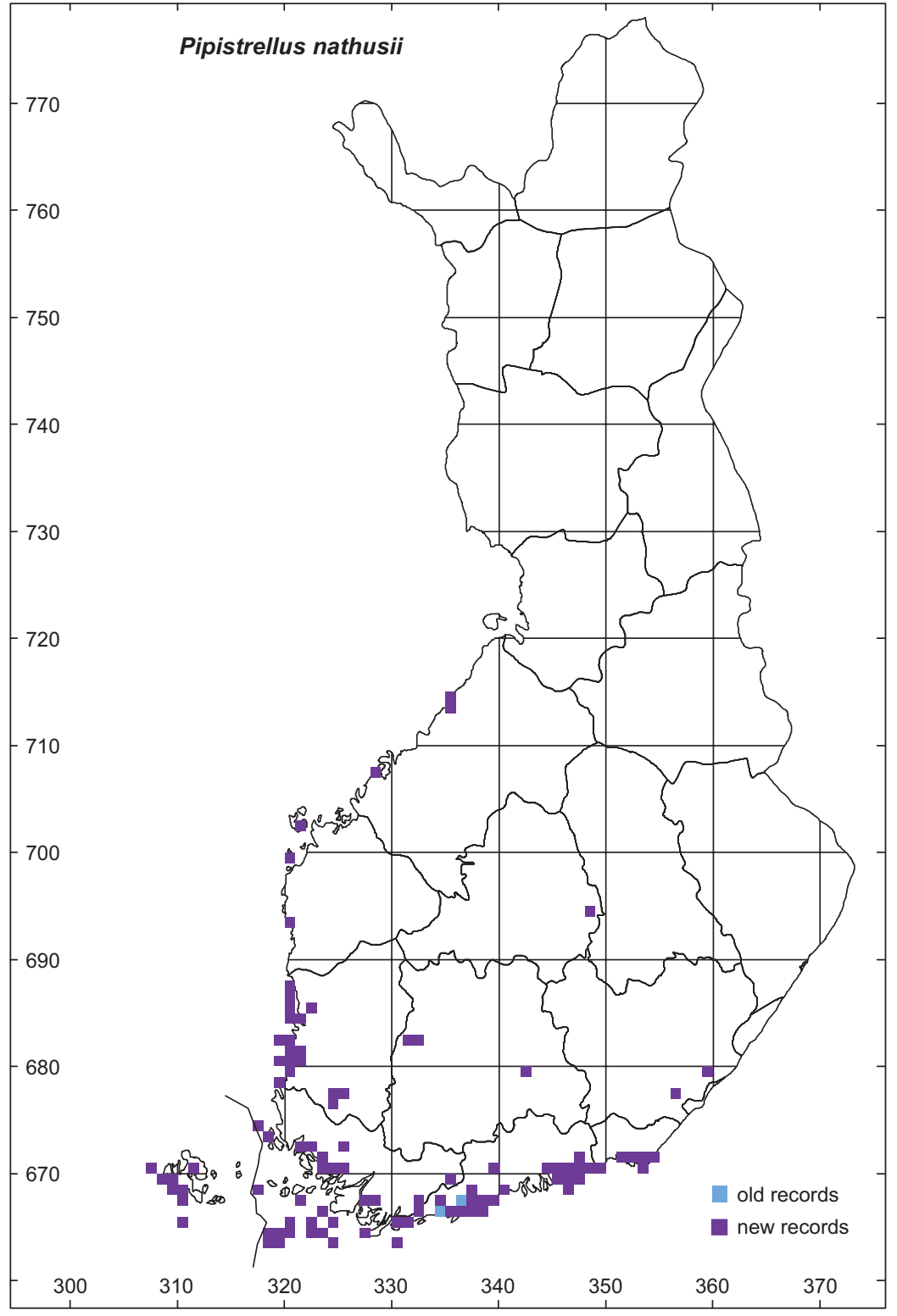

Fig. 14. Distribution of Nathusius' pipistrelle in Finland. ern parts of the country (Fig. 14 and Table 4). Old records are from Nylandia in the south and the Alland Islands. Most records of the species are from coastal areas; however, observations were also made at inland locations. The northernmost records are from Kalajoki (approx. $\left.64^{\circ} 15^{\prime} \mathrm{N}\right)$ and Pietarsaari $\left(63^{\circ} 40^{\prime} \mathrm{N}\right)$ on the western coast. Despite most of the records being from coastal areas, Nathusius' pipistrelle may be more common inland than the current data indicate. Siivonen and Wermundsen surveyed Nathusius' pipistrelle and the common pipistrelle between 2001 and 2003, reporting several new locations for both species, including some on the southern coast for Nathusius' pipistrelle, and one location in central Finland (Rautalampi) (Siivonen \& Wermundsen 2003a, Wermundsen \& Siivonen 2004).

Abundance and status in Finland: Nathusius' pipistrelle currently seems more common and widespread than earlier, probably due to increased survey activity; however, this change 
may also reflect a genuine pattern of range expansion. Lundy et al. (2010) presented a current (from the 1980s to present) and projected range expansion in the United Kingdom based on records of the species and modelling of habitat and climate. The species has not been found hibernating in Finland, in concordance with its migratory patterns in other European countries. Breeding of the species was confirmed in 2006 in southeastern Finland (Hagner-Wahlsten \& Kyheröinen 2008) and in 2009 in Helsinki (Hagner-Wahlsten \& Karlsson 2010). These maternity roosts were in old buildings. Further recent evidence of breeding is based on juveniles captured in Helsinki and Espoo (first author's unpubl. data). In the most recent Red List of Finnish Mammal Species, Nathusius' pipistrelle is classified as vulnerable (Liukko et al. 2019).

Nathusius' pipistrelle is known to migrate long distances between summer and winter grounds. Extensive ringing data from Latvia (Pētersons 2004) indicate journeys of over $1900 \mathrm{~km}$ through Europe (see also Hutterer et al. 2005). The direction of autumn migration is mainly south-west (Hutterer et al. 2005). In Finland, the species is not observed during wintertime; instead, many records are made during migration time, especially in the autumn. Based on the data from several countries around the Baltic Sea; in spring, migration activity of this species was correlated with latitude, but not in autumn (Rydell et al. 2014). Thus the spring migration starts earlier in Germany and other southern localities than in Finland. Nathusius' pipistrelles may migrate not only over the Baltic Sea but also across the narrow strait (Kvarken, at about $63^{\circ} \mathrm{N}$ ) between Finland and Sweden. The data collected in that area shows that Nathusius' pipistrelles occur on the islands during the autumn migration period (August-September) and move in the area from east to west (Fritzén 2014, 2015, 2019).

\section{Pipistrellus pipistrellus [Eng: common} pipistrelle, Fin: vaivaislepakko, Swe: sydpipistrell (pipistrell)

DATA: The common pipistrelle is a fairly new species in Finland, being observed for the first time in 2001 (Salovaara 2001). Since then, 37 records exist. All observations were made with a bat detector; no captured animals or museum specimens exist (Fig. 3). The soprano pipistrelle was separated from the common pipistrelle sensu lato in 1999, first based on their different echolocation calls, and later by genetic analyses (Barrat et al. 1997, Jones \& Barrat 1999). The species is relatively easy to observe with an acoustic detector. However, separating it from Nathusius' pipistrelle or soprano pipistrelle is not always possible, as the echolocation calls of the three species have partly overlapping peak frequencies (Barataud 2015).

Distribution: The common pipistrelle is a common and widespread species. However, due to the relatively recent split of the common pipistrelle sensu lato into soprano pipistrelle and common pipistrelle sensu stricto, its ranges are yet to be defined. The range of the common pipistrelle covers most of Europe, some of northwestern Africa, reaching through south-west Asia to central and eastern Asia (Hutson et al. 2008c).

In Finland, all records of the common pipistrelle are from coastal areas and archipelagos, ranging from southeastern Finland to the west coast (Fig. 15). The northernmost records are from Maalahti (Ostrobottnia, at $63^{\circ} \mathrm{N}$ ). Records of the species are from six biogeographical provinces (Table 4), with the species possibly occurring further north at suitable inland sites.

ABUndANCE AND STATUS IN FInLAND: The common pipistrelle may be more abundant than currently known but still also rare as in the Scandinavian countries (Ahlén 2011, Størkersen et al. 2014). There are no indications of the species breeding in Finland. The common pipistrelle is a migrating species. Buresh (1941) recorded migrations of up to $1150 \mathrm{~km}$, normally they are however much shorter (summarised in Hutterer et al. 2005). Thus, it is likely a migrant in Finland and other northernmost parts of the species' known range. No roost has yet been found.

\section{Pipistrellus pygmaeus [Eng: soprano pipistrelle, Fin: kääpiölepakko, Swe: dvärgpipistrell (dvärgfladdermus)}

DATA: The soprano pipistrelle was observed in Finland for the first time in 2007 (Salovaara 


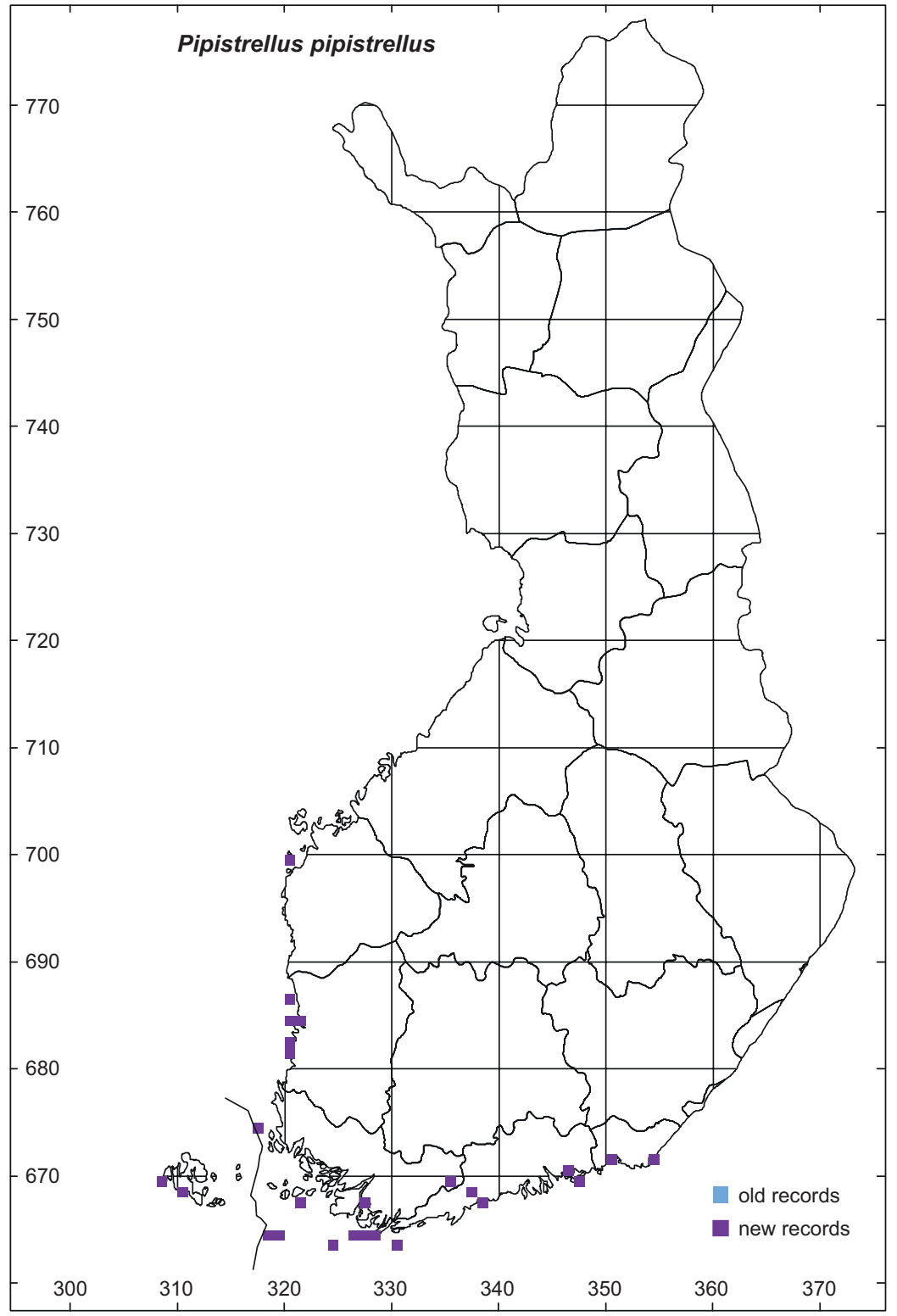

Fig. 15. Distribution of the common pipistrelle in Finland).

2007). The soprano pipistrelle was separated from the common pipistrelle in 1999 (Barrat et al. 1997, Jones \& Barrat 1999). The data comprise 14 records, of which all but one were obtained using a passive monitoring detector (Fig. 3). One dead specimen was found at the Aspskär bird ringing station, an island in the eastern part of the Gulf of Finland.

DistRiBution: The breeding range of the soprano pipistrelle is still unknown due to the fact that this species was separated from the common pipistrelle very recently and records from before it was recognised cannot be used. Its Palearctic range covers the British Isles, much of Europe and western parts of Russia (Benda et al. 2016). All records of the soprano pipistrelle in Finland are from five biogeographical provinces from coastal areas and archipelagos west of Loviisa, a city 90 kilometres east from Helsinki (Fig. 16 and Table 4). The northernmost records are from Maalahti on the west coast, at $63^{\circ} \mathrm{N}$. As the species was first observed in 2007, new 
Fig. 16. Distribution of the soprano pipistrelle in Finland.

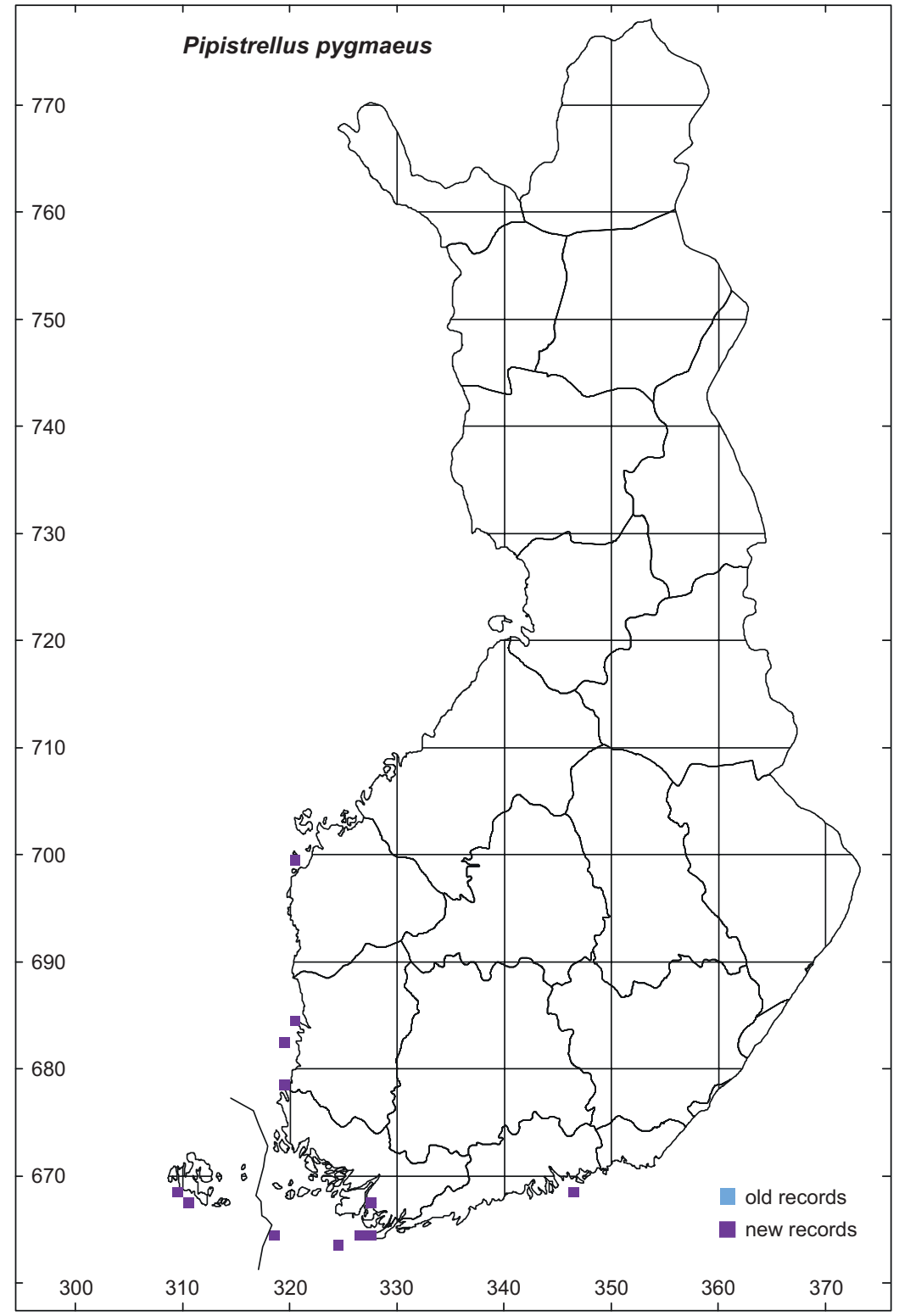

records in the near future may extend its known distribution in Finland.

Abundance and status in Finland: No indications currently exist of the soprano pipistrelle breeding or hibernating in Finland. All records are from coastal sites but the species may also occur inland. As the species was separated from the common pipistrelle fairly recently (see above), ringing data from Europe are scarce, and there are none from Finland. Few of observations (mostly by passive monitoring) were made along potential migration routes in coastal areas. No roosts have been found in Finland.

Plecotus auritus [Eng: brown long-eared bat, Fin: korvayökkö, Swe: brunlångöra (långörad fladdermus)

DATA: The brown long-eared bat is considered a fairly common species in Finland, yet there are only 718 records, of which $82 \%$ are new. Of the 
new records, 53\% comprise caught and ringed animals, originating from quite small areas in southern and southwestern Finland. Many of these records are from areas with bat boxes monitored for several years; the remainder are observations made with an acoustic detector, or bats seen in hibernacula or a summer roost. There are few records obtained from various sources with no description of the observation method. This species mainly uses very quiet echolocation calls, only detectable from approx. $5 \mathrm{~m}$, making it difficult to find with an acoustic detector (Barataud 2015). However, the species is easily identifiable by sight.

Distribution: The brown long-eared bat is an endemic European species with a wide distribution from Portugal to Georgia and Kazakhstan. The range of the brown long-eared bat is from the northern Mediterranean in the south to southern Fennoscandia in the north (Hutson et al. 2008d). In Finland, this species is distributed across the southern and central parts of the country, with records from 14 out of 21 biogeographical provinces (Table 4 and Fig. 17). The northernmost records are from $64^{\circ} 25^{\prime} \mathrm{N}$ (Siivonen \& Wermundsen 2008b), further north than in Sweden where its distribution reaches southern Norrland (ca. $\left.63^{\circ} \mathrm{N}\right)$ where it was observed along the coast (Ahlén 2011). Many of the new sightings are from sites with no earlier confirmed records of the species. On the other hand, many grids contain only old records. Despite many new observations of the species, its distribution area has not expanded much as compared with that presented in older maps (Haukkovaara 1993, Stjernberg et al. 1993), and only two new provinces were included in the new records.

The brown long-eared bat has a sedentary lifestyle and rarely flies long distances (e.g. Kyheröinen 2008), yet it has been found on islands close to the Finnish mainland. A few records from the Åland Islands also exist. Its distribution appears patchy, with areas without records and areas with continuous coverage of grids (Fig. 17). The latter are typically areas where bat observers carried out ringing or surveys. The brown long-eared bat probably occurs in many areas with suitable habitats, but is under-represented in the data as it is difficult to observe with an acoustic detector.
Abundance And status in Finland: The brown long-eared bat breeds in Finland, and is a sedentary species, typically moving only very short distances. In a radio-tracking study in southern Finland, these bats foraged near the roost but sometimes travelled up to $2 \mathrm{~km}$ to foraging areas (Kyheröinen 2008). There is one observation from Finland of a ringed brown long-eared bat found alive $20 \mathrm{~km}$ from the ringing locality in Nylandia, southern Finland (first author's unpubl. data). The brown long-eared bat hibernates in Finland.

Bat and also bird boxes are used for roosting, sometimes even as nursery roosts (Sallamaa et al. 2011). Nursery roosts have also been found in summer cottages in the archipelago off the south coast of Finland (third author's unpubl. data). Hibernating specimens have been found in cellars, bunkers and caves (first author's unpubl. data). Brown long-eared bats typically hibernate alone, that is, not in clusters, and in colder and drier conditions than Myotis species (Wermundsen \& Siivonen 2010).

\section{Vespertilio murinus [Eng: parti-coloured} bat, Fin: kimolepakko, Swe: gråskimlig fladdermus

DATA: The parti-coloured bat is very rare in Finland; the data include 28 records only but the majority of these (25) are new. The first record dates from 1834; the second one from 1981. Three records are from the 20th century, and the rest from the year 2000 onwards. Most of the records were made with a bat detector (Fig. 3), although included are few sightings and two museum specimens.

DistriBuTION: The parti-coloured bat is widely distributed in the Palearctic, from France to China. The westernmost areas of Europe are outside its range, and so are the northernmost ones although the species occurs in Scandinavia (Coroiu 2016c). Records of the parti-coloured bat are mainly from southern Finland, from Virolahti in the south-east to the Alland Islands in the west, with a few records from the western coast (Fig. 18). The northernmost record is from Maalahti, at $63^{\circ} \mathrm{N}$ (Vasko \& Hagner-Wahlsten 2010). New records of the parti-coloured bat are from eight 
Fig. 17. Distribution of the brown long-eared bat in Finland.

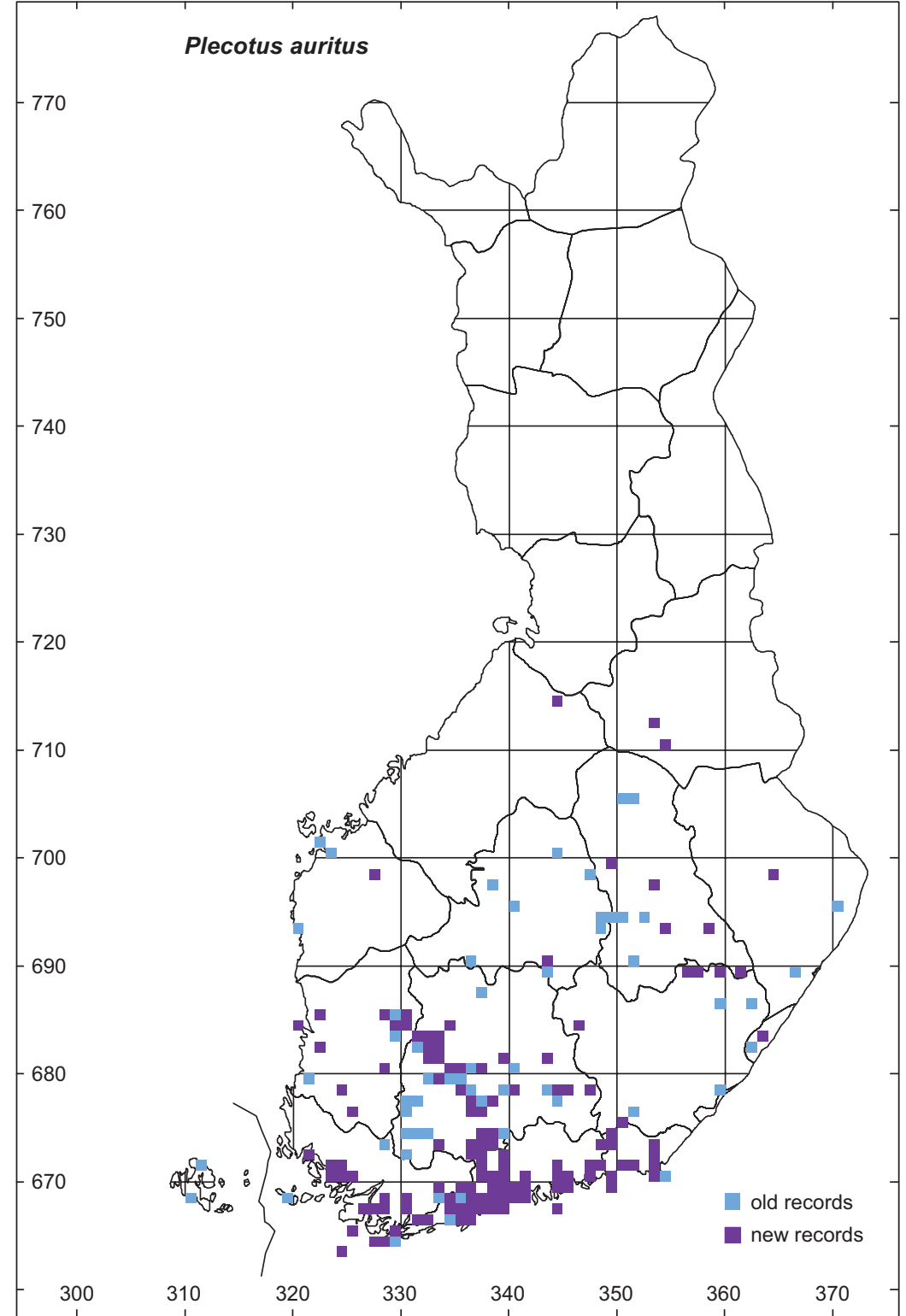

biogeographical provinces (Table 4), whereas three old records came from three provinces.

Abundance and status in Finland: Despite the growing number of bat surveys and detectors used, the parti-coloured bat has not been observed as often as other rare or migratory species. The species seems very rare and is most likely migrant. No records exist of this species breeding in Finland. However, Lundahl (1852) reported killing six specimens in a garden in August 1834 in Tampere; this relatively large number of individuals may refer to a colony. No observations of hibernating individuals exist, although one individual was found in November 1986 (stored as a museum specimen since its death). Another museum specimen was found dead in February 2011 at a bird ringing station; the time of the animal's death being unknown.

The parti-coloured bat is a strong flyer and a migratory species. The longest recorded movement was $1780 \mathrm{~km}$ (Markovets et al. 2004). In the 2010s in Finland, the species was very rarely 


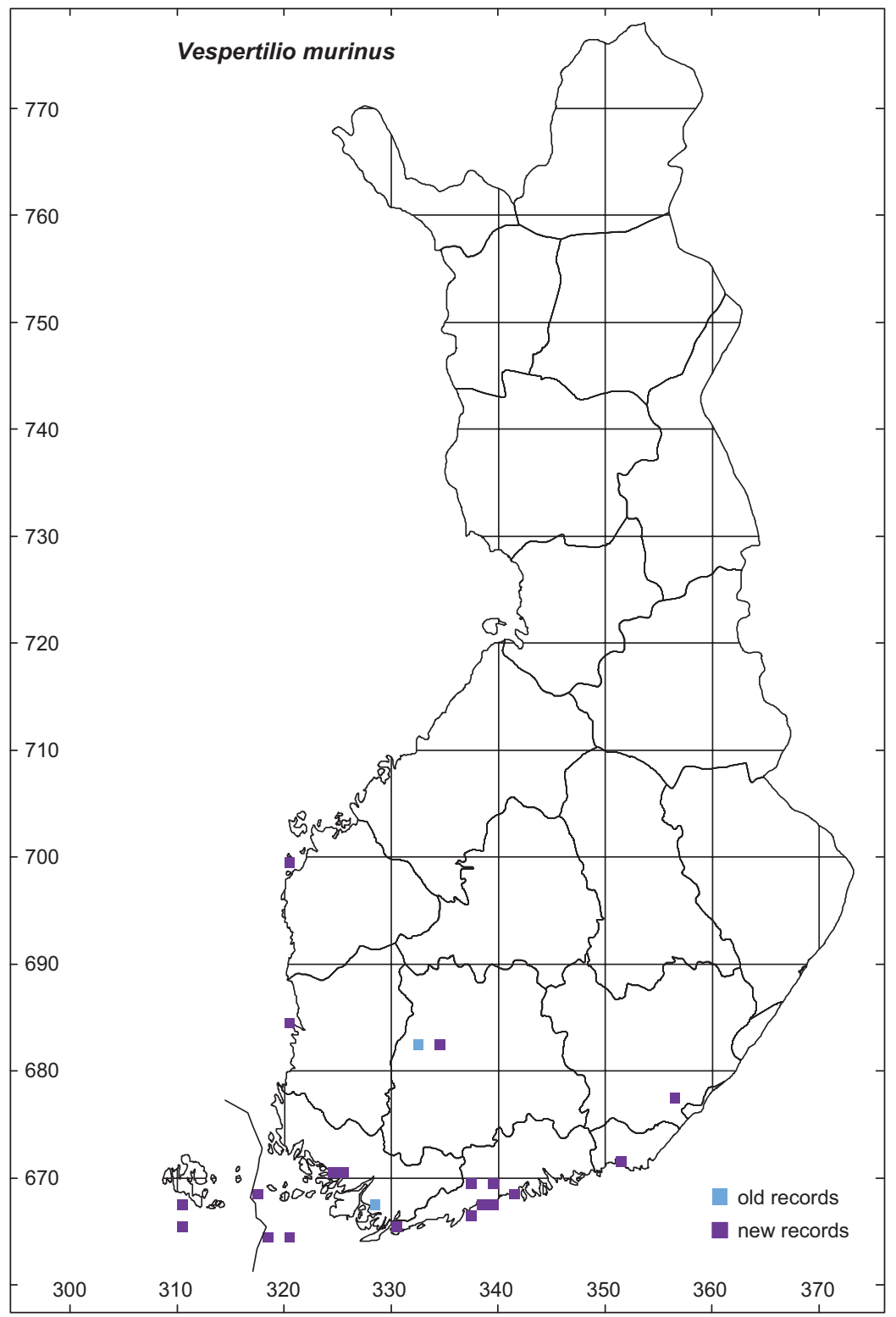

Fig. 18. Distribution of the parti-coloured bat in Finland.

recorded in bat migration monitoring and other surveys using passive detectors.

\section{Discussion}

\section{Quality of the data}

Most of the data used in this bat atlas was collated before 2014. As the amount of new bat observations is growing rapidly due to increas- ing bat survey and research activity, more data are yet to be published. Many professionals and amateurs often use passive detectors that can be left in the field for a longer time, due to the easy use and the significant decrease in the prices of these devices. Thus, there are large data sets from many locations. When made public, these data will most probably include records from new locations and further north than to date. This atlas thus presents the current knowledge also revealing gaps and need for further research. 
We collated data from different sources, with varying reliability. We evaluated the records, especially those of rare species, considering the species, type and location of the observation and how experienced the observers were. However, in many cases we had no access to primary data, for example the original detector recordings.

The evaluation of the reliability of the records varies with the species. For some species, a visual observation was considered reliable. For example, our data includes several visual observations of a large, highflying bat not supported by detector observation or photos. We classified these observations based on the description of size, colour and flight style, and accepted them as sufficiently detailed records of the noctule even though some of the observed bats might have been serotines. Concerning the whiskered bat and Brandt's bat, we only accepted records based on morphological identification. We also recognise the difficulties in the identification of Pipistrellus species, as there is variation and overlap in their echolocation calls. In most cases, we trusted the expertise of the surveyors although we could not assess the primary data for species identification.

\section{Changes in the species numbers}

The number of bat species recorded in Finland increased during the last decades, and even more species might be found in the near future. According to three bat atlases from the 1990s (Haukkovaara 1993, Stjernberg et al. 1993, Mitchell-Jones et al. 1999), the Finnish bat fauna comprised nine species until 2001. After 2001, further four species were added to the Finnish bat fauna: common pipistrelle, pond bat, soprano pipistrelle and serotine (see Table 1). This addition was mostly due to new technology, mainly bat detectors, and an increasing interest in bats among researchers and amateurs. For example, the first bat detector in Finland was used in 1982 while by 1999 there were 28 such detectors (third author's unpubl. data). In 2002, the Finnish Chiropterological Society was founded and has since worked actively to raise bat. Publications devoted to bats (e.g. de Jong et al. 1995, Lappalainen 2003) have also played a role in raising awareness. The first doctoral thesis on bats in Finland was published by Nyholm in 1965, and the following three theses were published not until the 2010s (Wermundsen 2010, Lilley 2012, Vesterinen 2015). The increasing interest in bats and activities related to bat research are detailed in national reports to the Agreement on the Conservation of Populations of European Bats (EUROBATS) (Kyheröinen et al. 2003, 2004, 2005, 2006, 2009, 2010, 2014, Kyheröinen \& Hyvärinen 2018). Changes in bat population sizes as well as changes in climate may also result in an increase in the number of bat species in Finland. Still, new bat species may be recorded in Finland, as ranges of some species in neighbouring countries expand. For example, the barbastelle (Barbastellus barbastellus), Leisler's bat (Nyctalus leisleri) and Alcathoe whiskered bat (Myotis alcathoe) occur in Sweden (Ahlén 2011) and may be detected in Finland as well. Observations of the barbastelle have increased in Sweden quite rapidly and the northernmost sites of occurrence are approximately at the same latitude as the Åland Islands.

Despite new species being recorded, the number of species in Finland decreases towards the north. This may be due to long and harsh winter and lack or very little darkness during summer nights in northern areas. Observation efforts are also much higher in the south than in the north. Many observations made in the north include very few details but have been accepted as the northern bat records. However, it is possible that some of those observations concern other species. For example, the particolored bat, which occurs very north in Norway, could also occur in Finnish Lapland.

\section{Changes in distributions}

The maps produced from our data compared with those of earlier studies (handbooks and atlases) are mostly similar for many species. However, for some species and in some biogeographical provinces the changes have been remarkable. For example, Nathusius' pipistrelle is now present in ten biogeographical provinces as opposed to two in old records. According to Ahlén (2011), the range and abundance of this 
species increased in Skåne (southern Sweden) and on Gotland. Migration patterns of Nathusius' pipistrelles in the Kvarken strait between Finland and Sweden are not yet known, and it is unclear from where in Finland individuals come to this area. Thus far, using radio-tracking Fritzén and Hägg (2019) found one individual that migrated from Finland to Sweden in autumn. Hence, more research on the migratory behaviour of this and other species is needed to clarify the migration paths and breeding areas of bats in Finland.

The species composition in northern Finland has changed. Daubenton's bat has been recorded further north, and there were records of Myotis mystacinus/brandtii from Lapland, though it is not known which of the two species is in question. Also in the southwestern areas and the Alland Islands, there are records of species new to the provinces. This is presumably due to increased research and survey activities in those areas. One example is from the island of Bergö, in Ostrobottnia Australis, where a survey carried out for a wind farm project produced data on four bat species new to the province (Vasko \& HagnerWahlsten 2010). Improved species identification and awareness of challenges it includes may also result in an increased numbers of new species records. Targeted survey trips to areas with no or little previous data can be very valuable in finding new locations of occurrence. Siivonen and Wermundsen (2008b) demonstrated this in their systematic surveys of river corridors in northern Finland, which produced many new records of Daubenton's bat. We thus encourage researchers and amateur bat observers to survey areas with few bat records, as well as regions north of the known ranges of different species.

No major differences in the species distributions could be detected when comparing with the near-by areas of the neighbouring countries. However, the distributions of Daubenton's bat, the whiskered bat and Brandt's bat extend further north in Finland than in Sweden (Ahlén 2011, EEA-ETC/BD 2019). Contrary to what our limited data indicate for Finland, in Scandinavia, the common pipistrelle seems rarer than the soprano pipistrelle (Ahlén 2011, Størkersen et al. 2014). The common pipistrelle is also uncommon in the Baltic states, being only locally present in Estonia (Tõrv 2014) and rare in Latvia (Pētersons
2014). In Sweden and Norway, the soprano pipistrelle is common and has extensive ranges in the southern parts of those countries (Ahlén 2011, Størkersen et al. 2014) while in Estonia it is rare (Tõrv 2014, Masing 2015).

\section{Future use of the data}

This study provides a review of data previously not available or not collated. As such, it can be used as a base material for future presentations of bat species distribution in Finland. We also encourage bat researchers and amateurs to publish their observations with details on the observation method and species identification and hence make the data available. This would greatly help future bat research and conservation. The Finnish Biodiversity Information Facility (www.laji.fi) offers an easy-to-use portal for observation-data uploading and for retriving data from many sources.

To fulfil obligations arising from legislation, agreements and the recently published Action Plan for the Conservation of All Bat Species in the European Union, robust monitoring of bats should be carried out. At the moment there is no country-wide monitoring system in Finland. Regional or local monitoring activities, for example hibernacula censuses and monitoring using bat detectors in summer, have been running for several years but their geographical coverage is insufficient. Thus no information on population trends is available. This makes for example reporting required by the Article 17 of the EU Habitats Directive complicated, as the data is deficient for assessment of the conservation status of most of the bat species. While bats may be harmed by intensive forestry and other land use practices causing habitat change and fragmentation, there is an urgent need for surveying occurrences of bats and monitoring their populations.

\section{Acknowledgements}

We are grateful to the following researchers, bat survey consultants and amateur bat workers who provided us with their observations: Ingemar Ahlén, Markus Ahola, Niclas 
Fritzén, Nina Hagner-Wahlsten, Janne Heinonen, Asko Ijäs, Esko Inberg, Saara Kattainen, Seppo Keränen, Karri Kuitunen, Emma Kosonen, Markku Lappalainen and others in the Turku Bat Club, Jyrki Lehto, Jarmo Markkanen, Timo Metsänen, Petri Nummi, Hanna Tuominen and Ville Vasko. Igor Popov provided information on the pond bat in the St. Petersburg area. Olli Haukkovaara compiled bat distribution data for the first two bat atlases. We thank the following nature survey companies that provided us with either their data or survey reports: BatHouse, Biologitoimisto Vihervaara, Faunatica, Ympäristösuunnittelu Enviro and Ympäristötutkimus Yrjölä. Besides the collection data of the Finnish Museum of Natural History Luomus (University of Helsinki), we also received bat specimen data in the collections of other museums. We thank Forssan Luonnonhistoriallinen Museo, Iisalmen luontomuseo, Kuopio Natural History Museum, Zoological Museum of the University of Oulu, Zoological Museum of the University of Turku and the biological collections of the University of Joensuu (now University of Eastern Finland) for providing bat specimen data. The bat ringers Nina Hagner-Wahlsten, Ari Karhilahti, Emma Kosonen, Veronika Laine, Markku Lappalainen, Pipsa Lappalainen, Thomas Lilley, Risto Lindstedt, Silva Sallamaa, Hanna Tuominen, Ville Vasko and Petteri Vihervaara are thanked for their ringing data. Sampo Kunttu, Tapani Lahti and Liisa Tuominen-Roto are thanked for extracting bat data from the databases of the Finnish Chiropterological Society, Finnish Museum of Natural History Luomus and SYKE, respectively. These organisations are thanked for granting permissions to use the data. Mervi Laitinen and Linda Kartano are thanked for preparing the maps. Sophie Aminoff, Maria Carrasco, Maarit Jokinen, Emmalotta Jääskeläinen, Laura Niinimäki, Seija Pulkkinen, Juhani Päivärinta and Sara Savolainen helped in digitising data. Laura Niinimäki also carried out field work in eastern Finland in 2010. Meri Lappalainen is thanked for proof-reading. An anonymus reviewer is thanked for valuable comments on the manuscript. Finally, we express our gratitude to the authors of the approximately 300 reports from which we extracted the bat data, as well as to those approximately 550 persons who provided their occasional observations. We also recognise the work of previous bat researchers and amateurs who laid the foundation for this atlas.

\section{References}

Sources marked with an asterisks $(*)$ contain information on bats with sufficient spatial accuracy and were used to create the distribution maps. These sources are mostly not cited in the text.

Ahlén, I. 2011: Fladdermusfaunan i Sverige. Arternas utbredning och status. Kunskapsläget 2011. — Fauna och Flora 106: 2-19.

*Ahlman, S. 2010: Nakkilan taajamaosayleiskaavan luontoselvitys 2010. - Ahlman Konsultointi ja suunnittelu. [https://nakkila.fi/wp-content/uploads/2018/11/Nakkilan-taajamaosayleiskaavan-luontoselvitys-2010_netti- laatu.pdf].

*Ahlman, S. 2011: Rauman koillisen teollisuusalueen lepakkoselvitys. - Ahlman Konsultointi ja suunnittelu. [https:// www.rauma.fi/wp-content/uploads/2016/12/002038_selvitys_lepakkoselvitys_0.pdf].

*Ahlman, S. 2012: Merikarvian Köörtilän tuulivoimapuiston lepakkoselvitys 2012. - Ahlman Konsultointi ja suunnittelu, Pöyry Finland Oy. [https://docplayer. fi/10709199-Poyry-finland-oy-merikarvian-koortilantuulivoima-puiston-lepakko-selvitys-2012-ahlman. html].

*Ahlman, S. 2013: Kurikan Lehtivuorten tuulivoimapuiston lepakkoselvitys 2013. - Ahlman Group Oy. [https:// www.ymparisto.fi/download/noname/\%7BA794C5F1E1F5-416F-9770-A43BDF594918\%7D/110015].

*Ahlman, S. 2013: Saarijärven Soidinmäen tuulivoimapuiston lepakkoselvitys 2013. - Ahlman Group Oy. [http:// docplayer.fi/25707480-Tuulivoimapuisto-soidinmaki-oy-saarijarven-soidinmaen-tuulivoimapuiston-lepakkoselvitys-2013-ahlman-group-oy.html].

*Ahlman, S. 2013: Vesannon Honkamäen tuulivoimapuiston lepakkoselvitys 2013. - Ahlman Group Oy, Pori, Tuulivoimapuisto Vöyrinkangas Oy.

*Ahlman, S. 2014: Kyyjärven Peuralinnan tuulivoimapuiston lepakkoselvitys 2014. - Ahlman Group Oy. [http:// www.paikkatieto.airix.fi/tietopankki/kyyjarvi/peuralinna/perusselvitykset/tuulivoimapuiston_lepakkoselvitys.pdf].

*Ahlman, S. \& Kinnunen, J. 2013: Konneveden Silmutmäen tuulivoimapuiston lepakko- ja kasvillisuusselvitys 2013. — Ahlman Group Oy. [http://www.konnevesi.fi/uploads/ lepakko-\%20ja\%20kasvillisuusselvitys.pdf].

*Aho, J. 1964: The autumn food of Asio f. flammeus Pontopp. in the vicinity of the city of Tampere, South Finland. - Annales Zoologici Fennici 1: 375-376.

*Airola-Kurvinen, K. 1997: Pohjanlepakon (Eptesicus nilssoni) habitaattijakaumasta napapiirillä. - M.Sc. thesis, Oulun yliopisto.

*Ala-Risku, T. 2014: Jämijärven kunta, Lautakankaan osayleiskaava. Yleiskaava-alueen luonnon nykytilan kuvaus. — T:mi Pohjanmaan Luontotieto, Kurikka.

Altringham, J. D. 2011: Bats - from evolution to conservation. - Oxford University Press.

American Society of Mammalogists 2019: Mammal diversity database. - Available at www.mammaldiversity.org.

*Anonymous 1931: Kokousselostuksia. Kokous 10.V.30. Luonnon Ystävä 35: 74-80.

*Anonymous 2011: Valkeakoski Koivuniemen asemakaavan laajennus 1. (23.1.2012) selostukseen liitetty luontoselvitys. - Valkeakosken kaupunki, Kaupunkisuunnittelu/ Kaavoitus. http://www.valkeakoski.fi/files/attachments/ kaavat/2012/koivuniemi_i/438_koivuniemi_laajennus_1_selostus_hyvaksytty.pdf

Baagøe, H. J. 1973: Taxonomy of two sibling species of bats in Scandinavia Myotis mystacinus and Myotis brandtii (Chiroptera). - Videnskabelige Meddelelser Dansk Naturhistorisk Forening 136: 191-216.

Barataud, M. 2015: Acoustic ecology of European bts. Species identification, study of their habitats and foraging behaviour. - Inventaires et biodiversité series, Museum 
national d'Histoire naturelle, Paris.

Barratt, E. M., Deaville, R., Burland, T. M., Bruford, M. W., Jones, G., Racey, P. A. \& Wayne, R. K. 1997: DNA answers the call of pipistrelle bat species. - Nature 387: 138-139.

Benda, P., Coroiu, I. \& Paunović, M. 2016: Pipistrellus pygmaeus. - The IUCN Red List of Threatened Species. [http://dx.doi.org/10.2305/IUCN.UK.2016-2.RLTS. T136649A21990234.en].

*Bergman, G. 1972: Isolepakko Kirkkonummen Mickelskärin Lövlandetissa. — Luonnon Tutkija 76: 148-149.

Bergman, G. \& Hackman, W. 1969: Accessions to the Zoological Museum, University of Helsinki (Helsingfors) in 1968-1969. - Memoranda Societatis pro Fauna et Flora Fennica 45: 155-157.

*Brander, T. 1949: Faunistiska iakttagelser i Kivijärvi-trakten i Urdiala (Ta). - Memoranda Societatis pro Fauna et Flora Fennica 25: 121-135.

*Brander, T. 1953: Om vertebratfaunan i mellersta Kyrkslätt (N). - Memoranda Societatis pro Fauna et Flora Fennica 29: 28-35.

*Brander, T. 1957: Eläintieteellisestä tutkimustyöstä Lounais-Hämeessä 1951-57. I. Selkärankaiset. — Luonais-Hämeen Luonto 3: 34-52.

*Brander, T. 1961: Eläintieteellisestä tutkimustyöstä Lounais-Hämeessä. III. Selkärankaiset, Vertebrata 1958-61. - Lounais-Hämeen Luonto 10: 27-39.

*Brander, T., Joki, J. \& Väre, A. 1961: Lounais-Hämeen selkärankaiset, Vertebrata. — Luonais-Hämeen Luonto 11: 55-63.

*Buddén, E. J. 1901: Lepakko vankeudessa. - Luonnon Ystävä 5: 1-3.

Buresh, I. [Буреш, И.] 1941: [Die Fledermäuse ziehen wie die Zugvögel]. - Knita LXI (2): 51-72. [In Bulgarian with German summary]

Chistyakov, D. V. 2002: Myotis dasycneme (Boie) pond bat. - In: Noskov, G. A. (ed.), Red Data Book of Nature of the Leningrad Region, vol. 3: Animals: 436-437. Biological Research Institute of the St Petersburg State University, St. Petersburg.

Coroiu, I. 2016a: Eptesicus nilssonii. — The IUCN Red List of Threatened Species. [http://dx.doi.org/10.2305/IUCN. UK.2016-2.RLTS.T7910A22116204.en.

Coroiu, I. 2016b: Myotis mystacinus. — The IUCN Red List of Threatened Species. [http://dx.doi.org/10.2305/IUCN. UK.2016-2.RLTS.T14134A22052250.en].

Coroiu, I. 2016c: Vespertilio murinus. - The IUCN Red List of Threatened Species. [http://dx.doi.org/10.2305/IUCN. UK.2016-2.RLTS.T22947A22071456.en].

Council Directive 92/43/EEC on the Conservation of natural habitats and of wild fauna and flora 1992. [http://eur-lex. europa.eu/LexUriServ/LexUriServ.do?uri=CELEX:319 92L0043:EN:NOT].

Csorba, G. \& Hutson, A. M. 2016: Nyctalus noctula. The IUCN Red List of Threatened Species. [http:// dx.doi.org/10.2305/IUCN.UK.2016-2.RLTS. T14920A22015682.en].

de Jong, J. 1994: Habitat use, home-range and activity pattern of the northern bat, Eptesicus nilssoni, in a hemiboreal coniferous forest. - Mammalia 58: 535-548. de Jong, J., Lokki, J. \& Stjernberg, T. 1995: Lepakot harrastukseksi! Nyt voit myös kuunnella niitä (Summary: Batting). - Linnut 30: 26-33.

Dechmann, D.K.N., Wikelski, M., Varga, K., Yohannes, E., Fiedler, W., Safi, K., Burkhard, W-D. \& O’Mara, M.T. 2014: Tracking Post-Hibernation Behavior and Early Migration Does Not Reveal the Expected Sex-Differences in a "Female-Migrating" Bat. — PLOS ONE 9(12): e114810, https://doi.org/10.1371/journal.pone.0114810.

Dietz, C. \& Kiefer, A. 2016: Bats of Britain and Europe. Bloomsbury Publishing Plc., United Kingdom.

Dietz, C., von Helversen, O. \& Nill, D. 2009: Bats of Britain, Europe and northeastern Africa. - A\&C Black, London.

EEA-ETC/BD 2019: Article 17 web tool. - European Environment Agency - European Topic Centre on Biological Diversity. [https://nature-art17.eionet.europa.eu/ article17/reports2012].

*Eischer, K. 2011: Vahingonlaukaus. Eli kertomus siitä, kuinka sattumalta voi syntyä eläintieteenhistoriaa. Lintuviesti 4: 24-25.

*Enviro Oy 2005: Kalajärvi II:n asemakaava-alueen luontoselvitys 2005. - Ympäristösuunnittelu Enviro Oy, Mikkeli.

*Enviro Oy 2005: Perusmäen-Viiskorven alueen luontoselvitys 2005. - Ympäristösuunnittelu Enviro Oy, Mikkeli. [https://www.esbo.fi/download/noname/\%7B35D6F 784-C0A2-450D-8D44-273BFF32D007\%7D/120024].

*Enviro Oy 2006: Espoonväylän vaikutusalueen luontoselvitys. - Ympäristösuunnittelu Enviro Oy, Mikkeli.

*Enviro Oy 2008: Espoon jätevedenpuhdistamon ympäristövaikutusten arviointi. Sijoituspaikkavaihtoehtojen luontoselvitys. - Ympäristösuunnittelu Enviro Oy, Mikkeli.

*Erkamo, V. 1944: Syysmyöhäinen yökkö. — Luonnon Ystävä 48: 98.

*Erkinaro, M. 2005: Lahden lepakot - kartoitus 2003 ja suuntaviivoja tulevaisuuteen. — Valvonta- ja ympäristökeskuksen tiedonantoja sarja A2/2005.

*Erkinaro, M. 2006: Aulangonniemen lepakkokartoituksen 2006 alustavat tulokset. - Hämeenlinnan seudun luonnonsuojeluyhdistys ry., Hämeenlinna.

*Erkinaro, M. 2010: Lahden kaupungin lepakkokartoitus yleiskaavaa varten 2009. - Available at https://www. lahti.fi/PalvelutSite/KaavoitusSite/Documents/Selvitykset $\% 20 \mathrm{ja} \% 201 \% \mathrm{C} 3 \% \mathrm{~A} 4 \mathrm{ht} \% \mathrm{C} 3 \%$ B6tiedot/LepakkoselvitysRaportti2009.pdf.

*Erkinaro, M. \& Nieminen, M. 2008: Nurmijärven Mäntymäen lepakkokartoitus 2008. — Faunatica Oy, Espoo.

*Erkinaro, M. \& Nieminen, M. 2008: Porvoon Kilpilahden lepakkokartoitus 2008. - Faunatica Oy, Espoo.

*Erkinaro, M. \& Nieminen, M. 2008: Vammalan Houhajärven rantaosayleiskaava-alueen lepakoiden perus- ja jatkoselvitys 2007. — Faunatica Oy, Espoo.

*Erkinaro, M. \& Nieminen, M. 2009: Kotkan Hietasen sataman lepakoiden perusselvitys 2008-2009. - Faunatica Oy, Espoo.

*Erkinaro, M. \& Nieminen, M. 2009: Lepakkoselvitykset neljällä Loviisan asemakaava-alueella vuonna 2009. Muistio 3.11.2009. — Faunatica Oy, Espoo. [https:// 
docplayer.fi/26636547-Lepakkoselvitykset-neljallaloviisan-asemakaava-alueella-vuonna-mikko-erkinaromarko-nieminen.html].

*Erkinaro, M. \& Nieminen, M. 2009: Loviisan Harmaakallion kevään 2009 talvipiilo- ja kevätsoidintutkimusten alustavat tulokset ja kaavoitusrajaussuositukset. - Faunatica Oy, Espoo. [https://docplayer.fi/26636547-Lepakkoselvitykset-neljalla-loviisan-asemakaava-alueella-vuonna-mikko-erkinaro-marko-nieminen.html].

*Erkinaro, M. \& Nieminen, M. 2010: Marja-Vantaan lepakkokartoitus vuonna 2009. - Faunatica Oy, Espoo. [https://www.vantaa.fi/instancedata/prime_product_julkaisu/vantaa/embeds/vantaawwwstructure/119025_marja-vantaan lepakkokartoitus 2009.pdf].

*Erkinaro, M., Nieminen, M. \& Sundell, P. R. 2009: Lepakkoselvitys Loviisan asemakaava-alueilla vuonna 2008. - Faunatica Oy, Espoo.

Fairon, J. 1967: Vingt-cinq années de baguage des chiroptères en Belgique. - Bulletin de l'Institut Royal des Sciences Naturelles de Belgique 43: 1-37.

*Finnish Biodiversity information facility (FinBIF). Available at http://tun.fi/HBF.37325.

*Forsius, I. 1921: Muistiinpanoja Nuorttijoella Lkem esiintyvistä imettäväisistä ja kaloista. - Luonnon Ystävä 25: 164-166.

*Frey, R. 1918: Mötet den 7 december 1918, Societas pro Fauna et Flora Fennica. - Meddelanden af Societas pro Fauna et Flora Fennica 45: 67.

*Friman, M., Hagner-Wahlsten, N., Soini, P. \& Yrjölä, R. 2007: Luontoselvitys Vermon alueella. — Ympäristötutkimus Yrjölä Oy, Klaukkala.

*Friman, M., Hagner-Wahlsten, N., Helminen, S.-L., Jokinen, K., Karlsson, R. \& Yrjölä, R. 2010: Ketunkorven luontoselvitykset 2010. — Ympäristötutkimus Yrjölä Oy, Klaukkala, BatHouse, Kauniainen. [https://www.espoo. fi/download/noname/\%7B46F6A8D0-CD09-4F9FB155-5BB50EE2849A\%7D/99097].

Fritzen, N. 2014: KvarkenBats — Migrerande fladdermöss i Kvarken. - OA Natur 16: 30-41.

Fritzen, N. 2015: KvarkenBats - nya resultat som stöder hypotesen om kvarkenöverskridande fladdermusmigration. - OA Natur 17: 14-27.

Fritzén, N. \& Hägg, J. 2019: Valsörarnas biologiska station — verksamhetsberättelse för år 2018. _ OA Natur 21: $3-15$.

*Haakana, H. 2011: Kiteen Meijerin ja ranta-alueen suunnittelualueen lepakkokartoitus. — TOIMI -ympäristöalan asiantuntijaosuuskunta, Joensuu.

*Haakana, H. 2012: Joensuun keskustan osayleiskaava-alueen lepakkokartoitus. — TOIMI -ympäristöalan asiantuntijaosuuskunta, Joensuu.

*Haakana, H. \& Vuorio, V. 2010: Joensuun Reijolan osayleiskaava-alueen lepakkolajiston kartoitus. - Julkaisuja 2/2010, Joensuun kaupunki.

Hagner, N. 1987: Rabies hos fladdermöss samt dess eventuella förekomst $i$ Finland. - M.Sc. thesis, Helsingfors universitet.

*Hagner-Wahlsten, N. 2006: Espoon Näkinmetsän kaava-alueen lepakkokartoitus 2006. — VVO/Ympäristötutkimus Yrjölä Oy, Klaukkala.
*Hagner-Wahlsten, N. 2006: Kauniaisten lepakkokartoitus 2006. - BatHouse, Kauniainen. [https://www.kauniainen.fi/files/850/raportti_Kauniaisten lepakkokartoitus_2006.pdf].

*Hagner-Wahlsten, N. 2006: VT 7 (E18) parantaminen välillä Loviisa-Kotka, yleissuunnitelmaan liittyvien luontoselvitysten yhteydessä tehty Ahvenkosken alueen lepakkoselvitys 2006. — BatHouse, SITO, Kaakkois-Suomen tiepiiri.

*Hagner-Wahlsten, N. 2007: Kotkan Räskin-Soininlaakson osayleiskaava-alueen lepakkokartoitus 2007. — BatHouse, Kauniainen.

*Hagner-Wahlsten, N. 2007: Pyhtään Heinlahden osayleiskaava-alueen lepakkoselvitys 2007. — BatHouse, Kauniainen.

*Hagner-Wahlsten, N. 2008: Espoon Kulmakorven alueen lepakkoselvitys 2008. - BatHouse, Kauniainen.

*Hagner-Wahlsten, N. 2008: Espoon Muuttolinnunmäen kaava-alueen lepakkokartoitus. - BatHouse, Kauniainen.

*Hagner-Wahlsten, N. 2009: Lausunto lepakkoselvityksestä Kotkan Uusikylän alueella. - BatHouse, Kauniainen.

*Hagner-Wahlsten, N. 2009: Lepakoiden talvi-inventointi VT7 moottoritiehankkeeseen liittyen välillä HaminaVaalimaa. - BatHouse, Kauniainen.

*Hagner-Wahlsten, N. 2009: Mikkelin jätevedenpuhdistamojen sijoituspaikkojen lepakkoselvitys 2009. — BatHouse, Kauniainen.

*Hagner-Wahlsten, N. 2010: Jokelan (Kalajoki) ja Mäkikankaan (Pyhäjoki) tuulipuistoalueiden lepakkoselvitys 2010. - BatHouse, Kauniainen. [http://docplayer. fi/105294855-Jokelan-kalajoki-ja-makikankaan-pyhajoki-tuulipuistoalueiden-lepakkoselvitys-2010.html].

*Hagner-Wahlsten, N. 2011: Hangon Casinon ympäristön, Puistovuoren lähivirkistys- ja Plagenin alueen lepakkoselvitys 2011. - BatHouse, Kauniainen. [http:// docplayer.fi/1191217-Hangon-casinon-ympariston-puistovuoren-lahivirkistys-ja-plagenin-alueen-lepakkoselvitys-2011.html].

*Hagner-Wahlsten, N. 2011: Lepakoiden talvi-inventointi kahdessa bunkkerissa Virolahden Pajulahden asemakaava-alueella talvella 2011 ja lepakoiden kesäaikaisen kartoituksen tarpeen arviointi. - BatHouse, Kauniainen.

*Hagner-Wahlsten, N. 2012: Raaseporin Dragsvikin asemakaava-alueen lepakkoselvitys 2012. — BatHouse, Kauniainen.

*Hagner-Wahlsten, N. 2013: Nurmijärven Kyläpään lepakkokartoitus 2013. - BatHouse, Kauniainen. [http://m. nurmijarvi.fi/filebank/9071-4_9_Nurmijarven_Kylanpaan_lepakkokartoitus_2013.pdf].

*Hagner-Wahlsten, N., Helminen, S.-L., Santaharju, J. \& Yrjölä, R. 2008: Nepperi II kaava-alueen luontoselvitykset 2008. - Ympäristötutkimus Yrjölä Oy, Klaukkala.

*Hagner-Wahlsten, N. \& Karlsson, R. 2009: Pirkkalan kaava-alueen lepakkoselvitys 2009. — BatHouse, Kauniainen. [https://www.pirkkala.fi/site/assets/files/9459/pirkkalan_lepakot_2009_lopullinen.pdf].

*Hagner-Wahlsten, N. \& Karlsson, R. 2010: Seurasaaren lepakkoselvitys 2009. - BatHouse, Kauniainen. [https:// www.hel.fi/hel2/hkr/julkaisut/2010/Seurasaaren_lepa- 
kkoselvitys_2009.pdf].

*Hagner-Wahlsten, N. \& Karlsson, R. 2010: Tervalammen osayleiskaava-alueen lepakkoselvitys 2010. — BatHouse. Kauniainen.

*Hagner-Wahlsten, N. \& Karlsson, R. 2011: Lepakkoselvitys Virolahden Pajulahden asemakaava-alueella talvella ja kesällä 2011. — BatHouse, Kauniainen. [https://www. yumpu.com/fi/document/read/20227758/lepakkoselvitys-virolahden-virolahti].

*Hagner-Wahlsten, N. \& Karlsson, R. 2011: Pyhtään Sammalkallion lepakkoselvitys 2011. — BatHouse, Kauniainen.

*Hagner-Wahlsten, N. \& Kyheröinen, E.-M. 2005: Haminan kantakaupungin, Vilniemen ja Summan jokilaakson lepakkokartoitus. Kartoitusraportti. — Ympäristösuunnittelu Enviro Oy, Mikkeli.

*Hagner-Wahlsten, N. \& Kyheröinen, E.-M. 2008: First observation of breeding Nathusius' pipistrelle (Pipistrellus nathusii) in Finland. - Memoranda Societatis pro Fauna et Flora Fennica 84: 36-40.

*Hagner-Wahlsten, N., Santaharju, J., Vaskelainen, E., Virrankoski, S.-L. \& Yrjölä, R. 2006: Luontoselvitys Espoon Kallvik-Muulon asemakaava-alueelta. Ympäristötutkimus Yrjölä Oy, Klaukkala.

*Haukkovaara, O. 1993: Lepakkokartat. — Nisäkäsposti 33: $1-38$.

*Haukkovaara, O. 1997: Suomen ensimmäinen lepakoidensuojelualue. - Luonnon Tutkija 101: 34-35.

*Haukkovaara, O. 2002: Alustavat lepakkoinventoinnit Kanta-Hämeessä 2002, painottuen ripsisiipan (Myotis nattereri) etsintään. - Hämeen ympäristökeskus.

*Haukkovaara, O. 2007: Heritynniemen lepakkoinventointi 2006-2007. - Valkeakosken kaupunki.

Haupt, M., Menzler, S. \& Schmidt, S. 2006: Flexibility of habitat use in Eptesicus nilssonii: does the species profit from anthropogenically altered habitats? - Journal of Mammalogy 87: 351-361.

Havekost, H. 1960: Die Beringung der Breitflügelfledermaus (Eptesicus serotinus Schreber) im Oldenburger Land. Bonner Zoologische Beiträge 11, Sonderheft: 222-223.

Heikinheimo, O. \& Raatikainen, M. 1971: Paikan ilmoittaminen Suomesta talletetuissa biologisissa aineistoissa [Ortbeteckning för biologiskt material tillvarataget i Finland. The recording of localities of biological finds in Finland]. - Annales Entomologici Fennici 37(1a): 1-27. [In Finnish with Swedish and English summaries].

Heikinheimo, O. \& Raatikainen, M. 1981: Ruutukoordinaattien ja paikannimien käyttö Suomessa [Användning av rutkoordinater och ortnamn i Finland. Grid references and names of localities in the recording of biological finds in Finland]. - Notulae Entomologicae 61: 133154. [In Finnish with Swedish and English summaries].

*Heikkinen, T. 2009: Seminaarinmäen luontoarvot — kooste tehdyistä selvityksistä. — Jyväskylän kaupunki.

*Hellstedt, P. 2006: Toijalan satama-alueen lepakkokartoitus 2006. — Toijalan kaupunki. [https://docplayer. fi/7865784-Toijalan-satama-alueen-lepakkokartoitus2006-paavo-hellstedt.html].

*Hellstedt, P. 2008. Tampereen Saarenmaantien alueen lepakkokartoitus 2008. — Tampereen kaupunki. [https:// www.tampere.fi/ytoteto/aka/nahtavillaolevat/8258/selvitykset/8258_lepakkokartoitus.pdf].

*Hellstedt, P. 2008: Pirkkalan Linnankorven alueen lepakkokartoitus 2008. - Pirkkalan kunta.

*Hellstedt, P. 2008: Tampereen Ruskon alueen (8099 ja 8190) lepakkokartoitus 2008. — Tampereen kaupunki. [https:// docplayer.fi/50556056-Tampereen-ruskon-alueen-8099ja-8190-lepakkokartoitus-paavo-hellstedt.html].

*Hellstedt, P. 2009. Vuoreksen alueen lepakoiden talvehtimiskartoitus 2009. - Tampereen kaupunki.

*Hellstedt, P. 2010: Ikaalisten Kalmaanniemen II ja Patrakan alueiden lepakoiden lisääntymis- ja levähdysalueiden selvitys 2010. - Ikaalisten kaupunki.

*Hellstedt, P. \& Reponen, K. 2009: Mustasaaren Raippaluodon saariston Bredskäretin, Storträsketin ja Kåtöbrunnenin alueiden lepakkokartoitus heinäkuussa 2009. - Mustasaaren kunta.

*Hellstedt, P., Nieminen, M. \& Reponen, K. 2009: Mustasaaren Raippaluodon tuulipuiston suunnittelualueen lepakkokartoitus vuonna 2009. - Faunatica Oy, Espoo.

*Helminen, S.-L., Soini, P., Hagner-Wahlsten, N. \& Yrjölä, R. 2007: Selvitys Nupurinkallion selvitysalueelta. Ympäristötutkimus Yrjölä Oy, Klaukkala.

*Herrero, A. 2010: Holmanpuisto II kaava-alueen lepakkotarkastus 2009. Lisäselvitys 2010. — Espoon kaupunki, kaupunkisuunnittelukeskus, Sito Oy, Luontotieto Keiron Oy.

*Hertteli, P. 2013: Oulainen - Maaselänkangas. Lepakkoselvitys. - Ramboll, Lahti.

*Hiekkala, P. \& Nyman, J. 2008: Vaasan Wärtsilän suunnittelualueen lepakkokartoitus 2008. — Vaasan kaupunki.

*Honkala, J. \& Kyheröinen, E.-M. 2008: Siiri II, luontoselvitys. - Hämeenlinnan kaupungin kaavoitustoimisto.

*Honkala, J. \& Kyheröinen, E.-M. 2009: Vanajanlinnan luontoselvitys 2009. - Hämeenlinnan kaupungin kaavoitustoimisto.

Hutson, A. M., Aulagnier, S. \& Spitzenberger, F. 2008a: Myotis nattereri. - The IUCN Red List of Threatened Species. [http://dx.doi.org/10.2305/IUCN.UK.2008. RLTS.T14135A4405996.en].

Hutson, A. M., Spitzenberger, F., Aulagnier, S., Alcaldé, J. T., Csorba, G., Bumrungsri, S., Francis, C., Bates, P., Gumal, M., Kingston, T. \& Benda, P. 2008b: Eptesicus serotinus. - The IUCN Red List of Threatened Species. [http://dx.doi.org/10.2305/IUCN.UK.2008.RLTS. T7911A12867244.en].

Hutson, A. M., Spitzenberger, F., Aulagnier, S., Coroiu, I., Karataş, A., Juste, J., Paunovic, M., Palmeirim, J. \& Benda, P. 2008c: Pipistrellus pipistrellus. - The IUCN Red List of Threatened Species. [http://dx.doi. org/10.2305/IUCN.UK.2008.RLTS.T17317A6968203. en].

Hutson, A. M., Spitzenberger, F., Aulagnier, S., Coroiu, I., Karataş, A., Juste, J., Paunovic, M., Palmeirim, J. \& Benda, P. 2008d: Plecotus auritus. - The IUCN Red List of Threatened Species. [http://dx.doi.org/10.2305/ IUCN.UK.2008.RLTS.T17596A7154745.en].

Hutson, A. M., Spitzenberger, F., Coroiu, I., Aulagnier, S., Juste, J., Karataş, A., Palmeirim, J. \& Paunović, M. 2008e: Myotis brandtii. — The IUCN Red List of 
Threatened Species. [http://dx.doi.org/10.2305/IUCN. UK.2008.RLTS.T14125A4397500.en].

Hutterer, R., Ivanova, T., Meyer-Cords, C. \& Rodrigues, L. 2005: Bat migrations in Europe: a review of banding data and literature. - Naturschutz und Biologische Vielfalt Heft 28.

*Hyytiäinen, R. \& Virtanen, T. 2012: Pieksämäen vanhan ratapiha-alueen luontoselvitys 2012. — Biologitoimisto Vihervaara.

*Hämäläinen, A. 2011: Näsen kartanon tuulivoimapuiston lepakkoselvitys. - Ramboll, Lahti.

*Hänninen, P. 1987: Batmanin pikkuserkku vieraili Suomessa. - Nuorten Luonto 4: 45.

*Häyhä, T., Hagner-Wahlsten, N., Helminen, S.-L. \& Yrjölä, R. 2007: Hongiston asemakaava-alueen maisema- ja luontoselvitys 2007. — T:mi Teppo Häyhä, BatHouse \& Ympäristötutkimus Yrjölä Oy, Klaukkala.

Iso-Iivari, L. 1975: Vertebrates of Inari Lapland. - Kevo Notes 1: 1-19.

IUCN 2019: The IUCN Red List of Threatened Species, ver. 2019-2. - Available at https://www.iucnredlist.org.

*Jokinen, K., Friman, M., Helminen S.-L., Hagner-Wahlsten, N. \& Yrjölä, R. 2009: Espoon Ruukinrannan luontoselvitykset 2009. - Ympäristötutkimus Yrjölä Oy, Klaukkala, BatHouse, Kauniainen.

*Jokinen, K., Hagner-Wahlsten, N., Helminen, S.-L. \& Yrjölä, R. 2009: Espoon Suurpellon itäosan luontoselvitykset 2009. - Ympäristötutkimus Yrjölä Oy, BatHouse.

*Jokinen, K., Karlsson, R. \& Hagner-Wahlsten, N. 2010: Siuntion Marseuddenin luontoselvitykset 2010. Ympäristötutkimus Yrjölä Oy, Klaukkala, BatHouse, Kauniainen.

Jones, G. \& Barrat, E. M. 1999: Vespertilio pipistrellus Schreber, 1774 and V. pygmaeus Leach, 1825 (currently Pipistrellus pipistrellus and P. pygmaeus; Mammalia, Chiroptera): proposed designation of neotypes. - The Bulletin of Zoological Nomenclature 56: 182-186.

*Jutila, H. \& Metsänen, T. 2010: Hämeenlinnan Äikäälän luontoselvitys. - Hämeenlinnan ympäristöjulkaisuja 13.

Jäppinen, J. 1987: Viiksisiippojen (Myotis mystacinus) talvehtimisesta. - Luonnon Tutkija 91: 156-157.

*Kaikusalo, A. \& Sirjola, E. 1980: Inarin nisäkkäät. — Nisäkäspostia 13: 1-12.

*Kaikusalo, A. \& Skarén, A. 1977: Nisäkäshavaintoja. — Nisäkäspostia 7: 1-5

*Kaisila, J. 1972: Isolepakkoja Köökarissa. - Luonnon Tutkija 76: 149 .

*Karlsson, R. \& Hagner-Wahlsten, N. 2012: Nurmijärven Klaukkalan OYK-alueen lepakkoselvitys 2010 \& 2012. - BatHouse, Kauniainen.

*Kinnunen, H., Tidenberg, E.-M. \& Pitkänen, M. 1998: Helsingin lepakkoatlas. Lepakkohavainnot vuodelta 1997. - Helsingin kaupungin ympäristökeskus. Helsinki.

Kivirikko, K. E. 1940: Suomen selkärankaiset. Vertebrata Fennica. - WSOY, Porvoo-Helsinki.

*Klemola, H. 2008: Turku, Hepokulta. Luontoselvitys. T:mi Hannu Klemola, Littoinen. [https://docplayer. fi/349540-Turku-hepokulta-luontoselvitys-tmi-hannu-klemola-2008.html].

Kosonen, E. 2008: Lepakkojen salatut elämät. Pohjanle- pakkoyhdyskunnan radiotelemetriatutkimus. - Turun ammattikorkeakoulun raportteja 74: 1-26.

*Kosonen, E. 2009: Lepakkoselvitys "Kaivokatu 11". Raportti Varsinais-Suomen ELY-keskukselle, Turku.

*Kosonen, E. 2012: Etelänlepakko yllätti. — Suomen Luonto 71: $30-31$.

*Kuitunen, K. 2011: Fortumin Imatran voimalaitosalueen luontoselvitys 2011. — T:mi Ympäristötutkimus Kuitunen, Lappeenranta. [https://www.imatra.fi/sites/default/ files/atoms/files/Fortumin \%20Imatran \%20voimalaitosalueen $\% 201$ luontoselvitys $\% 202011$.pdf].

*Kuitunen, K. 2012: Lappeenrannan Munteron linnusto- ja lepakkoselvitys vuonna 2012. — Pöyry Finland Oy. Turku. [https://docplayer.fi/8926154-Raportti-16usp0105-20-8-2012-lappeenrannan-kaupunki-munteron-asemakaava-luontoselvitys.html].

*Kyheröinen, E.-M. 2004: Haminan ohitustiehankkeen lepakkokartoitus. Valtatien 7 (E18) parantaminen Haminan kohdalla. Yleissuunnitelma, Oheisraportti. — Ympäristösuunnittelu Enviro Oy, Mikkeli.

Kyheröinen, E.-M. 2004: Lepakoiden (Chiroptera: Vespertilionidae) elinympäristönvalinta ja saalistusaktiivisuus Etelä-Hämeen maisemamosaiikissa. - M.Sc. thesis, Bio- ja ympäristötieteiden laitos, Helsingin yliopisto.

*Kyheröinen, E.-M. 2005: Kauklahden asemakaava-alueiden lepakkokartoitus - Espoon kaupunkisuunnittelukeskus.

Kyheröinen, E.-M. 2008: Feeding habitats of brown longeared bats (Plecotus auritus) in southern Finland. - In: Hutson, A. M. \& Lina, P. H. C. (eds.), XIth European Bat Research Symposium, 18-22 August, 2008, ClujNapoca, Romania. Volume of Abstracts: 85. Universitatea Babeş-Bolyai.

*Kyheröinen E.-M., Niiranen S., Santaharju J., Virrankoski S.-L. \& Yrjölä R. 2006: Luonto- ja maisemaselvitys Tuusulan Tuomalansuon alueelta. — Ympäristötutkimus Yrjölä Oy, Klaukkala. [https://www.tuusula.fi/ attachments/text_editor/6278.pdf].

Kyheröinen, E.-M. \& Hyvärinen, E. 2018: EUROBATS National implementation report. - Inf.EUROBATS. MoP8.18, https:/www.eurobats.org/sites/default/files/ documents/pdf/Meeting_of_Parties/Inf.MoP8_.18_ NIR_Finland.pdf.

Kyheröinen, E.-M., Liukko, U.-M. \& Stjernberg, T. 2013: Bats in the far north - updated distributions of bats in Finland. - Bat Research News 54: 145-146.

Kyheröinen, E.-M., Osara, M. \& Stjernberg, T. 2003: Agreement on the conservation of bats in Europe: update to the national implementation report of Finland. - Inf.EUROBATS.AC8.23, http://www.eurobats.org/sites/default/files/ documents/pdf/National_Reports/nat_rep_Fin_2003.pdf.

Kyheröinen, E.-M., Osara, M. \& Stjernberg, T. 2004: Agreement on the conservation of bats in Europe (EUROBATS): Update to the national implementation report of Finland. - Inf.EUROBATS.AC9.27, http://www. eurobats.org/sites/default/files/documents/pdf/National_ Reports/nat_rep_Fin_2004.pdf.

Kyheröinen, E.-M., Osara, M. \& Stjernberg, T. 2005: Agreement on the conservation of bats in Europe: update to the national implementation report of Finland. - Inf. 
EUROBATS.AC10.21, http://www.eurobats.org/sites/ default/files/documents/pdf/National_Reports/nat_rep_ Fin 2005.pdf.

Kyheröinen, E.-M., Osara, M. \& Stjernberg, T. 2006: Agreement on the conservation of populations of European bats: national implementation report of Finland. - Inf. EUROBATS.MoP5.19, http://www.eurobats.org/sites/ default/files/documents/pdf/National Reports/nat rep Fin 2006.pdf.

Kyheröinen, E.-M., Osara, M. \& Stjernberg, T. 2009: Agreement on the conservation of populations of European bats: update to the national implementation report of Finland. - Inf.EUROBATS.AC14.11, http://www. eurobats.org/sites/default/files/documents/pdf/National_ Reports/nat_rep_Fin_2009.pdf.

Kyheröinen, E.-M., Osara, M. \& Stjernberg, T. 2010: Agreement on the conservation of populations of European bats: national implementation report of Finland. - Inf. EUROBATS.MoP6.18, http://www.eurobats.org/sites/ default/files/documents/pdf/National_Reports/nat_rep Fin_2010.pdf.

Kyheröinen, E.-M., Osara, M. \& Stjernberg, T. 2014: Agreement on the conservation of populations of European bats: national implementation report of Finland. Inf.EUROBATS.MoP7.17, http://www.eurobats.org/ sites/default/files/documents/pdf/National_Reports/Inf. MoP7_.17-NationalImplementationReportofFinland. doc.

*Kyheröinen, E.-M. \& Pimenoff, S. 2008: Espoonjoen lepakkoselvitys. - Espoon ympäristölautakunnan julkaisusarja 3/08.

Kyheröinen, E.-M., Vasko, V., Hagner-Wahlsten, N., Inberg, E., Kosonen, E., Lappalainen, M., Lilley, T., Lindstedt, R., Liukko, U.-M. \& Norrdahl, K. 2009: Bat migration studies in Finland 2008. - In: 1st International Symposium on Bat Migration: 61. Leibniz Institute for Zoo and Wildlife Research (IZW), Berlin.

*Lammi, E. 2010: Holmanpuiston asemakaava-alueen luontoselvitys. - Ympäristösuunnittelu Enviro Oy, Mikkeli.

*Lammi, E. 2011: Espoonväylä-Lugnetin alueen luontoselvitys. - Ympäristösuunnittelu Enviro Oy, Mikkeli. [https://docplayer.fi/49914943-Espoonvaylan-lugnetin-alueen-luontoselvitys.html].

*Lammi, E. 2012: Bergön ja Fridheminkallion luontoselvitys. - Ympäristösuunnittelu Enviro Oy, Mikkeli.

*Lammi, E., Routasuo, P. \& Vauhkonen, M. 2014: Pajalan hautausmaan alueen luontoselvitys. - Ympäristösuunnittelu Enviro Oy, Mikkeli.

*Lappalainen, M. 2003: Lepakkomuumion arvoitus ja muita Pipistrellus-lepakoiden määrityspulmia. - Luonnon Tutkija 4: 131-133.

Lappalainen, M. 2003: Lepakot — salaperäiset nahkasiivet, 2. painos. - Tammi, Helsinki.

*Lappalainen, M. 2008: Suomeen uusi nisäkäslaji: Etelänlepakko ilmestyi Hankoon. - Suomen Luonto 67: 33.

*Lappalainen, M. \& Vuorisalo, T. 1996: Kaikenkarvaiset kaupunkilaiset. Turun nisäkkäät. — TS-Yhtymä Oy, Turku.

*Lehmann, R. 1983a: Bat research in southern Finland. Faunistic notes from summer 1982 (Chiroptera, Vesper- tilionidae). - Memoranda Societatis pro Fauna et Flora Fennica 59: 155-160.

*Lehmann, R. 1983b: Suomen ensimmäinen pikkulepakko. —Luonnon Tutkija 87(2): 76.

Lehmann, R. 1983-1984: Myotis mystacinus (Kuhl, 1819) and Myotis brandti (Eversmann, 1845) in Finland. Myotis 21-22: 96-101.

*Lehvola, H. 2012: Hartolan Purnuvuoren lepakkoselvitys. - Ramboll, Lahti. [https://docplayer.fi/2582715-Ilmatar-hartolan-purnuvuoren-lepakkoselvitys.html].

*Lehvola, H. \& Osmala, E. 2013: Hennan asemakaavaalueen luontoselvitykset 2013. - Ramboll, Lahti.

*Lehvola, H. \& Urho, K. 2013: Outokummun keskustan osayleiskaavan luontoselvitys: linnusto ja lepakot. Ramboll, Lahti.

*Lilley, T. \& Nieminen, M. 2013: Hämeenlinnan asemakaava-alueiden lepakkoselvitys 2013. - Faunatica Oy, Espoo. [https://www.hameenlinna.fi/wp-content/ uploads/2019/03/Lepakkoselvitys_raportti_2013.pdf].

Lilley, T. 2012: Butyltin compounds in the food web: impacts on chironomids and Daubenton's bats. - Annales Universitatis Turkuensis A II 273: 1-51.

Lina, P. H. C. 2016: Common names of European bats. EUROBATS Publication Series 7, UNEP/EUROBATS Secretariat, Bonn, Germany.

*Lindstedt, R. \& Laine, V. 2013: Lampisiippa on erotettavissa maastossa vesisiipasta. - Luonnon Tutkija 117: $55-58$.

Liukko, U.-M., Henttonen, H., Kauhala, K., Kojola, I., Kyheröinen, E.-M. \& Pitkänen, J. 2019: Mammals. - In: Hyvärinen, E., Juslén, A., Kemppainen, E., Uddström, A. \& Liukko, U.-M. (eds.) 2019: The Red List of Finnish Species: 571-576. Ministry of the Environment \& Finnish Environment Institute, Helsinki.

*Lundahl, C. 1852: Bidrag till mellersta Finlands micromammalogi. - Notiser, Sällskapet pro Fauna et Flora Fennica. Bihang till Acta Societatis Scientiarum Fennicae II: 287-299.

Lundy, M., Montgomery, I. \& Russ, J. 2010: Climate changelinked range expansion of Nathusius' pipistrelle bat, Pipistrellus nathusii (Keyserling \& Blasius, 1839). Journal of Biogeography 37: 2232-2242.

*Luontotieto Keiron Oy 2007: Espoon Högnäs. Luontoselvitys. - Luontotieto Keiron Oy, Helsinki.

*Luontotieto Keiron Oy 2007: Espoon Pellaksenmäen asemakaavahanke. Luontoselvitys. 2007. — Luontotieto Keiron Oy, Helsinki. [http://www.proespoonjoki.fi/ pellas_luontoselvitys_2007.pdf].

*Luontotieto Keiron Oy 2009: Espoonkartanon selvitysalue, Finnsinmäki, Espoonkartanonmäki, Mynttilä. Luontoselvitys 2009. - Luontotieto Keiron Oy, Helsinki. [https:// docplayer.fi/24688648-Espoonkartanon-selvitysalue. html].

*Luontotieto Keiron Oy 2011: Pakankylän asemakaavan muutos. Luontoselvitys 2011. - Luontotieto Keiron Oy, Helsinki. [https://docplayer.fi/18865082-Pakankylan-asemakaavan-muutos.html].

*Luontotieto Keiron Oy 2012: Espoon kaupunki. Saariston osayleiskaava. Luontoselvitys 2011. — Espoon kaupunkisuunnittelukeskuksen julkaisuja 4. 
*Luontotieto Keiron Oy 2013: Tuusulan kunta Kellokoski. Keskustan asemakaavoitus. Luontoselvitys 2013. Luontotieto Keiron Oy, Helsinki. [https://docplayer. fi/10383657-Liite-2-tuusulan-kunta-kellokoski-keskustan-asemakaavoitus-luontoselvitys-2013.html].

*Lustila, T., Nyman, J. \& Toivio, A. 2009: Vaasan Kuninkaankartanon lepakkoselvitys 2009. — Vaasan kaupunkisuunnittelu.

*Lustila, T., Nyman, J. \& Toivio, A. 2009: Vaasan Suvilahden liikekeskuksen lepakkokartoitus 2009. — Vaasan kaupunkisuunnittelu.

Malin, J. 2002: Lepakoiden maailma on vielä tutkimaton. Maatalousnormaalikoulun alue uhanalaisen ripsisiipan tyypillistä elinympäristöä. - Keski-Uusimaa 19.9.2002.

Malmberg, A. J. 1872: Fauna Fennica. Suomen eläimistö, Nuorisolle. I-IV. Nisäkkäät, Linnut, Matelijat ja Sammakot. - Helsingissä, G.W. Edlund'in kustannuksella.

Markovets, M. J., Zelenova, N. P. \& Shapoval, A. P. 2004: Beringung von Fledermausen in der Biologischen Station Rybachy, 1957-2001. - Nyctalus (N.F.) 9: 259-268.

Masing, M. 2015: Bats of Estonia and adjacent regions. Sicista Development Centre, Haapsalu \& Tartu.

*Matikainen, J. \& Matikainen, T. 2012: Isokyrön OrismalaValtaalan osayleiskaavan luontoselvityksen päivitys sekä lepakkoselvitys 2009-2011. - Suomen Luontotieto Oy. [https://docplayer.fi/16606071-Suomen-luontotieto-oy-isokyron-orismala-valtaalan-osayleiskaavan-luontoselvityksen-paivitys-seka-lepakkoselvitys-2009-2011. html].

*Matikainen, J. \& Matikainen, T. 2012: Kemiönsaaren Gräsbölen tuulipuistohankkeen ympäristöselvitykset. Lepakkoselvitys 2011. — Suomen Luontotieto Oy. [https:// docplayer.fi/289867-Suomen-luontotieto-oy-kemionsaaren-grasbolen-tuulipuistohankkeen-ymparistoselvitykset-lepakkoselvitys-2011.html].

*Matikainen, J. \& Matikainen, T. 2012: Kemiönsaaren Nordanå-Lövbölen \& Gräsbölen tuulipuistojen ympäristöselvitykset. Lepakkoselvitys 2011. — Suomen Luontotieto Oy 6/2012. [https://docplayer.fi/289867-Suomen-luontotieto-oy-kemionsaaren-grasbolen-tuulipuistohankkeen-ymparistoselvitykset-lepakkoselvitys-2011.html].

Mela, A. J. [formerly Malmberg] 1882: Suomen luurankoiset, eli Luonnontieteellisen Suomen luurankois-eläimistö. Vertebrata Fennica. - Helsingissä, K.E. Holm'in kustannuksella.

*Mela, A. J. \& Kivirikko, K. E. 1909: Suomen luurankoiset. Vertebrata Fennica, 2nd ed. - WSOY, Porvoo.

*Metsänen, T. 2008: Kärkölän Anttilan tilan lepakkoselvitys 2008, esiselvitys. — Luontoselvitys Metsänen, Lahti.

*Metsänen, T. 2009: Lepakoiden talvi-inventointi-Apajalahdenvuoren louhos, Heinola. — Luontoselvitys Metsänen, Lahti. [https://www.heinola.fi/library/files/5c65515f566ff8a66c000153/liite7_Lepakoiden_talvi_inventointi_Apajalahdenvuoren_louhos_2009.pdf].

*Metsänen, T. 2012: Pyhtään tuulivoimayleiskaava-alueen lepakkopotentiaalin arviointi 2012. - Luontoselvitys Kotkansiipi. Luontoselvitys Metsänen. [https://projektit. fcg.fi/document/20/2146/d095255d76e26a2cd2407ec5a7636d7e/Pyhtaan_tuulivoimayleiskaava_alueen lepakkopotentiaalin_arviointi_2012.pdf].
Michaelsen, T. C., Olsen, O. \& Grimstad, K. J. 2013: Roosts used by bats in late autumn and winter at northern latitudes in Norway. - Folia Zoologica 62: 297-303.

Mitchell-Jones, A. J., Amori, G., Bogdanowicz, W., Kryštufek, B., Reijnders, P. J. H., Spitzenberger, F., Stubbe, M., Thissen, J. B. M., Vohralík, V. \& Zima, J. (eds.) 1999: The atlas of Europaean mammals. — T \& AD Poyser Ltd./Academic Press, London.

Murphy, S.E., Greenaway, F. \& Hill, D.A. 2012: Patterns of habitat use by female brown long-eared bats presage negative impacts of woodland conservation management. - Journal of Zoology 288: 177-183.

*Mäkelä, T. \& Rinne, S. 2014: Sastamalan Kortekallion tuulivoimaosayleiskaavan luontoselvitys. - FCG Suunnittelu \& Tekniikka Oy, Helsinki. [https://docplayer. fi/2613576-Sastamalan-kaupunki-sastamalan-kortekallion-tuulivoimaosayleiskaavan-luontoselvitys-raportti. html].

*Niemi, M., Erkinaro, M., Ekroos, J., Nupponen, K., Saarikivi, J. \& Nieminen, M. 2011: Hangon kantakaupungin yleiskaavaluonnoksen alueella sijaitsevat ekologiset käytävät sekä lepakkoselvitys. - Faunatica Oy, Espoo. [https://www.hanko.fi/files/2216/raportti_kaytavatarkastelu_lepakkoselvitys_2010_2.pdf].

*Nieminen, J. (ed.) 2009: Santahamina. Sotilassaaren luontoaarteet. - Edita Prima Oy, Helsinki.

*Nieminen, M. Erkinaro, M., Kuusela, T., Makkonen, H. \& Vaskelainen, E. 2008: Kirkkonummen Gesterbyn-Sepänkylän \& Kylmälän osayleiskaava-alueiden luontoselvitykset 2008. - Faunatica Oy, Espoo.

*Nieminen, M., Ahola, A., Kinnunen, J., Koskimies, P., Korhonen, A., Pajari, T., Schrader, M. \& Vasko, V. 2012: Pohjois-Satakunnan tuulivoimapuistojen kaavoitus - luontoselvitykset vuonna 2012. — Faunatica Oy, Espoo. [https://docplayer.fi/8048953-Pohjois-satakunnan-tuulivoimapuistojen-kaavoitus-luontoselvitykset-vuonna-2012.html].

*Nieminen, M., Erkinaro, M., Makkonen, H., Niiranen, S., Nupponen, K., Schrader, M. \& Sundell, P. R. 2010: Sipoon Talman osayleiskaava-alueen luontoselvitykset vuonna 2010. - Faunatica Oy, Espoo. [https://www. sipoo.fi/easydata/customers/sipoo/files/Maankaytto_ kaavoitus/Talma_luontoselvitysraportti_2010_netti.pdf].

*Nieminen, M., Erkinaro, M., Vuorinen, I., Nordenswan, G. \& Sundell, P. 2008: Vantaan Viinikkalan luontoselvitykset vuonna 2008. - Faunatica Oy, Espoo.

*Nieminen, M., Hellstedt, P., Makkonen, H. \& Niiranen, S. 2011: Vihdin Eerolan luontoselvitykset vuonna 2011. Faunatica Oy, Espoo. [https://docplayer.fi/4383483-Vihdin-eerolan-luontoselvitykset-vuonna-2011.html].

*Nieminen, M., Nupponen, K., Kinnunen, J., Makkonen, H., Erkinaro, M., Tammelin, H. \& Sundell, P. R. 2009: Siuntion Tulotien asemakaava-alueen luontoselvitykset vuonna 2009. - Faunatica Oy, Espoo. [https://www. siuntio.fi/library/files/5b87cef5c9105853af000c97/ raportti_Siuntio_Storsvik_2009.pdf].

*Nieminen, M., Sundell, P. R., Erkinaro, M., Kunttu, P. \& Vuorinen, I. 2007: Espoon Kulloon kaava-alueen luontoselvitykset vuonna 2007 sekä arvio hankkeen vaikutuksista Matalajärven Natura-alueeseen. - Faunatica 
Oy, Espoo.

*Nieminen, M., Sundell, P. R., Erkinaro, M., Kunttu, P. \& Vuorinen, I. 2008: Espoon Kulloonmäki II:n kaava-alueen luontoselvitykset vuonna 2007 sekä arvio hankkeen vaikutuksista Matalajärven Natura-alueeseen. - Faunatica Oy, Espoo.

*Nordberg, S. 1938: Den åländska däggdjursfaunans utveckling. - Acta Societatis pro Fauna et Flora Fennica 62: $1-39$.

*Nummi, P., Kattainen, S., Ulander, P. \& Hahtola, A. 2011: Bats benefit from beavers: a facilitative link between aquatic and terrestrial food webs. - Biodiversity and Conservation 20: 851-859.

*Nupponen, K., Nieminen, M., Erkinaro, M., Makkonen, H., Niiranen, S. \& Sundell, P. R. 2010: Sipoon Eriksnäsin osayleiskaava-alueen luontoselvitykset vuonna 2010. — Faunatica Oy, Espoo. [https://www.sipoo.fi/easydata/ customers/sipoo/files/2011_keke/yleiskaavat/eriksnas/ liitteet_7-11_eriksnas.pdf].

*Nyholm, E. S. 1958: Otteita päiväkirjastani [Vertebratobservationer i sydvästra Tavastland: utdrag ur min dagbok]. - Luonais-Hämeen Luonto 4: 18-19. [In Finnish with Swedish summary].

*Nyholm, E. S. 1959: Lepakoiden päiväpiiloista. — Suomen Luonto 18: 49-56.

*Nyholm, E. S. 1965: Zur Ökologie von Myotis mystacinus (Leisl.) und M. daubentoni (Leisl.) (Chiroptera). Annales Zoologici Fennici 2: 77-123.

*Nyholm, E. S. 1955: Ensimmäiset talvehtivat siipat Suomessa. - Luonnon Tutkija 59: 116-17.

*Nyholm, E. S. 1955: Nisäkäshavaintoja Rautalammilta v. 1954 (PH). — Luonnon Tutkija 59: 88.

*Nyman, J. 2008: Vaasan Yttersundomin luontoselvitys 2008. — Vaasan kaupunkisuunnittelu.

*Oja, J. \& Oja, S. 2007: Isokylän-Toijalan osayleiskaavan luontoselvitys 2007. - Suomen Luontotieto Oy.

*Oja, J. \& Oja, S. 2009: Eurajoen keskustan ja Lapijoen osayleiskaava-alueen luontoarvojen perusselvitys. - Suomen Luontotieto Oy. [https://docplayer. fi/40550732-Suomen-luontotieto-oy-eurajoen-keskustan-ja-lapijoen-osayleiskaavaalueen-perusselvitys-suomen-luontotieto-oy-25-2009-jyrki-oja-satu-oja.html].

*Onttonen, N. 2013: Kinkkulanmäen kasvillisuus- ja lepakkoselvitys. — Ramboll Oy, Lahti. [http://www.hartola.fi/ liitteet/Asuminen_ja_ymparisto/rakennusliitteet/kinkkulanmaenlepakkoselvitys.pdf].

*Parkko, P. 2010: Karhulan Hovin ja Pylvässalin asemakaavan luontoselvitys 2010. - Luontoselvitys Kotkansiipi, Kotka.

*Parkko, P. 2010: Kotkan Munsaaren-Sikosaaren asemakaavan luontoselvitys 2010. - Luontoselvitys Kotkansiipi, Kotka.

*Parkko, P. 2011: Kotkan Puistotien asemakaavoitukseen liittyvä luontoselvitys 2011. — Luontoselvitys Kotkansiipi, Kotka.

*Parkko, P. 2011: Pyhtään Munapirtin luontomatkailuun liittyvä luontoselvitys 2011. — Luontoselvitys Kotkansiipi, Kotka.

*Parkko, P. 2012: Haminan Alhonmäen louhintasuunnitelmaan liittyvä luontoselvitys 2012. — Luontoselvitys
Kotkansiipi, Kotka.

Paunović, M. \& Juste, J. 2016: Pipistrellus nathusii. — The IUCN Red List of Threatened Species. [http://dx.doi.org/ 10.2305/IUCN.UK.2016-2.RLTS.T17316A22132621.en].

Pētersons, G. 2004: Seasonal migrations of north-eastern populations of Nathusius' bat Pipistrellus nathusii. Myotis 41-42: 29-56.

Pētersons, G. 2014: Agreement on the conservation of bats in Europe - Report on the implementation of the agreement in Latvia 2010-2014. - Inf.EUROBATS.MoP7.24, http://www.eurobats.org/sites/default/files/documents/ pdf/National_Reports/Inf.MoP7_.24-National\%20Implementation $\% 20$ Report $\% 20$ of $\% 20$ Latvia.pdf.

Piraccini, R. 2016: Myotis dasycneme. — The IUCN Red List of Threatened Species. [http://dx.doi.org/10.2305/ IUCN.UK.2016-2.RLTS.T14127A22055164.en].

*Pöyry Environment Oy 2006: Talvivaara Projekti Oy. Luontoselvitysten täydentäminen v. 2006. — Pöyry Environment Oy, Oulu.

*Pöyry Management Consulting Oy 2012: Kalajoen Tohkojan tuulipuiston ympäristövaikutusten arviointiselostus (YVA-selostus). - Pöyry Management Consulting Oy. [https://www.ymparisto.fi/fi-FI/Asiointi_luvat_ja_ymparistovaikutusten_arviointi/Ymparistovaikutusten_arviointi/YVAhankkeet/Tohkojan_tuulipuistohanke_Kalajoki].

*Pöyry Oy 2013: Lappeenrannan kaupunki. Korvenkylän osayleiskaava. Luontoselvitys. - Pöyry Finland Oy, Turku. [https://www.lappeenranta.fi/loader.aspx?id=2e82ffcd3a42-45af-9b6a-7da547893605].

Radloff, F. W. 1795: Beskrifning öfver Aland. - J. C. Frenckells Boktryckeri, Åbo.

*Rahinantti, M. 2014: Uuraisten kunta, osayleiskaava-alue. Selvitys lepakoiden levähdys- ja lisääntymispaikoista. - Uuraisten kunta. [https://docplayer.fi/12791557-Uuraisten-kunta-osayleiskaava-alue-selvitys-lepakoiden-levahdys-ja-lisaantymspaikoista.html].

*Rintamäki, P. 2010: Lempäälän keskusta-alueen lepakkoselvitys 2010. — Lempäälän kunta. [https://docplayer. fi/56562222-Lempaalan-keskusta-alueen-lepakkoselvitys-2010.html].

*Routasuo, P. 2009: Espoon Niipperinniityn kaava-alueen luontoselvitys 2009. - Ympäristösuunnittelu Enviro Oy, Mikkeli.

Rydell, J. 1989: Occurrence of bats in northernmost Sweden $\left(65^{\circ} \mathrm{N}\right)$ and their feeding ecology in summer. - Journal of Zoology 227: 517-529.

Rydell, J., Bach, L., Bach, P., Guia Diaz, L., Furmankiewicz, J. Hagner-Wahlsten, N., Kyheröinen, E.-M., Lilley, T., Masing, M., Meyer, M. M., Petersons, G., Šuba, J., Vasko, V., Vintulis, V. \& Hedenström, A. 2014: Phenology of migratory bat activity across the Baltic Sea and the south-eastern North Sea. - Acta Chiropterologica 16: $139-147$.

Sallamaa, S., Kyheröinen, E.-M. \& Hanski, I. K. 2011: Roost selection and site fidelity of bats using bat boxes. - In: Hutson, A. M. \& Lina, P. H. C. (eds.), 12th European Bat Research Symposium - Programme, Abstracts, List of Participants: 85-86. Gamtos tyrimų centras, Vilnius.

*Salovaara, K. 2001: Vaivaislepakko havaittu ensi kerran 
Suomessa. - Luonnon Tutkija 105: 130.

*Salovaara, K. 2007: Kääpiölepakko - uusi lepakkolaji Suomessa. - Luonnon Tutkija 111: 100.

Siivonen, L. (ed.) 1956: Suuri nisäkäskirja. — Otava, Helsinki.

*Siivonen, L. (ed.) 1972: Suomen nisäkkäät 1. — Kustannusosakeyhtiö Otava, Keuruu.

Siivonen, L. 1967: Pohjolan nisäkkäät. — Otava, Helsinki.

Siivonen, L. 1968: Nordeuropas däggdjur. - P.A. Norstedt \& söners förlag, Stockholm.

*Siivonen, Y. 2002: Espoon eteläosien lepakkokartoitus 2002. - Espoon ympäristölautakunnan julkaisu 3/2002.

*Siivonen, Y. 2002: Järvenpään kaupungin lepakkokartoitus 2001-2002. - Ympäristötutkimus Oy Metsätähti.

*Siivonen, Y. 2002: Tampereen kantakaupungin lepakkokartoitus 2002. - Bat Group Finland ry., Tampereen kaupunki, ympäristövalvonta.

*Siivonen, Y. 2002: Vantaan lepakkokartoitus 2001-2002. Vantaan kaupunki.

*Siivonen, Y. 2003: Raision kaupungin lepakkokartoitus 2003. - Raision kaupunki.

*Siivonen, Y. 2004: Helsingin lepakkolajisto ja tärkeät lepakkoalueet vuonna 2003. - Helsingin kaupungin ympäristökeskuksen julkaisuja 3/2004.

*Siivonen, Y. 2004: Ikaalisten kaupungin lepakkokartoitus 2004. - Batcon Group, Espoo.

*Siivonen, Y. 2004: Nurmijärven lepakkokartoitus 2004. Batcon Group, Espoo. [https://www.nurmijarvi.fi/wp-content/uploads/2019/09/Lepakkokartoitus_2004.pdf].

*Siivonen, Y. 2005: Helsingin Seurasaaren lepakot 2000 2005. Kehittämis- ja hoitosuunnitelmaluonnoksen vaikutustenarviointi. - Batcon Group, Espoo.

*Siivonen, Y. 2005: Loviisan lepakkokartoitus 2005. Batcon Group, Espoo.

*Siivonen, Y. 2005: Tampereen Särkijärven sillan lähiympäristön merkittävimmät lepakkoalueet kesällä 2005. - Batcon Group, Espoo. [https://docplayer. fi/11073557-Tampereen-sarkijarven-sillan-lahiympariston-merkittavimmat-lepakkoalueet-kesalla-2005-kartoitusraportti.html].

*Siivonen, Y. 2007: Hyvinkään Ohkolan (Kaukasten) louhoshankkeen lähiympäristön lepakot. — Hyvinkään kaupunki, Uudenmaan ympäristökeskus.

*Siivonen, Y. \& Wermundsen, T. 2003a: Distribution of Nathusius' pipistrelle Pipistrellus nathusii (Keyserling \& Blasius, 1839) in Finland. - Studia Chiropterologica 3-4: 43-47.

*Siivonen, Y. \& Wermundsen, T. 2003b: First records of Myotis dasycneme and Pipistrellus pipistrellus in Finland. - Vespertilio 7: 177-179.

*Siivonen, Y. \& Wermundsen, T. 2006: Haminan kantakaupungin, Vilniemen \& Summanjokilaakson lepakkokartoitus 2005-2006. - Wermundsen Consulting Oy, Espoo.

*Siivonen, Y. \& Wermundsen, T. 2006: Huppionmäen asemakaava-alueen lepakkokartoitus. - Wermundsen Consulting Oy/Batcon Group, Espoo. [https://www.tampere. fi/ytoteto/aka/nahtavillaolevat/8255/selvitykset/lepakkoselvitys.pdf].

*Siivonen, Y. \& Wermundsen, T. 2006: Kaukajärvi, Ruskontie kaakko asemakaava-alueen lepakkokartoitus
2006. - Wermundsen Consulting Oy/Batcon Group, Espoo. [https://www.tampere.fi/ytoteto/aka/nahtavillaolevat/8057/8057liite2.pdf].

*Siivonen, Y. \& Wermundsen, T. 2006: Lahdesjärvi-Lakalaiva osayleiskaava-alueen lepakkokartoitus 2006. - Wermundsen Consulting Oy/Batcon Group, Espoo. [https://www.tampere.fi/liitteet/5obZQt9zj/lepakkokartoitus.pdf].

*Siivonen, Y. \& Wermundsen, T. 2006: Nurmi-Sorilan osayleiskaava-alueen lepakkokartoitus 2005-2006. - Wermundsen Consulting Oy/Batcon Group, Espoo. [https://www.tampere.fi/liitteet/5pofntzTP/lepakkokartoitus1.pdf].

*Siivonen, Y. \& Wermundsen, T. 2006: Rahola, Tykkitienkatu asemakaava-alueen lepakkokartoitus 2006. - Wermundsen Consulting Oy/Batcon Group, Espoo. [https:// docplayer.fi/24678901-Rahola-tykkitienkatu-asemakaava-alueen-lepakkokartoitus-2006.html].

*Siivonen, Y. \& Wermundsen, T. 2006: Sipoon lepakkokartoitus 2006. - Wermundsen Consulting Oy/Batcon Group, Espoo. [https://www.sipoo.fi/easydata/customers/sipoo/files/2011_keke/yleiskaavat/pohjoispaippinen/sipoon_lepakkokartoitus_2006.pdf].

*Siivonen, Y. \& Wermundsen, T. 2006: Tampereen Niemenrannan lepakkoselvitys 2006. - Wermundsen Consulting Oy/Batcon Group, Espoo. [https://docplayer. fi/60082806-Tampereen-niemenrannan-lepakkoselvitys-2006.html].

*Siivonen, Y. \& Wermundsen, T. 2006: Tarastenjärven osayleiskaava-alueen lepakkokartoitus 2006. - Wermundsen Consulting Oy, Espoo. [https://www.tampere. fi/liitteet/t/5m4ETdPNW/tarastenjarvioyklepakkoselvitys.pdf].

*Siivonen, Y. \& Wermundsen, T. 2006: Vantaan Itä-Hakkilan lepakkoselvitys 2006. - Wermundsen Consulting Oy, Espoo. [https://www.vantaa.fi/instancedata/prime_ product_julkaisu/vantaa/embeds/vantaawwwstructure/119027_Vantaan_Ita-Hakkilan_lepakkoselvitys_2006.pdf].

*Siivonen, Y. \& Wermundsen, T. 2006: Vuoreksen osayleiskaava-alueen lepakkokartoitus 2006. — Wermundsen Consulting Oy/Batcon Group, Espoo. [https://www. tampere.fi/ytoteto/aka/nahtavillaolevat/8263/selvitykset/ lepakkoselvitys.pdf].

*Siivonen, Y. \& Wermundsen, T. 2006: Ylöjärven lepakkokartoitus 2006. - Wermundsen Consulting Oy, Espoo. [http://www2.ylojarvi.fi/Dynasty/kokous/20184762-319.pdf].

*Siivonen, Y. \& Wermundsen, T. 2007: Lentävänniemen lepakkokartoitus 2007. - Wermundsen Consulting Oy, Espoo. [https://www.tampere.fi/ytoteto/aka/nahtavillaolevat/8354/selvitykset/lentavanniemi_lepakkokartoitus_2007.pdf].

*Siivonen, Y. \& Wermundsen, T. 2007: Riihimäen lepakkokartoitus 2007. — Riihimäen kaupungin ympäristönsuojeluyksikkö ja kaavoituspalvelut. [https://www. riihimaki.fi/wp-content/uploads/sites/3/2015/01/Riihim\%C3\%A4en-lepakkokartoitus-2007.pdf].

*Siivonen, Y. \& Wermundsen, T. 2007: Vantaan Hakunilan-Ojangon alueen lepakkoselvitys 2007. — Wer- 
mundsen Consulting Oy, Espoo. [https://www.vantaa. fi/instancedata/prime_product_julkaisu/vantaa/embeds/ vantaawwwstructure/119026 Vantaan Hakunilan-Ojangon_lepakkoselvitys_2007.pdf].

Siivonen, Y. \& Wermundsen, T. 2008a: Characteristics of winter roosts of bat species in southern Finland. Mammalia 72: 50-56.

*Siivonen, Y. \& Wermundsen, T. 2008b: Distribution and foraging habitats of bats in northern Finland: Myotis daubentonii occurs north of the Arctic Circle. - Vespertilio 12: 41-48.

*Siivonen, Y. \& Wermundsen, T. 2008c: Distribution of Natterer's bat (Myotis nattereri) in Finland. - Nyctalus 13(1): 42-47.

*Siivonen, Y. \& Wermundsen, T. 2008: Lopen kirkonkylän, Launosten, Kormun ja Läyliäisten lepakkokartoitus 2008. - Wermundsen Consulting Oy, Espoo. [https:// loppi.fi/wp-content/uploads/sites/9/2015/06/Lopen-lepakkokartoitus.pdf].

*Siivonen, Y. \& Wermundsen, T. 2008: Pispalan lepakkokartoitus 2008. - Wermundsen Consulting Oy, Espoo. [https://www.tampere.fi/ytoteto/aka/nahtavillaolevat/8257/selvitykset/8257_lepakkokartoitus_2008.pdf].

*Siivonen, Y. \& Wermundsen, T. 2008: Viljakkalan lepakkokartoitus 2008. - Wermundsen Consulting Oy, Espoo.

*Siivonen, Y. \& Wermundsen, T. 2008: Yhteenveto Tampereen Virolaisen lepakkotilanteesta 2002-2008. - Wermundsen Consulting Oy, Espoo.

*Sipari, J. 2012: Parikkala. Keskustaajaman asemakaavan päivitys. Ympäristöarviointi. - Parikkalan kunta. [https://docplayer.fi/31233217-Keskustaajaman-asemakaavan-paivitys.html].

*Skarén, U. 1992: Isoviiksisiippa — vähän tunnettu lepakkomme. - Luonnon Tutkija 96: 4-11.

Skiba, R. 2003: Europäische Fledermäuse. - Die Neue Brehm-Bücherei Bd. 648, Westarp Wissenschaften-Verlaggesellschaft mbH, Hohenwarsleben.

Sluiter, J. W., van Heerdt, P. F. \& Voute, A. 1971: Contribution to the population biology of the pond bat, Myotis dasycneme (Boie, 1825). - Decheniana Beiheft 18: 1-44.

*Snellman, P. 2006: Lintubongari kuvasi uuden nisäkäslajin. - Iltasanomat 1.8.2006.

*Soini, P., Helminen, S.-L., Hagner-Wahlsten, N., Yrjölä, R., Friman, M., Santaharju, J. \& Vickholm, J. 2008: Lahnuksen alueen luontoselvitykset 2007. - Espoon ympäristölautakunnan julkaisusarja 1/2008.

*Stjernberg, T. 1996: Fransfladdermusen i östra Fennoskandien. - In: Gärdenfors, U. \& Carlson, A. (eds.), Med huvudet före. Fetskrift till Ingemar Ahléns 60-årsdag. Sveriges Lantbruksuniversitetet, Institutionen för viltekologi. Rapport 33: 56-62.

Stjernberg, T. 1998: Myotis natteri. In: Kotiranta, H., Uotila, P., Sulkava, S. \& Peltonen, S.-L. (eds.), Red data book of East Fennoscandia: 185-186. Ministry of the Environment, Finnish Environment Institute, Botanical Museum, Finnish Museum of Natural History, Helsinki

Stjernberg, T., Haukkovaara, O. \& Lokki, J. 1993: The status and distribution of bats in Finland. - In: Palmeirim, J. M., Rodrigues, L. \& Rabaca, J. (eds.), VI European Bat Research Symposium, Evora, Portugal, 22-27 August
1993. Programme, Abstracts, List of Participants: 47. European Bat Research Organization, Evora, Portugal, University of Evora.

Stubbe, M., Ariunbold, J., Buuveibaatar, V., Dorjderem, S., Monkhzul, Ts., Otgonbaatar, M., Tsogbadrakh, M., Hutson, A.M., Spitzenberger, F., Aulagnier, S., Juste, J., Coroiu, I., Paunovic, M. \& Karataş, A. 2008: Myotis daubentonii. - The IUCN Red List of Threatened Species. [http://dx.doi.org/10.2305/IUCN.UK.2008.RLTS. T14128A4400742.en].

Størkersen, Ø, Syvertsen, P.O., Isaksen, K. \& Michaelsen, T.C. 2014: The Agreement on the Conservation of Populations of European Bats - National report 2014 on the implementation of the agreement in Norway. Inf.EUROBATS.MoP7.33, http://www.eurobats.org/ sites/default/files/documents/pdf/National_Reports/Inf. MoP7_.33-National\%20Implemenatation\%20Report $\% 20$ of $\% 20$ Norway.pdf.

*Suoknuuti, M. \& Parkko, P. 2011: Kotkan Hallan tuulivoimasuunnitteluun liittyvät luontoselvitykset 2011. Lepakko-, linnusto- ja kasvillisuusselvitys. - Luontoselvitys Kotkansiipi, Kotka. [https://www.ymparisto. fi/download/noname/\%7BB0667534-16F5-4FAC-BE8 4-F51FDADA766D\%7D/76504

*Suomalainen, E. W. 1920: Muutamia havaintoja lepakoiden piilopaikoista. - Luonnon Ystävä 24: 66-67.

*Suomalainen, E. W. 1920: Vieläkin lepakoiden päivänaikaisista piilopaikoista. - Luonnon Ystävä 24: 92-93.

*Suorsa, V. 2013: Tervolan Löylyvaaran ja Varevaaran tuulivoimahankkeet. Lepakkoselvitys. - FCG Suunnittelu ja Tekniikka Oy, Helsinki. [https://docplayer. fi/36677978-Tervolan-loylyvaaran-ja-varevaaran-tuulivoimahankkeet.html].

*Tammelin, H. 2011: Majvikin ja Granön lepakot vuonna 2011. — T:mi Ekologinen ympäristökartoitus, Karkkila. [https://www.sipoo.fi/easydata/customers/sipoo/ files/2011_keke/yleiskaavat/ostersundom/luontoselvitys/ liite_lepakot_teksti.pdf].

*Toivio, A. 2009: Vaasan Sundomin maantäyttöalueen luontoselvitys 2009. - Vaasan kaupunkisuunnittelu.

*Tuominen, H. \& Ahlman, S. 2012: Porin Jakkuvärkin tuulivoimapuiston lepakoiden kevätmuutto- ja pesimäselvitys 2012. - Ahlman Konsultointi \& suunnittelu. [https://docplayer.fi/67849554-Porin-jakkuvarkin-tuulivoimapuiston-lepakoiden-kevatmuutto-ja-pesimaselvitys-2012-ahlman.html].

*Tuomisto, H. 2009: Kertunlaakson luontoselvitys 2009. Seinäjoen kaupunki.

*Tuomisto, H. 2009: Lepakkoselvitys. Roveksen osayleiskaava 2025. - Seinäjoen kaupunki. Seinäjoki. [http:// www.seinajoki.fi/material/attachments/seinajokifi/ asuminenjaymparisto/kaavoitus/asemakaavat/55roves/ vfY6hfeWL/Lepakkoselvitys_Roves_oyk_2009.pdf].

*Tuomisto, H. 2010: Luontoselvitys Tanelinranta, Keski-Nurmo, Veneskoski. — Seinäjoen kaupunki. [https:// www.seinajoki.fi/material/attachments/seinajokifi/asuminenjaymparisto/kaavoitus/yleiskaavat/keski-nurmonveneskoskenjakouranosayleiskaavat/6CsQ9Y6qU/36273. pdf].

*Tuomisto, H. 2011: Luontoselvitys Viitalankylä-Koura. 
— Seinäjoen kaupunki. [https://docplayer.fi/49718344Luontoselvitys-viitalankyla-koura.html].

*Turkulainen, S. \& Yli-Tuomi, I. 2012: Lappeenrannan kaupunki, Tiuruniemen ydinalueen ja Caprin asemakaava. Luontoselvitys. - Pöyry Finland Oy, Turku.

*Tverin, M., Karlsson, R. \& Hagner-Wahlsten, N. 2010: Inventering av fladdermöss inom Kastelholms planeområde, Sund 2010. — BatHouse, Kauniainen. [http:// old.regeringen.ax/.composer/upload/socialomiljo/ SLUTRAPPORTSundfladdermoss2010.pdf].

Tõrv, T. 2014: Agreement on the conservation of populations of European bats - national implementation report of Estonia. - Available at http://www.eurobats. org/sites/default/files/documents/pdf/National_Reports/ national\%20report_estonia\%202014.pdf.

Ulvinen, T. 1980: Pohjois-Pohjanmaan ja Kemin Lapin eliömakuntien jakaminen [Division of the Finnish biological provinces Pohjois-Pohjanmaa (Ostrobotnia borealis) and Kemin Lappi (Lapponia kemensis)]. - Luonnon Tutkija 84: 176-179. [In Finnish with English summary].

*Urho, K. 2014: Keski-Pohjanmaan litiumprovinssin lepakkoselvitys. — Ramboll, Lahti. [https://www.keliber.fi/ site/assets/files/1278/keliber-oy-keski-pohjanmaan-litiumprovinssin-lepakkoselvitys.pdf].

*Urho, K. 2014: Pesolan ja Korkeamaan tuulivoimapuistojen lepakkoselvitys. — Ramboll, Lahti. [https://docplayer. fi/67693883-Pesolan-ja-korkeamaan-tuulivoi-mapuistojen-lepakkoselvitys-suomen-hyotytuuli-oy-saba-tuuli-oy-ab-suomen-hyotytuuli-oy-saba-tuuli-oy-ab.html].

*Vahekoski, M. 2010: Koskenkorvan linnusto-, viitasammakko-ja lepakkoselvitys. Ilmajoen kaupunki. — Luontopalvelu Kraakku, Säkylä. [http://www.ilmajoki.fi/files/ Kaava-asiat/Koskenkorvan_linnusto_viitasammakko_ ja_lepakkoselvitys.pdf].

*Vahekoski, M. 2010: Neitsytmäki. Euran kunta. Luontopalvelu Kraakku, Säkylä. [https://docplayer. fi/2613175-Neitsytmaki-euran-kunta-13-9-2010-luontopalvelu-kraakku-marika-vahekoski.html].

*Vasko, V. \& Hagner-Wahlsten, N. 2008: Rauman sataman laajennusalueen lepakkoselvitys 2008. - BatHouse, Kauniainen \& Ympäristösuunnittelu Enviro Oy, Mikkeli.

*Vasko, V. \& Hagner-Wahlsten, N. 2010: Bergön tuulivoimapuiston lepakkoselvitys 2010. - BatHouse, Kauniainen. [https://docplayer.fi/3833198-Bergon-tuulivoimapuiston-lepakkoselvitys-2010.html].

*Vasko, V. \& Hagner-Wahlsten, N. 2012: Luvian Lemlahden tuulivoimapuiston lepakkoselvitys 2011. - BatHouse, Kauniainen.

*Vauhkonen, M. 2005: Espoon Träskändan luontoselvitykset 2005. - Espoon ympäristölautakunnan julkaisusarja $2 / 2005$.

*Vauhkonen, M. 2009: Heinolan Tähtiniemen lepakkoselvitys. - Ympäristösuunnittelu Enviro Oy, Mikkeli.

*Vauhkonen, M. 2011: Mikkelin Salosaaren länsiosan luontoselvitys 2011. - Ympäristösuunnittelu Enviro Oy, Mikkeli.

*Vauhkonen, M. \& Nironen, M. 2011: Mikkelin Rokkalan alueen luontoselvitys 2010-2011. - Ympäristösuunnittelu Enviro Oy, Mikkeli.

Vesterinen, E. 2015: Food webs in the era of molecular revo- lution - like resolving the Gordian knot with a tricorder. - Annales Universitatis Turkuensis A II 307: 1-46.

*Vihervaara, P. 2003: Kaarinan Ala-Lemun ja Voivalan kaavoitusalueiden lepakkokartoitus 2003. - Kaarinan kaupunki. [https://www.kaarina.fi/ymparisto_ja_luonto/ ymparistovalvonta/luonnonsuojelu/fi_FI/lajiensuojelu/_ files/75634303101763825/default/ala_lemu_voivala lepakkokart2003.doc

*Vihervaara, P. 2004: Lepakoiden (Chiroptera: Vespertilionidae) alueelliseen ja ajalliseen vaihteluun vaikuttavat tekijät Saaristomerellä ja Varsinais-Suomessa sekä niiden huomioon ottaminen luonnonsuojelussa. - M.Sc. thesis, Turun yliopisto.

*Vihervaara, P. 2004: Turun ja Kaarinan Natura 2000 -alueiden lepakkokartoitus 2003. - Julkaisuja 1/2004, Turun kaupunki, Ympäristönsuojelutoimisto.

*Vihervaara, P. 2006: Kolvananuuro ja lähialueet, Natura 2000 -alueiden lepakkoinventointi 2006. — Biologitoimisto Vihervaara, Kuopio.

*Vihervaara, P. 2006: Linnansaaren kansallispuiston lepakkoinventointi 2005. - BIRD, Metsähallitus, Savonlinna.

*Vihervaara, P. 2007: Kaarinan läntisen ohikulkutien lepakkokartoitus 2007. — Biologitoimisto Vihervaara, Kuopio.

*Vihervaara, P. 2007: UPM-Kymmene Oyj:n Harvialan metsätilojen lepakkokartoitus 2007. — Biologitoimisto Vihervaara, Kuopio.

*Vihervaara, P. 2009: Neulamäen asevarikon lepakkokartoitus. - Biologitoimisto Vihervaara, Kuopio.

*Vihervaara, P., Vehviläinen, H., Karhilahti, A. \& Lappalainen, M. 2003: Talvehtiva ripsisiippa Turussa. - Luonnon Tutkija 107: 19-20.

*Vihervaara, P. \& Virtanen, T. 2006: Puijon ja Karhonsaaren lepakkokartoitus. - Biologitoimisto Vihervaara, Kuopio.

*Vihervaara, P., Virtanen, T. \& Välimaa, I. 2008: Lepakot ja metsätalous - isoviiksisiippojen radioseurantatutkimus UPM-Kymmenen Oyj:n Janakkalan Harvialan metsätiloilla 2008. - Biologitoimisto Vihervaara Oy, Kuopio.

Viitanen, P. 1967: Hibernation and seasonal movements of the viper, Vipera berus (L.), in southern Finland. Annales Zoologici Fennici 4: 472-546.

*Virtanen, T. 2009: Tampereen kaupungin lepakkoselvitys 2009: Ranta-Tampella. — Biologitoimisto Vihervaara Oy, Tampere. [https://www.tampere.fi/ytoteto/aka/nahtavillaolevat/8333/selvitykset/liite09_lepakkokartoitus_090831.pdf].

*Virtanen, T. 2011: Ilmajoki-Kurikan tuulipuistoalueen lepakkokartoitus 2011. - Biologitoimisto Vihervaara Oy, Kuopio. [https://docplayer.fi/12791076-Ilmajoki-kurikan-tuulipuistoalueen-lepakkokartoitus-2011.html].

*Virtanen, T. 2011: Savonrannan tuulipuistoalueen lepakkokartoitus 2011. - Biologitoimisto Vihervaara Oy, Kuopio. [http://www.savonlinna.fi/filebank/4949-Liite_5_ Lepakkoselvitys.pdf].

*Virtanen, T. 2011: Vähäkyrön tuulipuistoalueiden lepakkokartoitus 2011. - Biologitoimisto Vihervaara Oy, Kuopio.

*Virtanen, T. \& Vihervaara, P. 2007: Herrainsuon lepakkoselvitys 2007. Tampereen kaupungin asemakaava 
no 7957. - Biologitoimisto Vihervaara Oy, Kuopio. [https://docplayer.fi/127297297-Herrainsuon-lepakkoselvitys-2007-tampereen-kaupungin-asemakaava-no-7957.html].

*Virtanen, T. \& Vihervaara, P. 2007: Tampereen kaupungin lepakkoselvitys 2007: Hirviniemi. - Biologitoimisto Vihervaara Oy, Kuopio.

*Virtanen, T. \& Vihervaara, P. 2007: Tampereen kaupungin lepakkoselvitys 2007: Iidesjärvi. — Biologitoimisto Vihervaara Oy, Kuopio.

*Virtanen, T. \& Vihervaara, P. 2007: Tampereen kaupungin lepakkoselvitys 2007: Kauppi, Medi-Park 3. - Biologitoimisto Vihervaara Oy, Kuopio.

*Virtanen, T. \& Vihervaara, P. 2007: Tampereen kaupungin lepakkoselvitys 2007: Linnainmaa, Kauppila. — Biologitoimisto Vihervaara Oy, Kuopio.

*Virtanen, T. \& Vihervaara, P. 2007: Tampereen kaupungin lepakkoselvitys 2007: Mattilanmäki. - Biologitoimisto Vihervaara Oy, Kuopio. [https://docplayer. fi/62598044-Tampereen-kaupungin-lepakkoselvitys-2007-mattilanmaki.html].

*Virtanen, T. \& Vihervaara, P. 2007: Tampereen kaupungin lepakkoselvitys 2007: Ojala. — Biologitoimisto Vihervaara Oy, Kuopio.

*Virtanen, T. \& Vihervaara, P. 2007: Tampereen kaupungin lepakkoselvitys 2007: Sisaruspohja. — Biologitoimisto Vihervaara Oy, Kuopio. [https://www.tampere.fi/liitteet/5sjyI9d01/lepakkoselvitys.pdf].

*Virtanen, T. \& Vihervaara, P. 2007: Tampereen kaupungin lepakkoselvitys 2007: Tammela. — Biologitoimisto Vihervaara Oy, Kuopio. [https://www.tampere.fi/ytoteto/ aka/nahtavillaolevat/8330/selvitykset/tammelan_lepakkoselvitys 2007.pdf].

*Virtanen, T. \& Vihervaara, P. 2008: Hirviniemen lepakkoyhdyskunnan tarkennuskartoitus 2007. — Biologitoimisto Vihervaara Oy, Kuopio.

*Virtanen, T. \& Vihervaara, P. 2008: Lamminrahkan lepakkoselvitys. - Biologitoimisto Vihervaara Oy, Kuopio. [https://docplayer.fi/12507950-Lamminrahkan-lepakkoselvitys-2008.html].

*Virtanen, T. \& Vihervaara, P. 2008: Raholan kartanon alueen lepakkoselvitys 2008. - Biologitoimisto Vihervaara Oy, Kuopio. [http://tampere.cloudnc.fi/download/ noname/\%7Bb578214e-5978-4d7c-91b4-0b802be15fe$\mathrm{d} \% 7 \mathrm{D} / 2775148$

*Virtanen, T. \& Vihervaara, P. 2009: Lahdesjärvi-Lakalaivan osayleiskaavan lepakkokartoituksen tarkennus. — Biologitoimisto Vihervaara Oy, Kuopio.

*Virtanen, T. \& Vihervaara, P. 2009: Pispalan lepakkokartoituksen tarkennus. - Biologitoimisto Vihervaara Oy, Kuopio.

*Virtanen, T. \& Vihervaara, P. 2009: Vammalan Hiedan sillan lepakkokartoitus 2009. - Biologitoimisto Vihervaara Oy, Kuopio.

*Voimavapriikki Oy 2011: Forssan, Jokioisten ja Tammelan tuulivoimahanke Kiimassuo. Ympäristövaikutusten arviointiselostus. — Voimavapriikki Oy. [https://www.
ymparisto.fi/download/noname/\%7BE3AF7F58-EBBB-4027-BE41-EA7ED4C1D9DF\%7D/59305

*Warén, E. J. 1881: Iakttagelser om däggdjur och foglar i Suonenjoki och Viitasaari samt Valkeala socknar. Meddelanden af Societas pro Fauna et Flora Fennica 7: 111-126.

Wermundsen T. 2010: Bat habitat requirements - implications for land use planning. - Dissertationes Forestales 111: 1-49. [https://doi.org/10.14214/df.111].

*Wermundsen, T. \& Mäkelä, T. 2012: Vartiosaaren lepakkoselvitys. Loppuraportti. - Helsingin kaupunkisuunnitteluvirasto, FCG Suunnittelu ja Tekniikka Oy, Helsinki. [https://www.hel.fi/hel2/ksv/liitteet/2013_kaavakuvat/1001_2_lepakkoselvitys.pdf].

*Wermundsen, T. \& Siivonen, Y. 2004: Distribution of Pipistrellus species in Finland. - Myotis 41-42: 93-98.

Wermundsen, T. \& Siivonen, Y. 2008: Foraging habitats of bats in southern Finland. - Acta Theriologica 53: 229-240.

Wermundsen, T. \& Siivonen, Y. 2010: Seasonal variation in use of winter roosts by five bat species in south-east Finland. - Central European Journal of Biology 5: 262-273.

*Ympäristökonsultointi Jynx Oy 2013: Ponsivuoren luontoselvitys. - Ympäristökonsultointi Jynx Oy, Littoinen. [https://kurikka.fi/wp-content/uploads/2019/06/Ponsivuori_Liite_02_Luontoselvitys.pdf].

*Yrjölä, R., Häyhä, T. Kyheröinen, E.-M., Santaharju, J. 2005: Luontoselvitys Espoon Miilukorven ja Pitkäniityn asemakaava-alueelta. - Espoon kaupunkisuunnittelukeskuksen julkaisuja. [https:/www.espoo.fi/download/ noname/\%7B30D3481 A-4327-4590-8425-FCF0D86D8B50\%7D/91066].

*Yrjölä, R., Hagner-Wahlsten, N., Häyhä, T. \& Kyheröinen, E.-M. 2006: Espoon Nuuksion eteläosan luontoselvitys 2005. - Espoon ympäristökeskuksen julkaisu 1/2006.

*Yrjölä, R., Helminen, S.-L. \& Hagner-Wahlsten, N. 2008: Kalastajantien länsipuolen luontoselvitykset 2008. — Ympäristötutkimus Yrjölä Oy, Klaukkala. [https:// www.espoo.fi/download/noname/\%7BA9E70859-5F3F41DE-82E3-ECCAB065E203\%7D/94227].

*Yrjölä, R., Santaharju, J., Helminen, S.-L. \& Hagner-Wahlsten, N. 2008: Gräsanojan luontoselvitykset 2008. Ympäristötutkimus Yrjölä Oy, Klaukkala. [https://www. espoo.fi/download/noname/\%7BB70BB8B4-2A99-4D1 F-A377-77C6E1056639\%7D/13641].

*Yrjölä, R., Helminen, S.-L., Hyytiäinen, R. \& Virtanen, T. 2011: Sammalvuori, Espoo luontoselvitykset 2011. — Ympäristötutkimus Yrjölä Oy, Helsinki. [https:// www.espoo.fi/download/noname/\%7B5EA51C28-17644FB4-B46C-70424DA110DF\%7D/16611].

*Yrjölä, R., Hyytiäinen, R., Helminen, S.-L., Friman, M., Hagner-Wahlsten, N. \& Tverin, M. 2011: Metsämaa-Odilampi, Espoo luontoselvitykset 2011. - Ympäristötutkimus Yrjölä Oy, Helsinki. [https://www.espoo.fi/download/ noname/\%7BD96F4A44-975E-4B72-92A3-D9FC1E2C05DA\%7D/17901. 